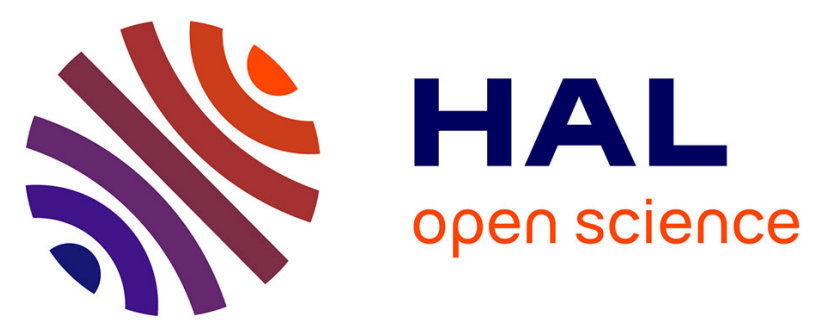

\title{
Design of P-Chirogenic Aminophosphine-Phosphinite (AMPP*) Ligands at both Phosphorus Centers: Origin of Enantioselectivities in Pd-Catalyzed Allylic Reactions
}

Antonin Jaillet, Christophe Darcel, Jérôme Bayardon, Adrien Schlachter, Christine Salomon, Yoann Rousselin, Pierre D Harvey, Sylvain Jugé

\section{To cite this version:}

Antonin Jaillet, Christophe Darcel, Jérôme Bayardon, Adrien Schlachter, Christine Salomon, et al.. Design of P-Chirogenic Aminophosphine-Phosphinite (AMPP*) Ligands at both Phosphorus Centers: Origin of Enantioselectivities in Pd-Catalyzed Allylic Reactions. Journal of Organic Chemistry, 2020, 85 (22), pp.14391-14410. 10.1021/acs.joc.0c00536 . hal-02635117

HAL Id: hal-02635117

https://hal-univ-rennes1.archives-ouvertes.fr/hal-02635117

Submitted on 28 May 2020

HAL is a multi-disciplinary open access archive for the deposit and dissemination of scientific research documents, whether they are published or not. The documents may come from teaching and research institutions in France or abroad, or from public or private research centers.
L'archive ouverte pluridisciplinaire HAL, est destinée au dépôt et à la diffusion de documents scientifiques de niveau recherche, publiés ou non, émanant des établissements d'enseignement et de recherche français ou étrangers, des laboratoires publics ou privés. 


\title{
Design of P-Chirogenic Aminophosphine-Phosphinite
}

\section{(AMPP*) Ligands at both Phosphorus Centers: Origin of}

\section{Enantioselectivities in Pd-Catalyzed Allylic Reactions}

\author{
Antonin Jaillet, a§ Christophe Darcel, ${ }^{\mathrm{b}}$ Jérôme Bayardon, a Adrien Schlachter, c Christine \\ Salomon, å Yoann Rousselin, a Pierre Harvey, and Sylvain Jugé*a
}

a Université de Bourgogne-Franche-Comté, Institut de Chimie Moléculaire (ICMUB-OCS, UMR-CNRS 6302), BP 47870, 21078 Dijon Cedex, France

b Université de Rennes, Institut des Sciences Chimiques de Rennes (ISCR, UMR-CNRS 6626), 35000 Rennes, France

c Université de Sherbrooke, Département de Chimie, Sherbrooke, Québec, Canada J1K2R1 
RECEIVED DATE (to be automatically inserted after your manuscript is accepted if required according to the journal that you are submitting your paper to)

\section{CORRESPONDING AUTHOR FOOTNOTE}

[*] To whom correspondence should be addressed. -mail: sylvain.juge@u-bourgogne.fr, Tel: +33 (0)3 80396113 .

\section{TABLE OF CONTENTS/ABSTRACT GRAPHIC}

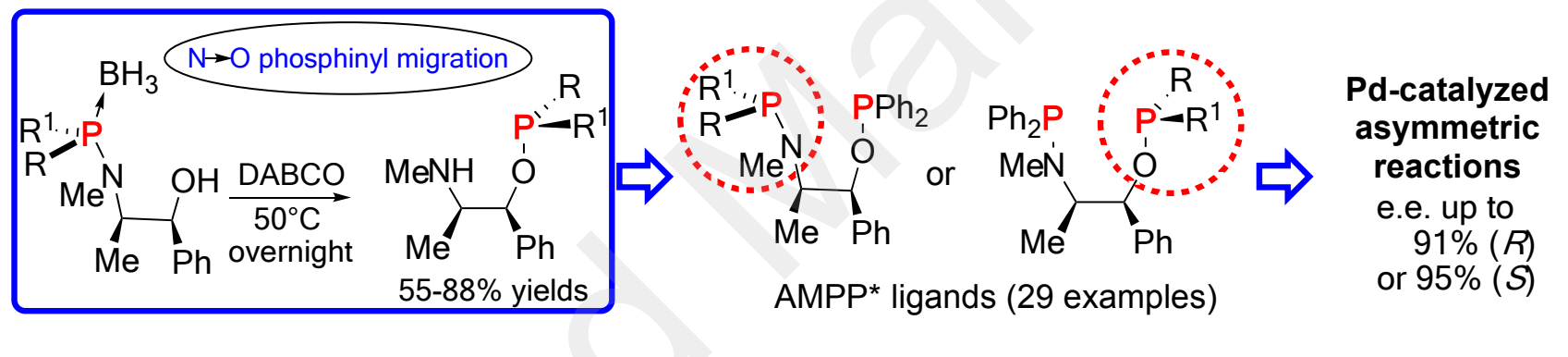

\section{ABSTRACT}

We have recently patented an unprecedented stereospecific $\mathrm{N} \rightarrow \mathrm{O}$ phosphinyl migration process which transforms P-chirogenic aminophosphines into phosphinites. A fine design of aminophosphine phosphinite ligands (AMPP*) derived from ephedrine and bearing a Pchirogenic center either at the aminophosphine or phosphinite moiety, was performed. The synthesis of AMPP* ligands with P-chirogenic aminophosphine moiety was based on the well-established stereospecific reaction of oxazaphospholidine-borane with organolithium 
reagents, followed by trapping with a chlorophosphine and borane decomplexation. Concurrently, the preparation of AMPP* ligands with P-chirogenic phosphinite moiety were performed by $\mathrm{N} \rightarrow \mathrm{O}$ phosphinyl migration of aminophosphines borane by heating at $50{ }^{\circ} \mathrm{C}$ with $\mathrm{DABCO}$, and then reaction with chlorophosphines. AMPP* ligands were studied in palladium-catalyzed asymmetric allylic alkylations, leading to enantioselectivities from $91 \%$ $(R)$ to $95 \%$ e.e. $(S)$. X-ray crystallographic data for relevant Pd-AMPP* complexes and computer modeling explained the origin of the enantioselectivities based on MO interactions of most stable conformers with nucleophiles.

\section{KEYWORDS}

P-Chirogenic ligands / Asymmetric catalysis / Palladium / Allylic substitution / Aminophosphine-phosphinites / Phosphorus rearrangement/ DFT-computation

\section{INTRODUCTION}

The chirality in phosphines used in enantioselective metal-catalyzed or organocatalyzed reactions has overwhelmingly been located on the carbon skeleton. ${ }^{1-3}$ If the efficiency of P-chirogenic ligands is also documented, ${ }^{4}$ the design of chiral ligands at the phosphorus centers has largely been neglected due to the lack of versatile methods to 
efficiently design series of catalysts and to obtain their enantiopure stereoisomers. Although the use of P-chirogenic compounds in organocatalyzed asymmetric reactions is also known for several decades, ${ }^{3}$ their applications also recently increased significantly. ${ }^{5}$ Consequently and unsurprisingly, the design of P-chirogenic compounds (and not only phosphines) is still a very active research area for the development of enantioselective catalyzed reactions. So far, the stereoselective synthesis of P-chirogenic organophosphorus compounds was usually achieved by $\mathrm{P}-\mathrm{C}$ bond formation. This was done using a limited number of P-chirogenic tetracoordinated building blocks, such as $t$ butylmethylphosphine-borane, secondary phosphine-oxide or phosphinous-borane derivatives. $^{4}$

Chiral aminophosphine phosphinites (AMPP) such as 1-8, represent a large family of readily available bidendate ligands in asymmetric catalysis (Chart 1). ${ }^{6}$ These ligands are obtained from the reaction between two equivalents of $\mathrm{Ph}_{2} \mathrm{PCl}$ or $(c \text {-pent })_{2} \mathrm{PCl}$ with commercially available amino alcohols such as ephedrine, threoninol, ${ }^{7 \mathrm{a}}$ prolinol, ${ }^{\mathrm{7b}}$ valinol, ${ }^{7 \mathrm{c}}$ propranolol, $^{7 \mathrm{~d}} \quad$ 1,2-diphenyl aminoethanol, ${ }^{7 \mathrm{e}, \mathrm{f}} \quad$ 2-indoline-methanol ${ }^{7 \mathrm{~g}, \mathrm{~h}} \quad$ or azabicyclo[2.2.1]hept-3-ylmethanol. ${ }^{7 i}$ AMPP ligands 2-8 are excellent for the asymmetric hydrovinylation of cyclohexadiene, ${ }^{7 \mathrm{a}}[2+2+2]$ cycloaddition, ${ }^{7 \mathrm{~b}, \mathrm{c}}$ hydrogenation of $\mathrm{C}=\mathrm{C}^{7 \mathrm{~d}-\mathrm{f}, \mathrm{i}}$ or 
$\mathrm{C}=\mathrm{O},{ }^{7 g}, \mathrm{~h}$ respectively. Enantioselectivities up to $99 \%$ e.e. using $\mathrm{Ni}-$, Co- or $\mathrm{Rh}-$ based complexes have been reached.

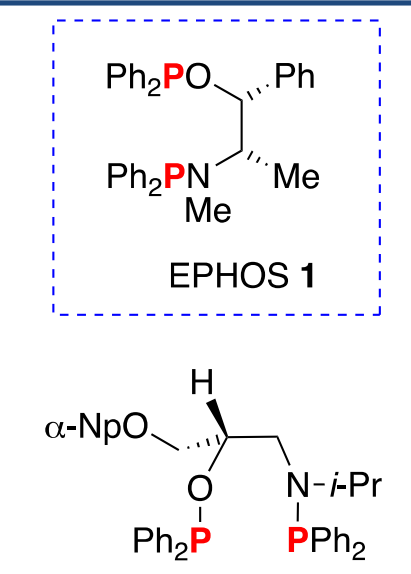

PROPRAPHOS 5<smiles>CC(OP)C(CO[PbH])C(C)N(C)Pc1ccccc1</smiles>

ThreoNOOP 2<smiles>CN(P)c1ccccc1</smiles>

DPAMPP 6<smiles>Pc1ccccc1</smiles>

ProNOP 3

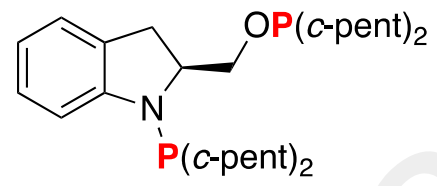
IndoNOP 7<smiles>CC(C)C(CO[PbH])C(=P)N(C)c1ccccc1</smiles>

ValNOP 4

\section{Chart 1. Representative Chiral Aminophosphine-Phosphinite (AMPP) ligands}

The EPHOS ligand 1 derived from (-)-ephedrine, described in pioneering works by B.

Petit and G. Buono, ${ }^{8 a}$ led to moderate enantioselectivities in asymmetric hydrogenation, ${ }^{8 \mathrm{~b}}$ hydroformylation, ${ }^{8 c, d}$ hydrosilylation ${ }^{8 \mathrm{e}}$ and allylation ${ }^{8 \mathrm{f}}$ catalyzed by Pt-, Rh- or Pd-complexes, respectively. During the past decade, we and Vogt group have independently described the synthesis of two series of modified EPHOS ligands 13 and 16 with P-chirogenic phosphorus centers (Scheme 1).9,10

Scheme 1. Stereoselective Synthesis of Modified EPHOS with P-chirogenic P-Centers 


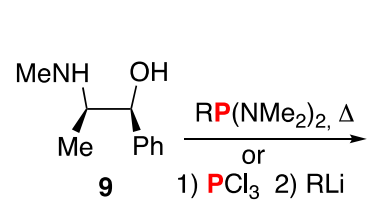

(+)-ephedrine then $\mathrm{BH}_{3}$

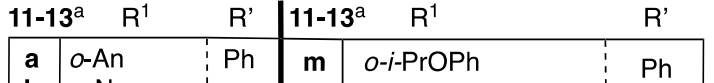

b $\alpha-N p$

c $\beta-\mathrm{Np}$

$\mathbf{d}^{\mathrm{b}} \quad 0$-Tol

\begin{tabular}{l|r}
$\mathbf{e}^{\mathrm{b}}$ & $p$-Tol \\
$\mathbf{f}$ & $o$-biPh
\end{tabular}

g $\mathrm{FC}$

h $t$-Bu

ic $^{\mathrm{Ph}}$

j $\mathrm{Me}$

k $c$-Hex

I o-MEMPh

R=o-biPh. d 2-[2',6'-(MeO)

e Prepared from (-)-ephedrine. ${ }^{f}$ Calix[4] ]arenyl. ${ }^{9}$ 1,1'-Binapht-2-yl

So far, a large series of P-chirogenic modified EPHOS ligands 13 (AMPP*) has been

synthesized from the oxazaphospholidine-borane $(-)-$ or $(+)-10$. They were derived from (+)- or (-)-ephedrine 9 based on a well-established methodology (Scheme 1). ${ }^{9,10}$ Thus, the borane complex $(-)-10$ reacted with organolithium reagents $\left(R^{1} L i\right)$ to afford the lithium salts [11] by a ring opening reaction upon $\mathrm{P}-\mathrm{O}$ bond cleavage. The salts [11] were successively trapped with a chlorophosphine $\mathrm{R}_{2}^{\prime} \mathrm{PCl}$ then with borane to produce the AMPP*-diborane complexes 12, and then isolated as air-stable and storable compounds (Scheme 1a). The free AMPP* 13 finally obtained after borane decomplexation of their corresponding diborane complexes 12 with DABCO, yielded up to $73 \%$ from ephedrine (Scheme 1a). This methodology permitted to synthesize numerous $\mathrm{P}$-chirogenic AMPP* ligands 13 with $\mathrm{R}^{1}=$ alkyl, cycloalkyl, aryl, bisaryl, heteroaryl or ferrocenyl and R' = phenyl-, $\alpha$-naphtyl- or 3,5- 
xylyl-substituents on the aminophosphine and phosphinite moieties, respectively (Scheme 1a). ${ }^{9,10}$ Similarly, the AMPP* ligands $13 \mathrm{u}-\mathbf{w}$ bearing o-biphenyl, calix[4]arenyl and 1,1'binaphth-2-yl substituents on the P-chirogenic aminophosphine moiety were prepared using the same methodology, but starting from (-)-ephedrine 9 (Scheme 2 and Supporting Information, $\mathrm{SI}) .{ }^{9 \mathrm{c}}$ For instance of their efficiency in asymmetric catalysis, the rhodium(I) complex with the P-chirogenic AMPP* 13a ligand bearing an o-anisyl group on the aminophosphine moiety (i.e. $\mathrm{R}^{1}=0$-An), efficiently promoted the asymmetric hydrogenation of dehydrophenylalanine with $99 \%$ e.e..$^{9 a}$ When the ring opened products [11] reacted with P-chirogenic chlorophosphine-boranes 14, the resulting AMPP*diboranes 15 were obtained with inversion of configuration at the phosphorus atom. After decomplexation by $\mathrm{DABCO}$, the free $\mathrm{P}$-chirogenic ligands 16 were diastereoselectively obtained with the chirality located on either the phosphinite or both aminophosphine and phosphinite moieties (Scheme 1b). ${ }^{9 a, b}$

However, the design of the phosphinite moiety in AMPP* 16 based on this methodology is limited. This is because the reaction of the products [11] with P-chirogenic chlorophosphine-boranes 14 bearing other substituents $R^{2}, R^{3}$ than $o$-anisyl, phenyl or methyl group was proven to be difficult (Scheme 1b). In this case, the reaction of the secondary alkoxide salts [11] with the chlorophosphine-boranes 14 led to epimeric AMPP* 
mixtures 16 with low yields due to the poor reactivity and the racemization of 14 in the medium (Scheme 1b). ${ }^{11}$

We have recently discovered an unexpected stereospecific intramolecular rearrangement of free $\mathrm{P}(\mathrm{III})$-chirogenic aminophosphine $\left\{\mathrm{R}^{1} \mathrm{R}^{2} \mathrm{PN}(\mathrm{R})-\mathrm{OH}\right\}$ derived from chiral 1,2aminoalcohols into their corresponding phosphinites $\left\{R^{1} R^{2} P O-N H(R)\right\} .{ }^{12} \quad$ This rearrangement obtained by stereospecific $\mathrm{N} \rightarrow \mathrm{O}$ phosphinyl migration, has been used for the synthesis of AMPP* ligands 20 bearing a P-chirogenic phosphinite moiety. As proof of the method efficiency, the stereoselective synthesis of four epimers of the o-biphenyl containing AMPP* ligands $13 \mathrm{f}, \mathrm{i}$ and $20 \mathrm{f}, \mathrm{i}$, was herein reported with $\left(R_{\mathrm{p}}\right)$ - or $\left(S_{\mathrm{p}}\right)$ configuration either on aminophosphine or phosphinite moieties. Finally, the P-chirogenic

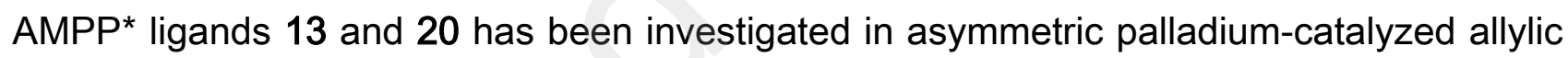
reactions and the resulting enantioselectivities ( $R$ or $S$ ), based on the P-chirality in the metal-sphere of coordination, were explained by DFT computations.

\section{RESULTS AND DISCUSSION}

Due to the atropoisomery of the binaphtyl substituent, the preparation of the AMPP* $13 v$ warrants a particular attention (Scheme 2). The synthesis was achieved by reacting oxazaphospholidine-borane (+)-10a (prepared from (-)-ephedrine) with the 1,1'-binaphth-2- 
yllithium reagent (prepared by a metal-halide exchange of ( \pm )-2-bromobinaphtyl 17 with $t$ BuLi), at $-78^{\circ} \mathrm{C}$ in THF (Scheme 2). The aminophosphine-borane $11 \mathrm{v}$ was obtained in $38 \%$ yield as a mixture of stereoisomers in $85: 15$ ratio. The major isomer of $11 \mathrm{v}$ was isolated by crystallisation in ethyl acetate and its structure was established by X-ray diffraction. This latter showed that the absolute configuration at the phosphorus center was $S_{p}$ when the atropoisomeric binaphtyl moiety was $M$ (see SI). The diastereoselectivity was explained by the dynamic resolution of the binaphtyllithium reagent during the reaction with the oxazaphospholidine-borane $(+)$-10a leading to the ring-opened product $11 \mathrm{v}$ (Scheme 2$).{ }^{13}$ The aminophosphine-borane $\left(M, S_{\mathrm{p}}\right)-11 \mathrm{v}$ was then deprotonated with $n$-BuLi at $-78^{\circ} \mathrm{C}$, to afford the corresponding alkoxide salt [11v] which was trapped with $\mathrm{Ph}_{2} \mathrm{PCl}$ then with borane to form the AMPP*-diborane complex $12 \mathrm{v}$ in $41 \%$ yield. The free diastereomerically pure $\operatorname{AMPP}^{\star}\left(M, S_{p}\right)-13 v$ was isolated in $85 \%$ yield after decomplexation of the diborane complex $12 \mathrm{v}$ upon heating with $\mathrm{DABCO}$ in toluene at $50{ }^{\circ} \mathrm{C}$ overnight, and purification on a neutral alumina column.

Scheme 2. Synthesis of P-chirogenic binaphtyl-AMPP* $\left(M, S_{\mathrm{p}}\right)-13 \mathrm{v}$

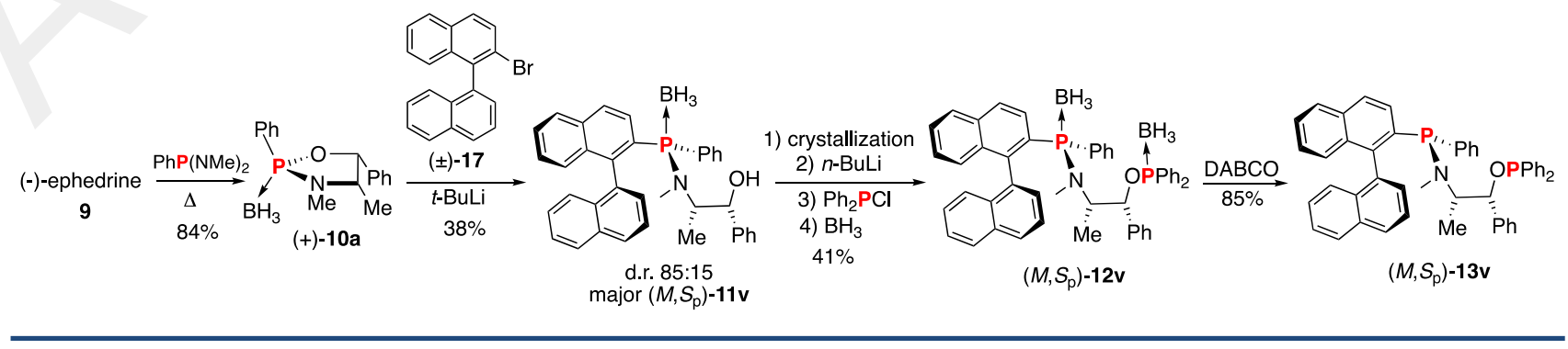


Concurrently, the synthesis of $\mathrm{AMPP}^{*}$ derivatives with the chirality located on the phosphinite moiety was achieved according to Scheme 3. The aminophosphine-boranes 11, resulting from the hydrolysis of their alkoxide salts [11], afforded the P-chirogenic aminophosphines 18 upon heating at $50^{\circ} \mathrm{C}$ in toluene overnight with two equivalents of DABCO. The aminophosphine 18 then led to the P-chirogenic phosphinite 19 by intramolecular $S_{N}$-like substitution resulting in $\mathrm{N} \rightarrow \mathrm{O}$ phosphinyl migration. ${ }^{12}$ This new rearrangement could also be achieved with 0.5 equivalent of DABCO. It proceeded with complete retention of configuration at the P-atom and was easily monitored by ${ }^{31} \mathrm{P} N M R$. The decomplexation of the aminophosphine-borane complex 11 into free aminophosphine 18, followed by the rearrangement into their corresponding phosphinites 19 , exhibited the disappearance and appearance of characteristic signals at $\approx+70,50$ and 110 ppm, respectively (Scheme 3).

Scheme 3. Synthesis of AMPP*s from Aminophosphines via $\mathrm{N} \rightarrow \mathrm{O}$ Phosphinyl Migration

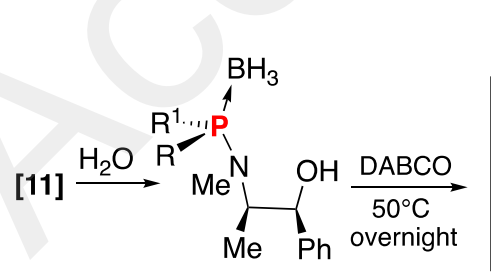

11

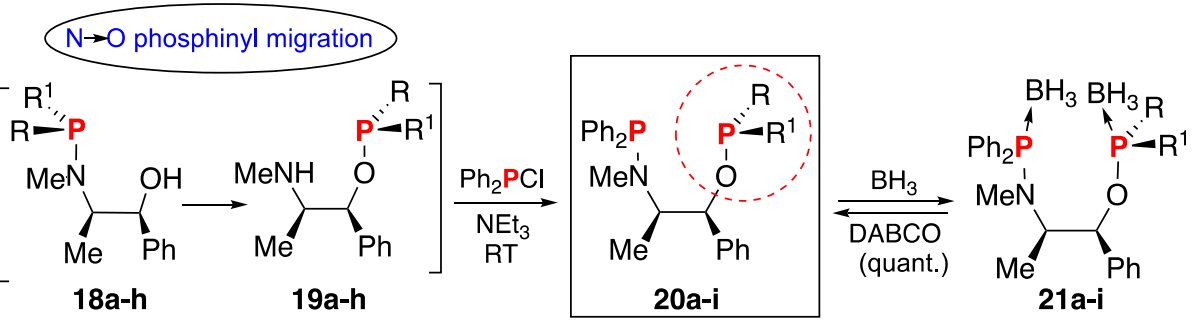

$$
\begin{array}{c|ccccccccc}
\mathbf{1 8 - 2 1} & \mathbf{a} & \mathbf{b} & \mathbf{c} & \mathbf{d} & \mathbf{e} & \mathbf{f} & \mathbf{g} & \mathbf{h} & \mathbf{i} \\
\hline \mathrm{R}^{1} & o-\mathrm{An} & \alpha-\mathrm{Np} & \beta-\mathrm{Np} & o-\mathrm{Tol} & \overline{-} \text {-Tol } & o-\text { biPh } & \mathrm{Fc} & t-\mathrm{Bu} & \mathrm{Ph} \\
\mathrm{R} & \mathrm{Ph} & \mathrm{Ph} & \mathrm{Ph} & \mathrm{Ph} & \mathrm{Ph} & \mathrm{Ph} & \mathrm{Ph} & \mathrm{Ph} & o \text {-biPh }
\end{array}
$$


The phosphinites 19 could be isolated either under a P-free form or after complexation with borane. They were directly used without purification for the synthesis of the AMPP* 20 bearing a P-chirogenic phosphinite moiety. They reacted with the chlorodiphenylphosphine in presence of triethylamine at room temperature (Scheme 3). The free AMPP* ligands 20 were isolated from the reaction medium, but they were usually complexed by boranedimethylsulfide and then stored as diborane complexes 21 (Scheme 3). The P-chirogenic AMPP* $^{*} 20$ were obtained as free ligands directly usable in asymmetric catalysis, in contrast with the synthetic method reported in Scheme 1 . AMPP* 20 , their ${ }^{31} \mathrm{P}$ NMR chemical shifts and their diborane complexes 21, are reported in Table 1.

\section{Table 1. Synthesis of AMPP* and Diborane Complexes with P-chirogenic Phosphinite} Moieties

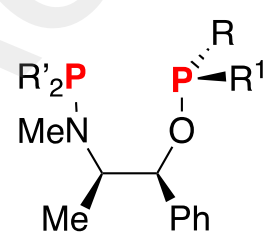

20a-i

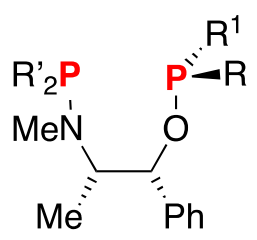

$\left(S_{\mathrm{P}}\right)-20 \mathrm{a}, \mathbf{b}$<smiles>[R5]P([B])[Pb][PH]([R7])([B])OC(c1ccccc1)C(C)N</smiles>

21a-i<smiles>[R7]N(C)C(C)C(O[P+]([R7])([B])P([R7])[B])c1ccccc1</smiles>

$\left(S_{P}\right)-21 \mathbf{a}, \mathbf{b}$ entry ephedrine

9
AMPP $^{*} 20$

$\mathrm{R}^{1}$
$\operatorname{AMPP}^{*}\left(\mathrm{BH}_{3}\right)_{2}{ }^{a}$

R'21 


\begin{tabular}{|c|c|c|c|c|c|c|c|c|}
\hline & & $\delta^{31} \mathrm{~Pb}^{\mathrm{b}}$ & & & & & $(\%)^{\mathrm{c}}$ & ield \\
\hline 1 & $(+)$ & $\left(R_{\mathrm{p}}\right)-20 \mathrm{a}$ & $o-A n$ & $\mathrm{Ph}$ & $\mathrm{Ph}$ & $\begin{array}{r}+64.4 \\
+100.5\end{array}$ & $\left(R_{\mathrm{p}}\right)-21 \mathrm{a}$ & 68 \\
\hline 2 & $(-)$ & $\left(S_{p}\right)-20 a$ & $o-A n$ & $"$ & " & $\begin{array}{r}+64.9 \\
+100.1\end{array}$ & $\left(S_{p}\right)-21 a$ & 65 \\
\hline 3 & $(+)$ & $\left(R_{\mathrm{p}}\right)-20 \mathrm{~b}$ & $\alpha-N p$ & $"$ & $"$ & $\begin{array}{r}+65.0 \\
+107.1\end{array}$ & $\left(R_{\mathrm{p}}\right)-21 \mathrm{~b}$ & 63 \\
\hline 4 & $(-)$ & $\left(S_{p}\right)-20 \mathrm{~b}$ & $\alpha-N p$ & $"$ & $"$ & $\begin{array}{c}+64.7 \\
+107.4\end{array}$ & $\left(S_{p}\right)-21 b$ & 61 \\
\hline 5 & $(+)$ & $\left(R_{\mathrm{p}}\right)-20 \mathrm{c}$ & $\beta-N p$ & $"$ & $"$ & $\begin{array}{r}+64.8 \\
+110.5\end{array}$ & $\left(R_{\mathrm{p}}\right)-21 \mathrm{c}$ & 81 \\
\hline 6 & $(+)$ & $\left(R_{\mathrm{p}}\right)-20 \mathrm{~d}$ & o-Tol & $"$ & $"$ & $\begin{array}{r}+64.7 \\
+104.7\end{array}$ & $\left(R_{\mathrm{p}}\right)-21 \mathrm{~d}$ & 65 \\
\hline 7 & $(+)$ & $\left(R_{\mathrm{p}}\right)-20 \mathrm{e}$ & $p$-Tol & $"$ & $"$ & $\begin{array}{r}+64.5 \\
+112.5\end{array}$ & $\left(R_{\mathrm{p}}\right)-21 \mathrm{e}$ & 67 \\
\hline 8 & $(+)$ & $\left(R_{\mathrm{p}}\right)-20 \mathrm{f}$ & o-biPh & $"$ & $"$ & $\begin{array}{r}+64.9 \\
+101.9\end{array}$ & $\left(R_{\mathrm{p}}\right)-21 \mathrm{f}$ & 67 \\
\hline 9 & $(+)$ & $\left(R_{\mathrm{p}}\right)-20 \mathrm{~g}$ & Fc & " & " & $\begin{array}{l}+64.7 \\
+105.5\end{array}$ & $\left(R_{\mathrm{p}}\right)-21 \mathrm{~g}$ & 68 \\
\hline 10 & $(+)$ & $\left(S_{p}\right)-20 h$ & $t$-Bu & $"$ & " & $\begin{array}{c}+66.4 \\
+129.4\end{array}$ & $\left(S_{p}\right)-21 h$ & 59 \\
\hline 11 & $(+)$ & $\left(S_{p}\right)-20 \mathrm{i}$ & $\mathrm{Ph}$ & o-biPh & " & $\begin{array}{c}+65.1 \\
+104.8\end{array}$ & $\left(S_{p}\right)-21 \mathrm{i}$ & 58 \\
\hline
\end{tabular}

${ }^{a}$ Isolated yield from aminophosphine-borane 11. ${ }^{\mathrm{b}} \delta$ in ppm. ${ }^{\mathrm{c}}$ Diastereoselectivity (> 99\%) checked by NMR.

The o-anisyl-aminophosphine-borane $11 a\left(R^{1}=o-A n, R=P h\right)$, prepared from $(+)-$ ephedrine, afforded the $o$-anisylphosphinite $19 \mathrm{a}$ upon heating at $50^{\circ} \mathrm{C}$ overnight with two equivalents of DABCO in toluene. It reacted with $\mathrm{Ph}_{2} \mathrm{PCl}$ in presence of $\mathrm{NEt}_{3}$ to provide the free $\operatorname{AMPP}^{*}\left(R_{\mathrm{p}}\right)-20 \mathrm{a}$ (Table 1, entry 1$)$. The $\operatorname{AMPP}^{*}\left(S_{\mathrm{p}}\right)-20 \mathrm{a}$ was similarly synthesized 
from (-)-ephedrine 9 (entry 2). These AMPP* were characterized by their ${ }^{31} \mathrm{P} N M R$ chemical shifts at $\sim+64$ and +100 ppm, corresponding to their trivalent aminophosphine and phosphinite moieties. They were isolated after addition of $\mathrm{BH}_{3}$. DMS as diborane complexes $\left(R_{\mathrm{p}}\right)$ - or $\left(\mathcal{S}_{\mathrm{p}}\right)-21 \mathrm{a}$ in 68 or $65 \%$ yield, respectively (entries 1,2 ). The diastereoselectivity (> 99\%) was checked by NMR analysis of the free AMPP* 20a and its diborane complex 21a. The free P-chirogenic ligands 20a could be recovered by borane decomplexation of 21 a with DABCO (Scheme 3 ). In addition, the $\alpha$ - or $\beta$-naphtyl-, $o$ - or $p$ tolyl-, o-biphenyl-, ferrocenyl- and $t$-butylphenylphosphinites $19 \mathrm{~b}$-i were obtained from the rearrangement of their corresponding aminophosphine-boranes $11 \mathrm{~b}-\mathrm{i}$ previously prepared from (+)-ephedrine 9. Finally, the reaction of the phosphinite-boranes $19 \mathrm{~b}-\mathrm{i}$ with $\mathrm{Ph}_{2} \mathrm{PCl}$ in presence of $\mathrm{NEt}_{3}$ and then complexation with $\mathrm{BH}_{3}$.DMS, led to the AMPP*-diborane complexes $21 \mathrm{~b}$-i in yields up to $81 \%$ (entries $3-11$ ).

The X-ray crystal structures of eight AMPP*-diborane complexes 21a-h have been solved. Their absolute configurations are reported in SI (Figures S8 to S16). Consequently, as the borane complexation and decomplexation proceed with retention of configuration at the P-atom, the resulting stereochemistry of the AMPP* 20 from aminophosphine-borane 11 is consistent with the retention during the $\mathrm{N} \rightarrow \mathrm{O}$ phosphinyl migration step (Scheme 3). The ORTEP views of all AMPP*-diborane complexes 12, 15 or 21 exhibited similar aspects 
of unfolded conformations of the chain, flattened geometries for the amino groups, and anti orientation of the P-B bonds with P1-B1-P2-B2 dihedral angles up to $165^{\circ}$ (Figures S4 to S16, SI).

The efficiency of the method was demonstrated by the stereoselective synthesis of all $\left(R_{\mathrm{p}}\right)$ - and $\left(S_{\mathrm{p}}\right)$-epimers of the free o-biphenyl-containing AMPP* ligands $13 \mathrm{f}, \mathrm{i}$ and $20 \mathrm{f}, \mathrm{i}$, bearing a P-chirogenic center either at the aminophosphine or phosphinite moiety. These epimers were prepared from the oxazaphospholidine-borane complexes (-)-10a and (-)10b derived from (+)-ephedrine 9 (Scheme 4). The latter complex (-)-10b was prepared in a diastereomerically pure form according to a modified litterature procedure. ${ }^{14,15}$ It uses successive reactions of (+)-ephedrine 9 with $\mathrm{PCl}_{3}$, then with 0 -biphenyllithium reagent and finally with $\mathrm{BH}_{3} \cdot \mathrm{DMS}$ for complexation (Scheme 4).

Scheme 4. Diastereodivergent Synthesis of P-chirogenic AMPP* bearing an o-biphenyl Group

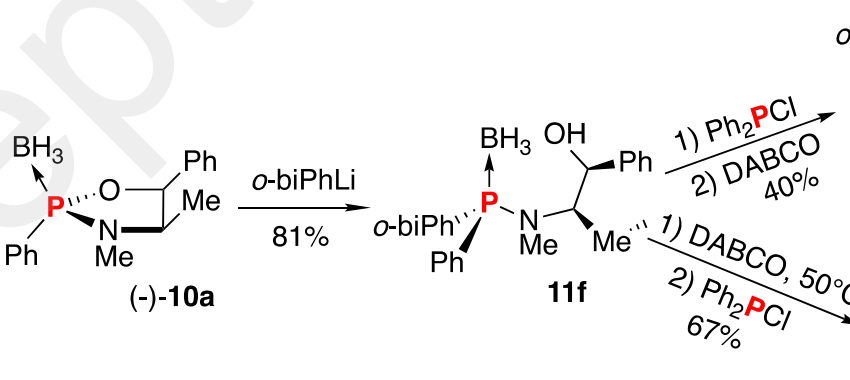
$\mathrm{Ph}-\mathrm{P}$ - $\mathrm{PPPh}_{2}$

(+)-ephedrine 9<smiles>COC(c1ccccc1)C(C)N(C)C</smiles>

$\left(R_{\mathrm{p}}\right)-13 f$<smiles>CN(C)P(=P)(OO[Pb](c1ccccc1)c1ccccc1)c1ccccc1</smiles>

$\left(R_{\mathrm{p}}\right)-20 f$

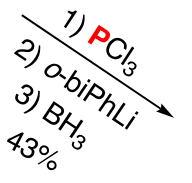

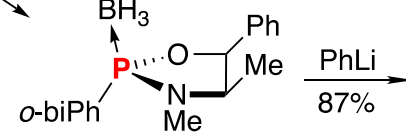

$(-)-10 b$

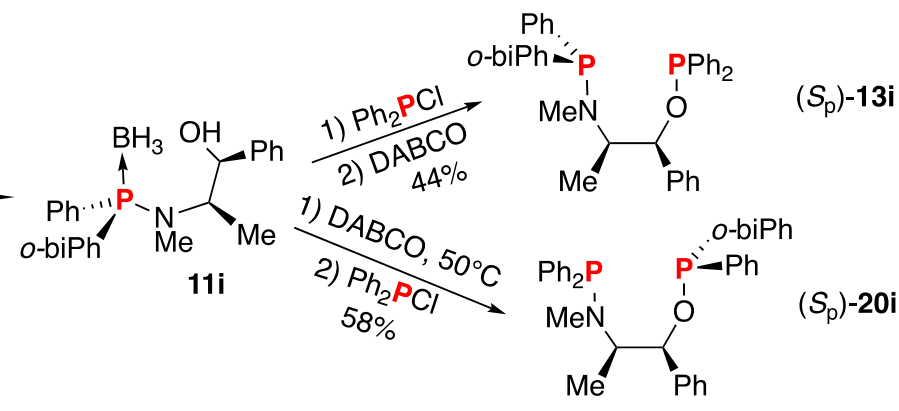

\section{.}


Oxazaphospholidine complex (+)-10a reaction with the o-biphenyllithium reagent led first to the $\left(R_{\mathrm{p}}\right)$-aminophosphine-borane $11 \mathrm{f}$ in $81 \%$ yield (Scheme 4$)$. This latter was reacted with $\mathrm{Ph}_{2} \mathrm{PCl}$ either directly followed by decomplexation, or after rearrangement upon heating with DABCO to afford the free P-chirogenic $\mathrm{AMPP}^{*}\left(R_{\mathrm{P}}\right)-13 \mathrm{f}$ or $\left(R_{\mathrm{P}}\right)-20 \mathrm{f}$ in $40 \%$ and $67 \%$ yields, respectively (Scheme $4 a, b$ ). The X-ray structures of the diborane complexes $\left(R_{\mathrm{p}}\right)-12 \mathrm{f}$ and $\left(R_{\mathrm{p}}\right)-21 \mathrm{f}$ of the $\mathrm{AMPP}^{*}\left(R_{\mathrm{P}}\right)-13 \mathrm{f}$ and $\left(R_{\mathrm{p}}\right)-20 \mathrm{f}$, are showed in Figures S4 and S14 (SI). Concurrently, the oxazaphospholidine complex (-)-10b reacted with the phenyllithium reagent to form the $\left(S_{p}\right)$-aminophosphine-borane $11 \mathrm{i}$ with a yield of $87 \%$ (Scheme 4). The reaction of $11 \mathrm{i}$ with $\mathrm{Ph}_{2} \mathrm{PCl}$ followed by decomplexation, or after rearrangement upon heating with $\mathrm{DABCO}$, led to the free $\operatorname{AMPP}^{*}\left(S_{\mathrm{P}}\right)-13 \mathbf{i}$ and $\left(S_{\mathrm{P}}\right)-20 \mathrm{i}$ with respective yield of $44 \%$ and $58 \%$ (Scheme 4c,d). Figure S6 (SI) shows the X-ray structure of the borane complexes $\left(S_{p}\right)-12 \mathbf{i}$ of P-chirogenic $\operatorname{AMPP}^{*}\left(S_{p}\right)-13 \mathbf{i}$, bearing an epimeric $o$ biphenyl-aminophosphine moiety in relation to $\left(R_{\mathrm{P}}\right)-13 \mathrm{f}$.

The P-chirogenic AMPP* ligands bearing P-chirogenic aminophosphine 13 or phosphinite moieties 20 were studied in palladium-catalyzed allylic reactions of dimethyl malonate and benzylamine (vide infra). The palladium-catalyzed asymmetric allylic 
alkylation led to many elegant applications in organic synthesis and the fine design of efficient chiral ligands is still topical. ${ }^{16,17}$ This asymmetric catalysis proceeds by nucleophilic attacks to the $\pi$-allylic moiety formed upon complexation to palladium, which led Trost group to develop efficient pocket-shaped ligands supported by a chiral 1,2-diamine bridge. ${ }^{16}$ Although P-chirogenic ligands, such as 22 to 26 , led also to highly enantioselective allylic catalyzed allylation with e.e. $>95 \%,{ }^{18-22}$ the design of phosphines at the P-centers for this reaction was rarely performed and few structural elements allowed the prediction of their stereoselectivity (Chart 2). This outcome could be explained by a limited level of understanding of the influence of chirality located on the P-atoms on the environment of the $\pi$-allylic moiety. Given the homochirality of the twenty nine P-chirogenic AMPP* 13 and 20 synthesized herein, they were investigated in Pd-catalyzed allylic alkylation reactions. This was to determine the relationship between their structure and the enantioselectivity $(R)$ or $(S)$ obtained.

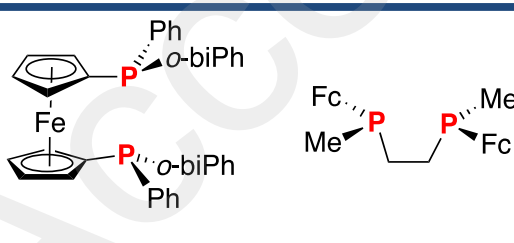

22

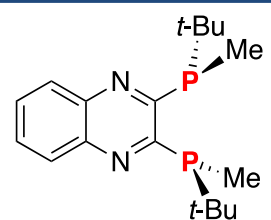

24

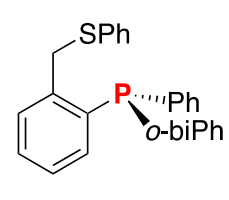

25

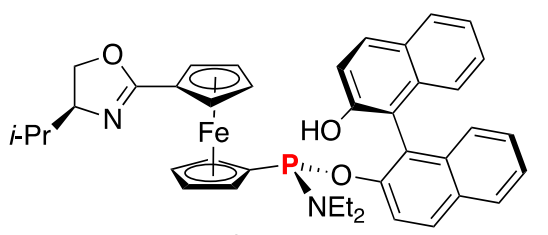

26

Chart 2. Representative P-chirogenic Phosphorus Ligands used in Pd-catalyzed Asymmetric Allylic Alkylation 
The allylation reaction of dimethyl malonate was first examined with the allylic substrate 27, using 1-2 mol\% of $\left[\mathrm{Pd}\left(\mathrm{C}_{3} \mathrm{H}_{5}\right) \mathrm{Cl}\right]_{2}$ and 2-4 mol\% of AMPP* 13 or 21 as in situ generated catalyst, in the presence of 2 equiv. of $N, O$-bis(trimethylsilyl)acetamide (BSA) in dichloromethane, and a catalytic amount of potassium acetate as base (Tables 2 and 3). According to the $\mathrm{AMPP}^{*}$ used, the reactions were usually completed within 1 to $48 \mathrm{~h}$ at room temperature to afford the mono allylated malonate 28 , in isolated yields up to $92 \%$ (Table 2). The dependence of the reaction conditions on the allylation showed a moderate effect on the enantioselectivity (see SI).

The catalyzed allylic substitution of the $(E)$-1,3-diphenylprop-2-en-1-yl acetate 27 by palladium AMPP* complexes, was also investigated using benzylamine as the nucleophile. The reactions were performed at room temperature in dichloromethane, using TBAF as base, affording the corresponding allylated benzylamine 29 in $7 \mathrm{~h}$. The results on the catalyzed asymmetric allylations using the P-chirogenic AMPP* 13 and 21 are respectively summarized in Tables 2 and 3.

\section{Table 2. Asymmetric Allylation of Dimethylmalonate and Benzylamine Catalyzed by Palladium Complexes of AMPP*13}




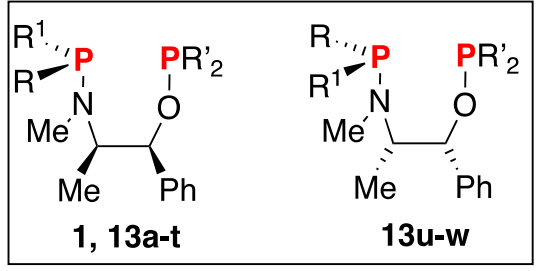

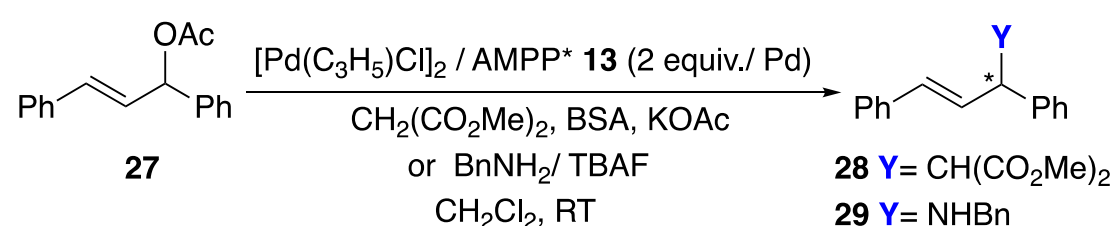

entry $\quad$ P-chirogenic AMPP* ligand $13 \quad$ product $28 \quad$ product 29

$\mathrm{R}^{1}$

R R' Yield ee abs. Yield ee abs.

$(\%)^{\mathrm{a},}(\%)^{\mathrm{c}}$ conf. $(\%)^{\mathrm{a}, \mathrm{d}}(\%)^{\mathrm{c}}$ conf.

1 EPHOS 1

$2\left(R_{\mathrm{p}}\right)-13 \mathrm{a}$

$3\left(R_{\mathrm{p}}\right)-13 \mathrm{~b}$

$4 \quad\left(R_{\mathrm{p}}\right)-13 \mathrm{c}$

$5 \quad\left(R_{\mathrm{p}}\right)-13 \mathrm{f}$

$6 \quad\left(R_{\mathrm{p}}\right)-13 \mathrm{~g}$

$7 \quad\left(S_{p}\right)-13 h$

$8 \quad\left(S_{\mathrm{p}}\right)-13 \mathbf{i}$

$9 \quad\left(S_{\mathrm{p}}\right)-13 \mathrm{j}$

$10 \quad\left(S_{p}\right)-13 k$

$11\left(R_{\mathrm{p}}\right)-13 \mathrm{I}$

$12\left(R_{\mathrm{p}}\right)-13 \mathrm{~m}$

$13\left(R_{\mathrm{p}}\right)-13 \mathrm{n}$

$14\left(R_{\mathrm{p}}\right)-130$

$15\left(R_{\mathrm{p}}\right)-13 \mathrm{p}$

$16\left(R_{\mathrm{p}}\right)-13 \mathrm{q}$

3,5-di(t-Bu)-4-

$\mathrm{MeOPh}$

$17\left(R_{\mathrm{p}}\right)-13 \mathrm{r}$

$18 \quad\left(R_{\mathrm{p}}\right)-13 \mathrm{~s} \quad 2-\left(2^{\prime}, 6^{\prime}-\mathrm{diMeO}\right) \mathrm{biPh}$

$19\left(R_{\mathrm{p}}\right)-13 \mathrm{t}$

o-biPh

$20\left(S_{\mathrm{p}}\right)-13 \mathrm{u}^{\mathrm{g}}$

Calix

$21\left(M, S_{p}\right)-13 v^{g}$

2-biNp

$22\left(S_{p}\right)-13 w^{g}$

o-biPh b

$\mathrm{Ph} \quad \mathrm{Ph} \quad-\quad 42^{\mathrm{e}} \quad(S) \quad 90 \quad 27 \quad(R)$

$\begin{array}{lllllll}\mathrm{Ph} & \mathrm{Ph} & 90 & 62 & \text { " } & 86 & 33\end{array}$

$87 \quad 44$

$74 \quad 38$

$92 \quad 82$

$89 \quad 80$

$(R)$

$\begin{array}{llllll}83 & 70 \quad \text { " } & 91 & 56 & (R)\end{array}$

$8341 \quad(R)$

$\begin{array}{lllll}91 & 91 & (R) \quad 89 \quad 95\end{array}$

$88 \quad 41 \quad(S)$

$66 \quad 61$

$86 \quad 55$

$70 \quad 36$

\begin{tabular}{ll}
$70 \quad 34$ \\
\hline
\end{tabular}

$\begin{array}{ll}74 & 8\end{array}$

$82 \quad 38$

$74 \quad 39$

$71 \quad 43$

$86 \quad 28 \quad(R)$

$\alpha-N p \quad 82 \quad 70$

$\begin{array}{lll}\mathrm{Ph} & 87 & 27\end{array}$

$\begin{array}{lll}\mathrm{Ph} & 84 & 81\end{array}$

3,5-Xyl $84 \quad 85$ 
a Reactions were carried out in $\mathrm{CH}_{2} \mathrm{Cl}_{2}([27]=0.3 \mathrm{M})$ with 1-2 mol\% of $\left[\mathrm{Pd}\left(\mathrm{C}_{3} \mathrm{H}_{5}\right) \mathrm{Cl}\right]_{2}$ and 2-4 mol\% of AMPP* 13, 2 equiv. of dimethyl malonate or benzylamine as nucleophile, 2 equiv. of $N, O$-bis(trimethylsilyl)acetamide (BSA) and a catalytic amount of KOAc (10 mol\%) or 2 equiv. of TBAF as base, respectively. ${ }^{b}$ The reaction was performed to completion in 1 to $48 \mathrm{~h}$. ${ }^{c}$ Determined by HPLC on chiral column. ${ }^{d}$ Reaction time $7 \mathrm{~h} .{ }^{\mathrm{e}}$ Reference 8f. ${ }^{f}$ Test not realized. ${ }^{g}$ Prepared from (-)-ephedrine 9.

EPHOS ligand $1\left(R^{1}, R, R^{\prime}=P h\right)$ bearing achiral aminophosphine and phosphinite moieties used in the Pd-catalyzed asymmetric allylation of malonate and benzylamine, exhibited moderate enantioselectivities of $42 \%$ af and $27 \%$ e.e. for products (S)-28 and (R)29, respectively (Table 2, entry 1). In contrast, the enantioselectivities of the catalyzed reactions exhibited a strong substituent-dependence of the P-chirogenic EPHOS ligands 13, as the allylated products 28 and 29 with $(S)$ - or $(R)$-configurations were obtained with enantioselectivities up to $95 \%$ (entry 8). However, when the AMPP* ligands 13 derived from $(+)$-ephedrine bore $\mathrm{R}^{1}=o$-An, $\alpha-\mathrm{Np}, \beta-\mathrm{Np}, \mathrm{Fc}, \mathrm{Me}, c$-Hex, o-MEMPh, $\alpha-$ - PrOPh, $\alpha$ BnOPh, 3,5-Xyl, 3,5-di(t-Bu)Ph, 3,5-di(t-Bu)-4-MeOPh or 2-Pyr on the aminophosphine moiety, the allylated methyl malonate (S)-28 were obtained with $8-70 \%$ e.e. (entries $2-4,6$, 9-17). In the case of AMPP* $13 \mathrm{u}$ linked at the upper-rim to a calix[4]arene unit, the catalyzed allylic alkylation also led to a low enantioselectivity ( $27 \%$ e.e.; entry 20$)$. On the 
other hand, when the catalyzed allylation was performed with the AMPP* $13 \mathrm{~h}$ or $13 \mathrm{~s}$ prepared from $(+)$-ephedrine 9 and bearing $t$-butyl or 2-(2',6'-dimethoxy)biphenyl as $\mathrm{R}^{1}$ substituent, the observed enantioselectivities were reversed and $(R)-28$ was obtained with 41 and $28 \%$ e.e., respectively (entries 7,18 ). When the aminophosphine arm of the AMPP* ligands 13 bore a binaphtyl or a biphenyl substituent, the enantioselectivities were strikingly enhanced. Thus, the binaphtyl $\operatorname{AMPP}^{*}\left(M, S_{p}\right)-13 v$, derived from (-)-ephedrine 9 , was used in the palladium-catalyzed asymmetric allylation of the dimethyl malonate, the product $(R)$ 28 was obtained with $81 \%$ e.e. (entry 21 ). Using the ligand AMPP* $13 f$ derived from $(+)-$ ephedrine 9 and bearing an 0 -biphenyl as $R^{1}$ substituent, the palladium catalysed reaction afforded the allylated malonate derivative (S)-28 with $82 \%$ e.e. (entry 5). Surprisingly, when the phenyl- of diphenylphosphinite moiety of AMPP* $13 f$ was replaced by a $\alpha$ naphtyl- or a 3,5-xylyl- group, the corresponding AMPP* $13 t$ and $13 w$ exhibited a modest change of the enantioselectivities. This was because the asymmetric catalyzed allylation were achieved with $70 \%$ and $85 \%$ vs $82 \%$ e.e., respectively (entries 5, 19 and 22). Interestingly, the $\operatorname{AMPP}^{*}\left(S_{p}\right)$-13i derived from (+)-ephedrine 9 and bearing an 0 -biphenyl substituent at the aminophosphine moiety as $\mathrm{R}$ group, led to the allylated product $(R)-28$ with $91 \%$ e.e. (entry 8 ). In this latter case, the product 28 was obtained with a reversed absolute configuration upon using the epimeric o-biphenyl AMPP* ligand $\left(R_{\mathrm{p}}\right)-13 \mathrm{f}$. This 
illustrates the key importance of the P-chirality at the aminophosphine moiety on the enantioselectivity of the catalytic transformation (82\% e.e. $(S)$ vs $91 \%$ e.e. $(R)$; entries 5 and 8$).{ }^{23}$

The AMPP* ligands $13 \mathrm{a}$ and $13 \mathrm{~g}$ bearing o-anisyl or ferrocenyl as $\mathrm{R}^{1}$ substituents at the aminophosphine moiety, also enhanced the enantioselectivity with respect to EPHOS 1 (Table 2, entry 1), for the Pd-catalyzed allylation using benzylamine. In these case, the product $(R)-29$ was obtained with 33 and $56 \%$ e.e., respectively (entries 2 and 6). The epimeric AMPP* ligands $\left(R_{\mathrm{p}}\right)-13 \mathrm{f}$ and $\left(S_{\mathrm{p}}\right)$-13i bearing an 0 -biphenyl group either as $\mathrm{R}^{1}$ or $\mathrm{R}$ on the aminophosphine moiety, remarkably, led to the allylated benzylamine 29 with an opposite absolute configuration and with e.e. up to $95 \%$ (entries 5 and 8 ). ${ }^{23}$ Results obtained for the catalyzed allylation of dimethyl malonate and benzylamine using palladium complexes derived from AMPP* 20 bearing a P-chirogenic phosphinite moiety, are reported in Table 3.

\section{Table 3. Asymmetric Allylation of Dimethylmalonate and Benzylamine Catalyzed Palladium}

\section{Complexes of AMPP* 20}
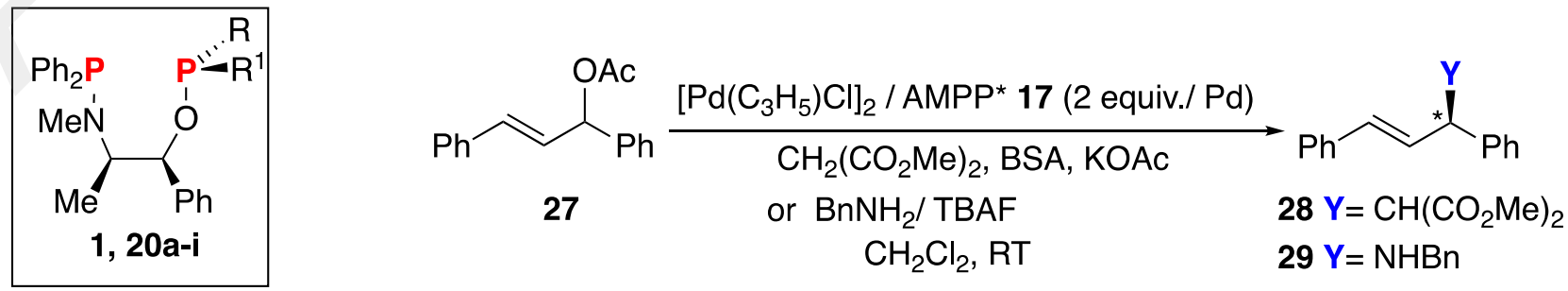


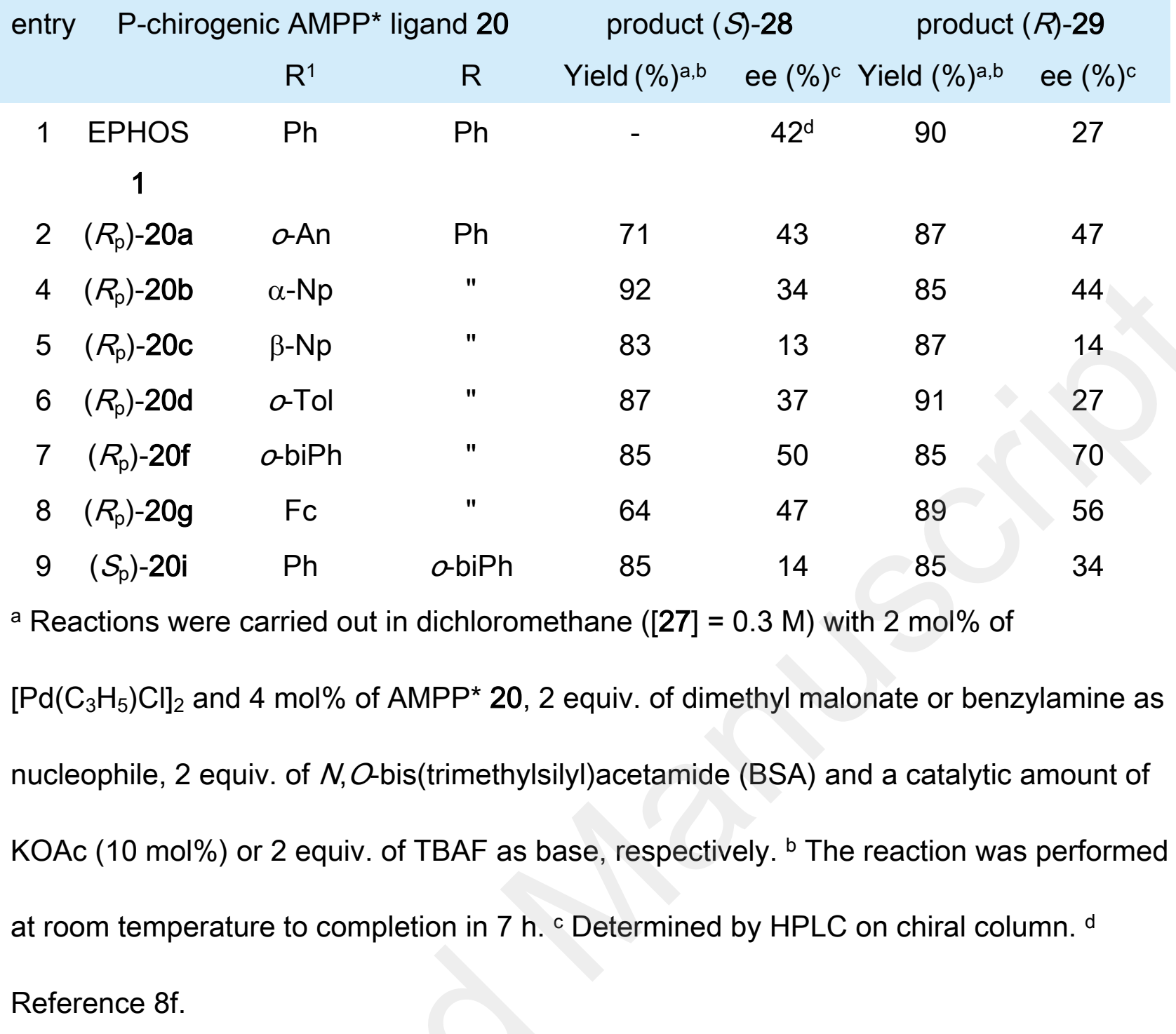

The allylated products 28 and 29 were obtained with moderate enantioselectivities up to $70 \%$ e.e. (Table 3). The P-chirogenic phosphinite substituents of the AMPP* ligands 20 in this catalyzed allylic reaction, did not show significant effect on the stereoselectivity. The products $(S)-28$ and $(R)-29$ were obtained with low to moderate enantioselectivities of 13$56 \%$ e.e., compared to $27-42 \%$ for the EPHOS 1 (Table 3, entries 1-6 and 8 ). This was after changing the $\mathrm{R}^{1}$ substituents of $\mathrm{AMPP}^{*} 20$ by -anisyl, $\alpha$-naphtyl, $\beta$-naphtyl, 0 -tolyl or 
ferrocenyl. However, when $\mathrm{R}^{1}=$ o-biphenyl, the enantioselectivities obtained for the products (S)-28 and (R)-29 reached 50 and $70 \%$ e.e., respectively (entry 7 ). When $\mathrm{R}$ is an o-biphenyl, lower enantioselectivities up to $34 \%$ e.e. were obtained using the ligand $\left(S_{p}\right)$ 20i compared to epimer $\left(R_{\mathrm{p}}\right)$-20f (entry 9 vs entry 7$)$. Results in Tables 2 and 3 show that the enantioselectivities in the palladium catalyzed asymmetric allylic reactions was considerably increased with the AMPP* 13 bearing a P-chirogenic aminophosphine moiety, even if the best asymmetric induction was obtained with the o-biphenyl-containing AMPP* ligand $20 f$.

From a mechanistic standpoint, the P-chirogenic AMPP* ligands 13 and 20 were useful to improve the understanding of the enantioselectivity $(R$ or $S$ ) in the asymmetric catalyzed allylations by comparing the structural modifications of the ligands at the aminophosphine or phosphinite-arms. X-ray structures of the AMPP* $\cdot \mathrm{PdCl}_{2}$ complexes 30,31 and 32 , prepared by ligand exchange of the dichlorobis(acetonitrile)palladium with the P-chirogenic $\operatorname{AMPP}^{*}\left(R_{\mathrm{p}}\right)-13 \mathrm{f},\left(R_{\mathrm{p}}\right)-13 \mathrm{~g}$ and $\left(R_{\mathrm{p}}\right)-20 \mathrm{~b}$, respectively, are shown Figure 1 and in SI. 
(a)

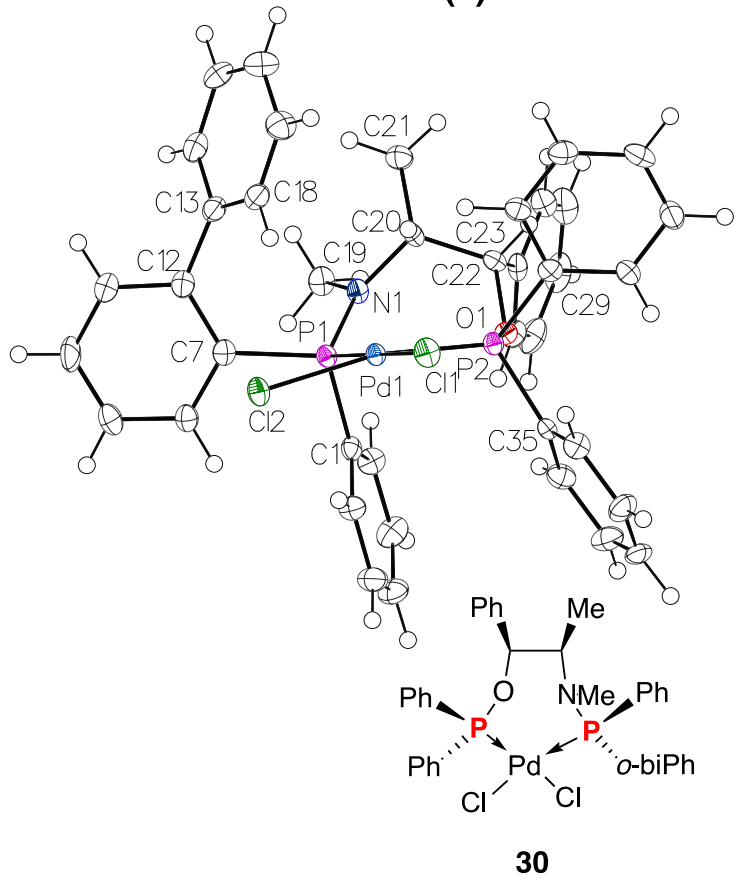

(b)

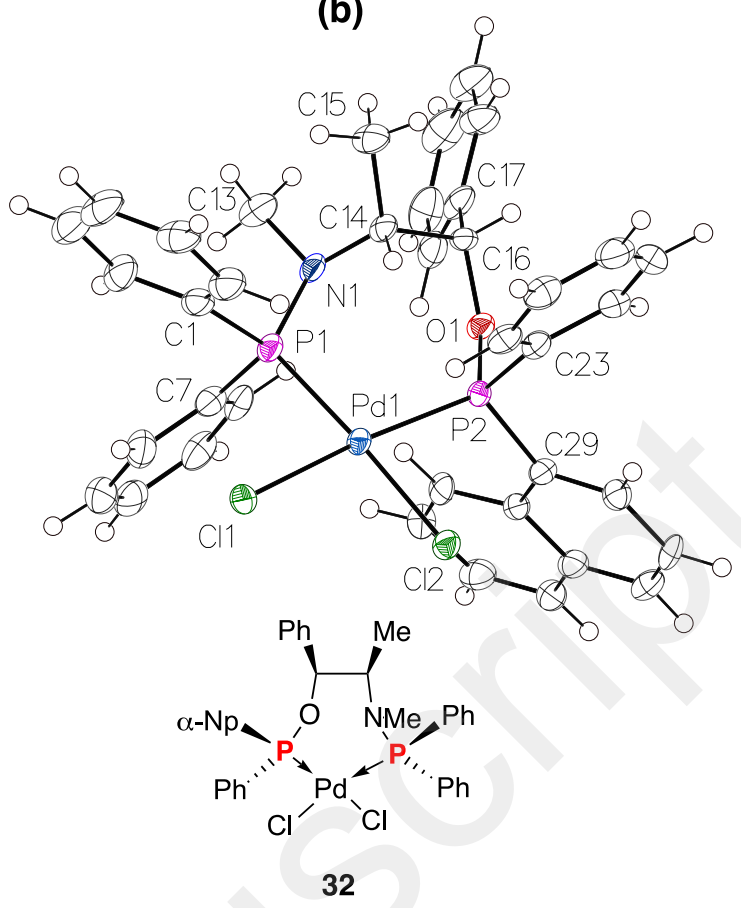

Figure 1. ORTEP view of palladium complexes $\left[\mathrm{Pd}(13 f) \mathrm{Cl}_{2}\right] 30$ and $\left[\mathrm{Pd}(20 \mathrm{~b}) \mathrm{Cl}_{2}\right] 32$ showing thermal ellipsoids at $50 \%$ probability level. Selected mean bond lengths ( $\AA$ ), angles $\left({ }^{\circ}\right.$ ) and dihedral angles $\left({ }^{\circ}\right)$. Complex 30: Pd1-P1 $=2.2579(12) ; \mathrm{Pd} 1-\mathrm{P} 2=$ 2.2330(12); Pd1-Cl1 2.3329(12); Pd1-Cl2 = 2.3591(12); P2-Pd1-P1 = 93.34(4); Pd1-P1$\mathrm{C} 7-\mathrm{C} 12=-98.4(4) ; \mathrm{O} 1-\mathrm{P} 2-\mathrm{P} 1-\mathrm{N} 1=-36.28(19) ; \mathrm{C} 7-\mathrm{C} 12-\mathrm{C} 13-\mathrm{C} 18=-51.5(7) ; \mathrm{P} 1-\mathrm{C} 7-\mathrm{C} 12-$ $\mathrm{C} 13=-6.5(7)$. Complex 32: $\mathrm{Pd} 1-\mathrm{P} 1=2.2582(17) ; \mathrm{Pd} 1-\mathrm{P} 2=2.2430(15) ; \mathrm{Pd} 1-\mathrm{Cl} 1$ 2.3404(15); $\mathrm{Pd} 1-\mathrm{Cl} 2$ = 2.3570(16); P2-Pd1-P1 = 100.16(6); O1-P2-P1-N1 = -18.1539(9); Pd1-P2-C29-C38 = 69.2 (6); P2-C29-C38-C37 = -3.126(1).

The seven-membered ring in $\mathrm{PdCl}_{2}$-complexes 30-32 adopted a boat-like geometry, with a slight distorsion $\mathrm{O} 1-\mathrm{P} 2-\mathrm{P} 1-\mathrm{N} 1$ of $-36^{\circ}$ and $-18^{\circ}$, respectively. This was explained by the 
required equatorial positions of the methyl and phenyl substituents of the ephedrine chain (here, cis-positioning). A shorter phosphinite-Pd bond was also noted with the Pd1-P2 and

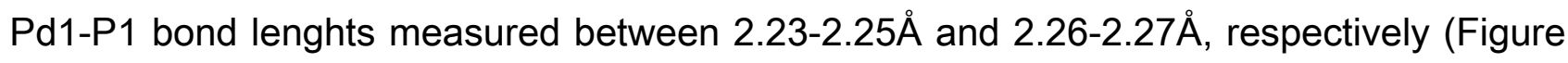
1 and $\mathrm{SI}$ ). Very similar structures have already been observed in case of rhodium or ruthenium complexes with AMPP derived from ephedrine ${ }^{9 b, c, 24 H e r e, ~ t h e ~ s t r u c t u r e ~ o f ~ t h e ~}$ $\mathrm{PdCl}_{2}$-complex 30 prepared with the ligand $\left(R_{\mathrm{p}}\right)-13 \mathrm{f}$ interestingly showed the 0 -biphenyl substituent of the aminophosphine moiety placed perpendicular to the palladium square (i.e. $\mathrm{P} 1 \mathrm{P} 2 \mathrm{PdCl}_{2}$ ) with a dihedral angle Pd1-P1-C7-C8 of $103.5(4)^{\circ}$ (Figure 1a). In addition, the biphenyl group adopted a staggered conformation with a dihedral angle $\mathrm{C} 7-\mathrm{C} 12-\mathrm{C} 13-$ C14 of $-46.1(5)^{\circ}$. This could explain the strong influence of the ligand $\left(R_{\mathrm{p}}\right)-13 \mathrm{f}$ in the palladium sphere of coordination and consequently the high enantioselectivities observed in allylic reactions (Figure 1a; Table 2, entry 5: e.e. up to $82 \%$ ), By contrast, the $\alpha$-naphtyl substituent in the $\mathrm{PdCl}_{2}$-complex 32, located in back area of the $\mathrm{Pd}$-sphere of coordination, might explain the moderate asymmetric induction resulting from ligand $\left(R_{\mathrm{p}}\right)-20 \mathrm{~b}$ (Figure $1 \mathrm{~b}$; Table 3, entry 2: e.e. up to $44 \%$ ).

The origin of the observed enantioselectivity (i.e. $R$ or $S$ ) has been addressed by DFT computations, notably for the $\pi$-allylpalladium complexes $33-35$ derived from the AMPP* ligands $\left(R_{\mathrm{p}}\right)-13 \mathrm{f},\left(S_{\mathrm{p}}\right)-13 \mathrm{i}$ and $\left(R_{\mathrm{p}}\right)-20 \mathrm{f}$, respectively (Schemes 5, 6; Table 4 and $\left.\mathrm{SI}\right)$. These 
ligands were derived from (+)-ephedrine and bearing a P-chirogenic o-biphenylaminophosphine or -phosphinite moiety, led to catalyzed allylations with enantioselectivities up to $91 \%(R)$ or $95 \%(S)$ (Table 2, entries 5, 8; Table 3, entry 7 ). $\pi$-Allylpalladium complexes 33-35 geometry was optimized considering the boat conformation of the seven-membered ring observed in the $\mathrm{X}$-ray structure of $\mathrm{PdCl}_{2}$ complexes 30-32. This included changing the two chlorides by the $\pi$-allyl ligand (PhCCCPh). Both preferred $\mathrm{M}$ - or $\mathrm{W}$ - orientations of the $\pi$-allyl moiety coordinated onto the palladium (II), were investigated (see Figures S22-S76, SI). The half-chair conformation in complexes 33-35 were also examined because the biphenyl substituent at the axial position to the $\mathrm{Pd}$-square plane in complexes 34 and 35 , could induce steric hindrance $\left(\mathrm{R}^{\mathrm{a}}\right.$ or $\mathrm{R}^{\mathrm{c}}=$ o-biPh, Scheme 5 ). In total four starting conformations were optimized for the $\pi$-allyl complexes $33-35$, named $33-35 \mathrm{M}$ - or $33-35 \mathrm{~W}$ (boat or half-chair). A maximal energy differences between all these species of $16.1 \mathrm{KJmol}^{-1}$ was observed (Scheme 5, Table S61, SI).

Scheme 5 . Geometry Optimization of the $\pi$-Allylpalladium-AMPP* Complexes 33-35 


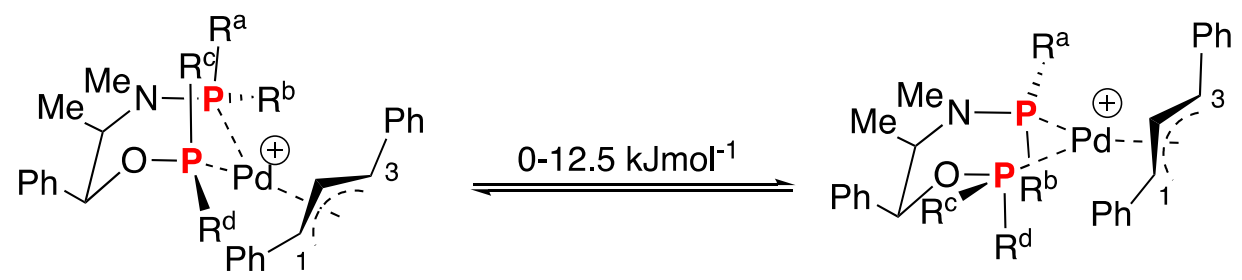

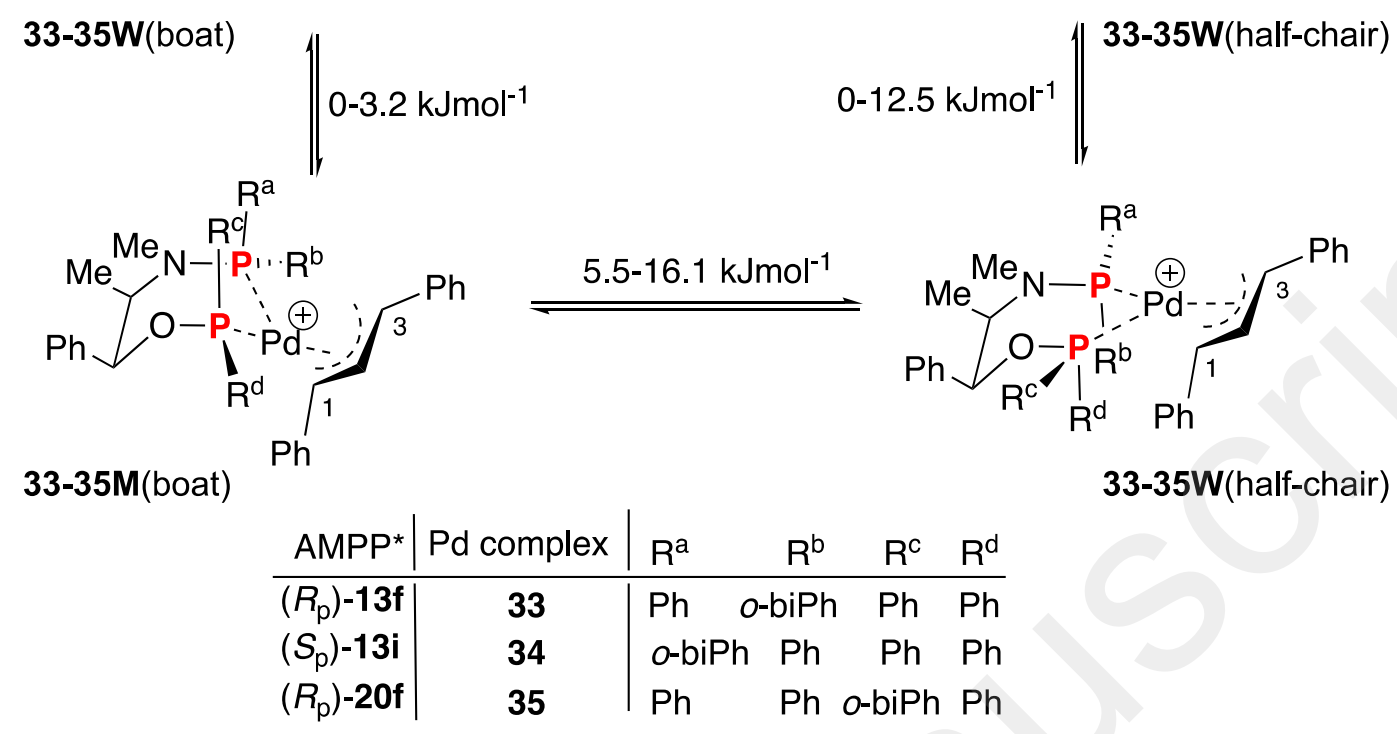

The optimized structures of complexes 33-35 in the ground state, selected bond lenghts, energies, electronic affinities (Fukui function), representation of HOMO/LUMOs and their contributions at $\mathrm{C} 1$ and $\mathrm{C} 3$ positions of the $\pi$-allyl group, are detailled in SI. As the Pdcomplexes 34-35 adopted chair or half-chair conformations more or less twisted, for clarity purposes they were denoted as 34-35 (boat or half-chair). A selection of key data from Tables S61, S65 to S76, is reported in Table 4. Among all these optimized structures, the $\pi$-allyl Pd-complexes 33W(boat), 33M(boat), 34M(boat), 34W(boat), 34W(half-chair), $35 \mathrm{M}$ (boat), 35W(half-chair) and $35 \mathrm{~W}$ (boat) exhibited the lowest calculated total energies with differences not exceeding $3.2 \mathrm{KJmol}^{-1}$ (Tables 4 and $\mathrm{SI}$ ). The observed enantioselectivity provided from the nucleophilic attack on either the C1 or C3 of the $\pi$-allyl 
complexed moiety. The Pd-C3 bond, trans to the phosphinite moiety in the Pd-square planar center was most commonly longer than the $\mathrm{Pd}-\mathrm{C} 1$ bonds and was observed in similar X-ray structures of the ProNOP ligand $2 .{ }^{25}$ However, computations showed that the Pd-C1 and Pd-C3 bond lenghts also depend on the Pd-complex conformation (Table 4). Even if the electroaffinity values of the $\mathrm{C} 1$ and $\mathrm{C} 3$ atoms in all $\pi$-allyl complexes $33-35$ are of unequal value, the enantioselectivity of the allylation is much better explained by molecular orbital (MO) than electrostatic interactions between the nucleophile and the $\pi$ allyl moiety (Table 4; see detail Table S61 to S76, SI). ${ }^{26}$

\section{Table 4. Data Selection of the Optimized Structures of Complexes 33-35 (DFT).}

\begin{tabular}{|c|c|c|c|c|c|c|c|}
\hline \multirow[t]{2}{*}{ entr } & \multirow[t]{2}{*}{ complex } & \multicolumn{2}{|c|}{ Relative total energy } & \multicolumn{2}{|c|}{ Selected bond length } & \multicolumn{2}{|c|}{ LUMO rel. atomic cont. } \\
\hline & & & $\Delta\left(\mathrm{KJ} \mathrm{mol}^{-}\right.$ & $\mathrm{Pd}-\mathrm{C} 3$ & $\mathrm{Pd}-\mathrm{C} 1$ & C3 (\%) & C1 (\%) \\
\hline 1 & $33 \mathrm{M}$ (boat) & -65202.8789 & 2.5 & 2.36703 & 2.27063 & 13.79 & 10.71 \\
\hline 2 & $33 W$ (boat) & -65202.9047 & 0 & 2.33082 & 2.28902 & 12.25 & 11.90 \\
\hline 3 & $34 \mathrm{M}$ (boat) & -65202.6722 & 2.0 & 2.24787 & 2.35432 & 9.06 & 16.52 \\
\hline 4 & $34 W$ (boat) & -65202.6928 & 0 & 2.35003 & 2.26769 & 12.73 & 11.89 \\
\hline 5 & 34W(half- & -65202.6928 & 0 & 2.34958 & 2.26783 & 15.93 & 9.81 \\
\hline 6 & $\begin{array}{c}\text { rhair) } \\
\text { 35M(boat) }\end{array}$ & -65202.7893 & 3.2 & 2.27871 & 2.37415 & 10.94 & 13.84 \\
\hline 7 & $35 \mathrm{~W}$ (boat) & -65202.8227 & 0 & 2.27178 & 2.32581 & 10.63 & 13.71 \\
\hline 8 & $\begin{array}{c}35 \mathrm{~W} \text { (half- } \\
\text { rhair) }\end{array}$ & -65202.8227 & 0 & 2.27193 & 2.32565 & 10.64 & 13.71 \\
\hline
\end{tabular}


The most stable Pd-complexes 33M and 33W, derived from AMPP* ligand $\left(R_{\mathrm{p}}\right)-13 \mathrm{f}$, were in boat conformation and in equilibrium from each other with an energy difference of 2.5 $\mathrm{KJmol}^{-1}$. This was due to the changing $\mathrm{M}$ - or $\mathrm{W}$-shape of the $\pi$-allyl group (Scheme 6a; Table 4, entries 1 and 2). In this case, the enantioselectivity was explained by a favored nucleophilic attack at the $\mathrm{C} 3$ position of the complex $33 \mathrm{M}$ (boat), leading to the products (S)-28 or (R)-29 respectively after reaction with malonate or benzyl amine (Scheme 6a). This selectivity was possible by a longer $\mathrm{Pd}-\mathrm{C} 3$ bond length and a larger LUMO relative atomic contribution at the $\mathrm{C} 3$ position of the $\pi$-allyl group, higher in $33 \mathrm{M}$ (boat) than $33 W$ (boat). This allows the favored interaction with the nucleophile and consequently the cleavage of the Pd-C3 bond to enantioselectively afford the corresponding allylated product (Table 4, entries 1 and 2).

Scheme 6. Computed Stereochemical Course of Pd-Catalyzed Allylations using AMPP* Ligands $\left(R_{\mathrm{p}}\right)-13 \mathrm{f},\left(S_{\mathrm{p}}\right)-13 \mathrm{i}$ or $\left(R_{\mathrm{p}}\right)-20 \mathrm{f}$. 


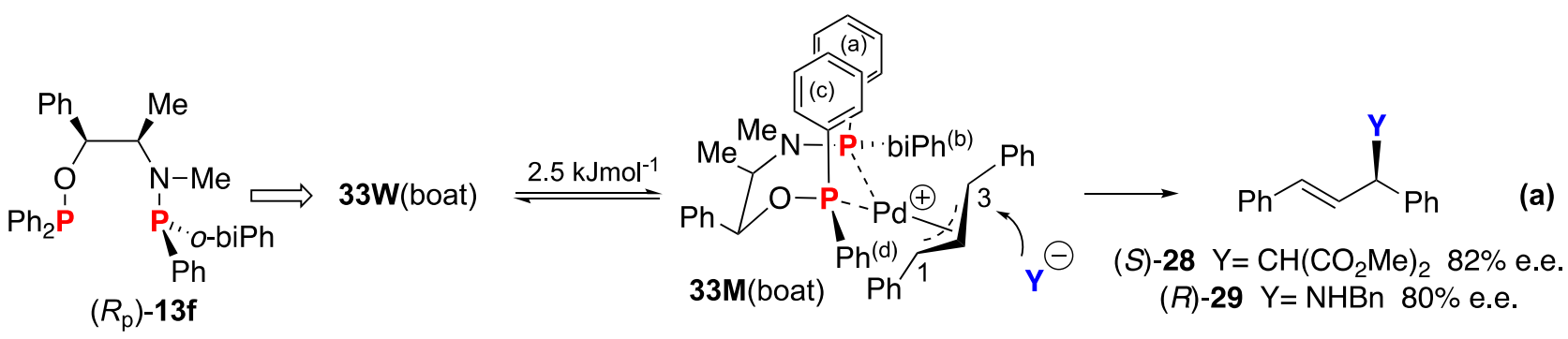

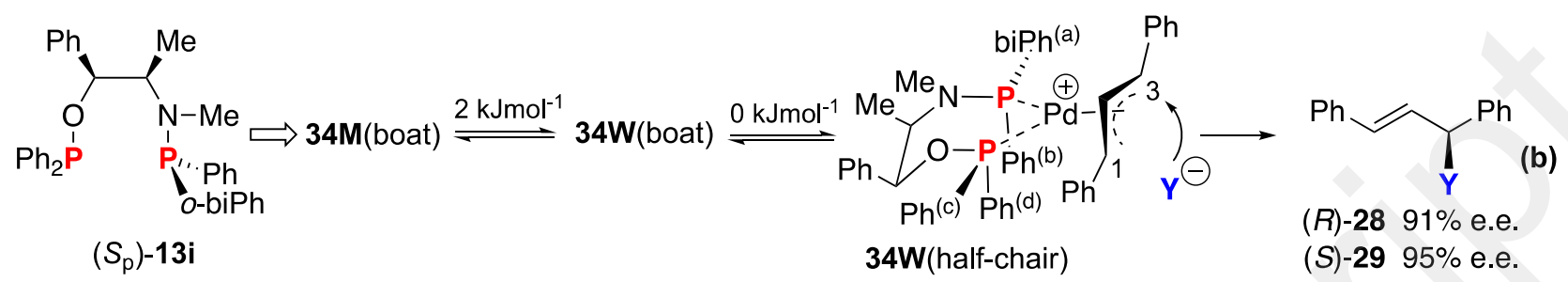

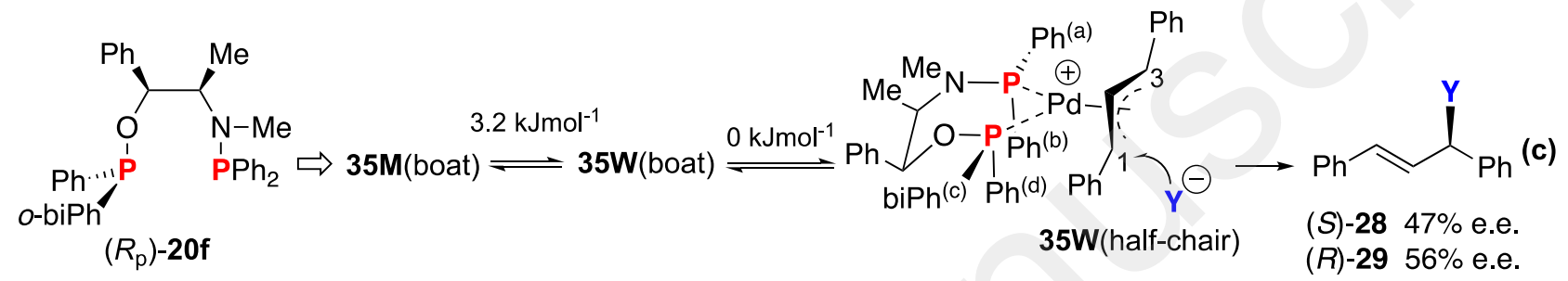

In contrast, the computed structures for the Pd-complex derived of the AMPP* ligand $\left(S_{p}\right)$ 13i indicated three species $34 \mathrm{M}$ (boat), $34 \mathrm{~W}$ (boat) and $34 \mathrm{~W}$ (half-chair) with lower energy

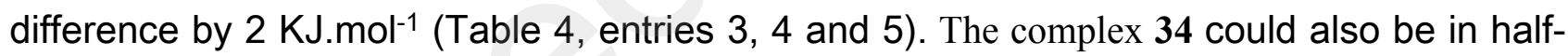
chair conformation (i.e. $34 \mathrm{~W}$ (half-chair)), due to steric hindrance of the biphenyl substituent when it is in axial position with regard to the Pd-square as in boat form (Scheme $5, \mathrm{R}^{\mathrm{a}}=$ biPh, $\left.\mathrm{R}^{\mathrm{b}, \mathrm{c}, \mathrm{d}}=\mathrm{Ph}\right)$. The observed enantioselectivities of the products $(R)-28$ and $(S)-29$ were again explained by a favored nucleophilic attack at the $\mathrm{C} 3$ position of the complexes $34 \mathrm{~W}$ (half-chair) or $34 \mathrm{~W}$ (boat). This was due to their longer Pd-C3 bonds and higher LUMO contributions at their C3 positions i.e $2.35 \AA, 15.93 \%$ and $12.73 \%$, respectively (Scheme 
6b, Table 4, entries 4 and 5). However, the computed Pd-C1 bond length and the LUMO contribution for the complex $34 \mathrm{M}$ (boat) were higher at the $\mathrm{C} 1$ than $\mathrm{C} 3$ position of the $\pi$-allyl group, i.e. $2.35 \AA$ and $16.52 \%$ vs $2.25 \AA$ and $9.06 \%$ (Table 4 , entry 3 ). In this case the enantioselectivity was explained by a nucleophilic attack at the C1-position of the $\pi$-allyl group. It is noteworthy that all stereochemical course from the three lower stable $\pi$-allyl Pdcomplexes 34 resulted in the same enantioselectivities, justifying the obtained high enantiomeric excesses up to $95 \%$ using the ligand $\left(S_{p}\right)-13 i$ (Scheme $6 b$ ).

Finally, the more stable optimized complexes 35 derived from AMPP* ligand $\left(R_{\mathrm{p}}\right)-20 \mathrm{f}$ were either in boat or in half-chair conformation and with a $\pi$-allyl group in both $\mathrm{M}$ - or $\mathrm{W}$ shape (Scheme 6c; Table 4, entries 6, 7 and 8). All these species were in equilibrium from each other with an energy difference of $3.2 \mathrm{KJ} \mathrm{mol}^{-1}$. The modest enantioselectivity was explained by a nucleophilic attack at the $\mathrm{C} 1$ position of the complexes $35 \mathrm{~W}$ (boat) or $35 \mathrm{~W}$ (half-chair), but also in a lesser extent of 35M (boat) which led to reverse enantiomers $(R)-28$ or $(S)-29$. This was due in all case to their longer $\mathrm{Pd}-\mathrm{C} 1$ than $\mathrm{Pd}-\mathrm{C} 3$ bonds and their higher LUMO contributions at the $\mathrm{C} 1$ rather than $\mathrm{C} 3$ position, i.e. $2.37 \AA$ and $13.84 \%, 2.33$ $\AA$ and $13.71 \%$ vs $2.27 \AA$ and $10.63 \%$, respectively (Scheme 6b, Table 4, entries 6,7 and 8). 


\section{CONCLUSION}

We have developed an important series of chiral aminophosphine-phosphinite ligands bearing a chirality at the phosphorus atom of the aminophosphine or phosphinite moiety $\left(\mathrm{AMPP}^{*}\right)$. Until now the design of $\mathrm{AMPP}^{*}$ with a P-chirogenic phosphinite center has been poorly investigated. We synthetized this series with the ephedrine methodology used in stereoselective synthesis of P-chirogenic phosphines. The synthesis of AMPP* ligands with P-chirogenic aminophosphine moieties is based on the stereospecific ring opening of an oxazaphospholidine-borane by reaction with organolithium reagents, trapping the aminophosphine-borane intermediates with a chlorophosphine and borane decomplexation. A broader design of $\mathrm{AMPP}^{*}$ ligands notably on phosphinite center was achieved thank to an unprecedented stereospecific $\mathrm{N} \rightarrow \mathrm{O}$ phosphinyl migration process recently developed in our group. When the aminophosphine-boranes were heated at $50^{\circ} \mathrm{C}$ in the presence of $\mathrm{DABCO}, \mathrm{P}$-chirogenic phosphinites were obtained by $\mathrm{N} \rightarrow \mathrm{O}$ phosphinyl migration. Their reaction with chlorophosphines led then to the corresponding free AMPP* with P-chirogenic phosphinite moiety. Synthesis efficiency was demonstrated by the stereoselective synthesis of the four epimers of the o-biphenyl containing AMPP* ligands, with $(S)$ - or $(R)$ - absolute configuration at the P-centers. Twenty nine AMPP* including eight with a P-chirogenic phosphinite moiety were investigated in palladium-catalyzed 
asymmetric allylic reactions. The enantioselectivities varied from $91 \%(R)$ to $95 \%$ e.e. (S), according to the spatial position of the P-substituents in the palladium sphere of coordination. The best asymmetric inductions were obtained with AMPP* bearing Pchirogenic aminophosphine moieties. The $(S)$ - or $(R)$-enantioselectivity depends on the absolute configuration at the phosphorus atom. X-ray crystallographic data for relevant $\mathrm{Pd}$ AMPP* $^{*}$ complexes and computer modeling explained enantioselectivities origin, based on MO interactions of the most stable conformers with nucleophiles. The selectivity provided from the nucleophilic attack at the $\mathrm{C} 3$ or $\mathrm{C} 1$ position of the complexed $\pi$-allyl group. It was favorized by the interaction of the nucleophile with the LUMO having the larger contribution in one of those positions, and also by the cleavage of the corresponding longer $\mathrm{Pd}-\mathrm{C} 3$ or Pd-C1 bond.

To conclude, this methodology to prepare P-chirogenic modified EPHOS ligands derived from ephedrine, opens up further possibilities for optimizing and predict enantioselectivities in asymmetric catalyzed processes by designing AMPP* derived from aminoalcohols.

\section{EXPERIMENTAL SECTION}

4.1. General Information. All reactions were carried out using standard Schlenk techniques under an inert atmosphere, unless stated otherwise. Dichloromethane, toluene, 
pentane, THF and diethylether were dried using a MBRAUN SPS 800. Chromatographic grade hexane and isopropanol for HPLC were used without further purification. Commercially available methyllithium, $s$-butyllithium, $t$-butyllithium, chlorodiphenylphosphine, phosphorus trichloride, N-methylmorpholine, 1bromonaphtalene, 2-bromonaphtalene, 2-bromobiphenyl and bromocyclohexane were used without purification, whereas 2-bromoanisole was distillated before use. EPHOS 1 and AMPP* 13a-c, 13f-h, 13j-l, 13u and their corresponding diborane complexes 12 were synthesized according to literature procedures. ${ }^{9 a, b, 10 a}$ The 2-benzyloxy-27a and 2isopropoxybromobenzene ${ }^{27 b}$ were prepared from 2-bromophenol according to reported procedures. The 4-bromo-2,6-bis( $t$-butyl)anisole was synthesized from 4-bromo-2,6-bis $(t-$ butyl)phenol, according to a modified procedure using $\mathrm{K}_{2} \mathrm{CO}_{3}$ as base. ${ }^{27 c}$ The bromo-2,6dimethoxybiphenyl has been prepared and generously provided by Dr F. Leroux (LIMAStrasbourg). ${ }^{28}$ Thin layer chromatography was performed on silica chromagel $\left(60 \mu \mathrm{m} \mathrm{F}_{254}\right)$ and exposed by UV, potassium permanganate or iodine treatment. Flash chromatography was carried out with the indicated solvents using silica gel 60 (60AAC, 35-70 $\mu \mathrm{m})$. HPLC analyses were performed on a chromatograph equipped with a UV detector at $\lambda=210$ and $254 \mathrm{~nm}$. The ${ }^{1} \mathrm{H},{ }^{13} \mathrm{C}\left\{{ }^{1} \mathrm{H}\right\}$ and ${ }^{31} \mathrm{P}\left\{{ }^{1} \mathrm{H}\right\}$ NMR spectra were recorded on $600,500,400$ or 300 $\mathrm{MHz}$ spectrometers at ambient temperature, using tetramethylsilane (TMS) as internal 
reference for ${ }^{1} \mathrm{H}$ and ${ }^{13} \mathrm{C}$ spectra, and phosphoric acid (85\%) as external reference for ${ }^{31} \mathrm{P}$ NMR. Data were reported as $\mathrm{s}=$ singlet, $\mathrm{d}=$ doublet, $\mathrm{t}=$ triplet, $\mathrm{q}=$ quartet, $\mathrm{m}=$ multiplet, br.s = broad signal, coupling constant(s) in Hertz. Infrared spectra were recorded on FT-IR instrument and the data are given in $\mathrm{cm}^{-1}$. Melting points were measured on a Kofler melting points apparatus. Optical rotation values were determined at $20{ }^{\circ} \mathrm{C}$ on a polarimeter at $589 \mathrm{~nm}$ (sodium lamp). The mass spectra and accurate mass measurements (HRMS) were performed under (ESI) conditions with a micro Q-TOF detector or Orbitrap detector, or in the MALDI/TOF reflectron mode using dithranol as a matrix. Elemental analyses were performed with a precision superior to $0.3 \%$ on a CHNSO instrument apparatus.

Crystal Structure Determination. All experimental data procedure and refinement are detailed in the part B of the Supplementary Information (SI) for each compound. Data CCDC-1982667, 1982668, 1982669, 1982665, 1982666, 1982663, 1982664, 1982661, 1982662, 1982659, 1982660, 1982656, 1982657, 1982658, 1982652, 1982653, 1982654, 1982650 and 1982651 for compounds $\left.\left(R_{\mathrm{p}}\right)-11 \mathrm{e},\left(R_{\mathrm{p}}\right)-11 \mathrm{~h},\left(M, S_{\mathrm{p}}\right)-11 \mathrm{v}, R_{\mathrm{p}}\right)-12 \mathrm{f},\left(R_{\mathrm{p}}\right)-12 \mathrm{~g}$, $\left(S_{\mathrm{p}}\right)-12 \mathrm{i},\left(S_{\mathrm{p}}\right)-15 \mathrm{e},\left(S_{\mathrm{p}}\right)-21 \mathrm{a},\left(S_{\mathrm{p}}\right)-21 \mathrm{~b},\left(R_{\mathrm{p}}\right)-21 \mathrm{c},\left(R_{\mathrm{p}}\right)-21 \mathrm{~d},\left(S_{\mathrm{p}}\right)-21 \mathrm{~d},\left(R_{\mathrm{p}}\right)-21 \mathrm{e},\left(R_{\mathrm{p}}\right)-21 \mathrm{f},\left(R_{\mathrm{p}}\right)-$ $21 \mathrm{~g},\left(S_{\mathrm{p}}\right)-21 \mathrm{~h}, 30,31$ and 32 , respectively contain the supplementary crystallographic data 
for this paper. These data can be obtained free of charge from The Cambridge Crystallographic Data Centre via www.ccdc.cam.ac.uk/data_request/cif

Computational Details All density functional theory (DFT) calculations were performed with Gaussian 16 and were detailed in the Supplementary Information (part C, SI). The DFT ground state calculations were carried out using the B3LYP/genecp method. A 6-31g (d, p) basis set was used for C, H, N and O atoms. VDZ (valence double $\zeta$ ) with SBKJC effective core potentials was used for P and Pd atoms.

\subsection{Synthesis of the oxazaphospholidine-2-borane complexes 10.}

4.2.1. (2S,4R,5S)-3,4-Dimethyl-2,5-diphenyl-1,3,2-oxazaphospholidine-2-borane (-)- and $(+)$-10a. These starting compounds were prepared from bis(dimethylamino)phenylphosphine and (+)- and (-)-ephedrine 9, respectively, according to a methodology already described.9.15

\subsection{2. (2S,4R,5S)-3,4-Dimethyl-2-biphenyl-5-phenyl-1,3,2-oxazaphospholidine-2-borane}

(-)-10b. This compound was prepared from 2-chloro-1,3,2-oxazaphospholidine according to a modified procedure using o-biphenyllithium as reagent. ${ }^{14,15}$ To a solution of 2-chloro1,3,2-oxazaphospholidine $(1 \mathrm{mmol})$ previously prepared by reaction of $\mathrm{PCl}_{3}$ with the $(+)$ ephedrine 9 and $\mathrm{N}$-methylmorpholine, was added at $-78{ }^{\circ} \mathrm{C}$ a solution of $\mathrm{o}$-biphenyllithium in diethyl ether $(0.7 \mathrm{mmol})$. After stirring overnight, borane-dimethylsulfide $(1.1 \mathrm{mmol})$ was added and the mixture was stirred under argon for $6 \mathrm{~h}$. After hydrolysis, the organic phase 
was successively extracted with ethyl acetate, dried over $\mathrm{MgSO}_{4}$ and filtered. The solvent was removed under vacuum and the residue was purified by chromatography on silica gel using a mixture of petroleum ether/dichloromethane (1:1) as eluent. The oxazaphospholidine-borane complex (-)-10b was recrystallized from a mixture of methanol/dichloromethane. $0.16 \mathrm{~g}, 43 \%$ yield; White crystals; $M p=155{ }^{\circ} \mathrm{C} ; \mathrm{R}_{\mathrm{f}}=0.53$ (petroleum ether/dichloromethane 1/1); $[\alpha]_{\mathrm{D}}^{20}=-12.8$ (c $\left.0.3, \mathrm{CHCl}_{3}\right) .{ }^{1} \mathrm{H} \mathrm{NMR}(300 \mathrm{MHz}$, $\left.\mathrm{CD}_{2} \mathrm{Cl}_{2}\right): \delta-0.18-1.24(\mathrm{~m}, 3 \mathrm{H}), 0.50(\mathrm{~d}, J=6.5 \mathrm{~Hz}, 3 \mathrm{H}), 2.32(\mathrm{~d}, J=10.2 \mathrm{~Hz}, 3 \mathrm{H}), 3.21-3.33$ (m, 1H), $4.56(\mathrm{dd}, J=6.0,2.3 \mathrm{~Hz}, 1 \mathrm{H}), 7.02-7.06(\mathrm{~m}, 2 \mathrm{H}), 7.14-7.22(\mathrm{~m}, 4 \mathrm{H}), 7.26$ (br.s, 5H), 7.30-7.43 (m, 2H), 7.77 (ddd, $J=11.8,7.4,1.2 \mathrm{~Hz}, 1 \mathrm{H}) .{ }^{31} \mathrm{P}\left\{{ }^{1} \mathrm{H}\right\} \mathrm{NMR}(121.5 \mathrm{MHz}$, $\mathrm{CD}_{2} \mathrm{Cl}_{2}$ ): $\delta 132.5$ (br.s). Anal. calcd for $\mathrm{C}_{22} \mathrm{H}_{25} \mathrm{BNOP}$ : C 73.15, H 6.98, N 3.88; found C 73.02, H 7.03, N 3.98.

\subsection{Synthesis of aminophosphine-boranes 11.}

4.3.1. Preparation of aryllithium reagents by metal/halide exchange. To a solution of bromoaryl derivatives (2 M) in THF was added 1 equivalent of $s$-butyllithium at $0{ }^{\circ} \mathrm{C}$ or 2 equivalents of $t$-butyllithium at $-78^{\circ} \mathrm{C}$. After the formation of a white precipitate, the mixture was stirred at $0{ }^{\circ} \mathrm{C}$ for $1 \mathrm{~h}$ (or at $-78^{\circ} \mathrm{C}$ in the second case). The organolithium reagent was dissolved with a minimum of dry THF before use. 
4.3.2. Preparation of ferrocenyllithium reagent by ferrocene deprotonation. A $50 \mathrm{~mL}$

three-necked flask equipped with a magnetic stirrer under an argon atmosphere was charged with ferrocene $(0.74 \mathrm{~g}, 4 \mathrm{mmol})$ and THF $(10 \mathrm{~mL})$. At $0{ }^{\circ} \mathrm{C}, t$-BuLi $(2.75 \mathrm{~mL}, 1.6 \mathrm{M}$ in hexane, $4.4 \mathrm{mmol}$ ) was added dropwise, and the reaction mixture was stirred at $0{ }^{\circ} \mathrm{C}$ for $1 \mathrm{~h}$, before use.

4.3.3. Synthesis of aminophosphine-boranes 11: General procedure. In a $50 \mathrm{~mL}$ threenecked flask, equipped with a magnetic stirrer and an argon inlet, $5 \mathrm{mmol}$ of the oxazaphospholidine borane complex 10 were dissolved in $5 \mathrm{~mL}$ of anhydrous THF. The mixture was cooled at $-78{ }^{\circ} \mathrm{C}$ and 2 equiv. $(10 \mathrm{mmol}$ ) of the organolithium reagent were slowly added. The resulting mixture was stirred and warmed to RT until the starting material was completely consumed, and hydrolyzed at $0{ }^{\circ} \mathrm{C}$ with $2 \mathrm{~mL}$ of water. The THF was removed under reduced pressure and the aqueous layer was extracted several times with dichloromethane. The combined organic phases were dried over $\mathrm{MgSO}_{4}$ and the solvent was removed. The residue was purified by chromatography on a column of silica gel, using a mixture of toluene/AcOEt as eluent, to afford aminophosphine-boranes 11 . The aminophosphine-boranes 11 were typically recrystallized using a mixture of hexane/isopropanol (7:3). 
4.3.4. The o-anisyl-,, ${ }^{11 \mathrm{~b}} \alpha$-naphtyl-,, ${ }^{11 \mathrm{~b}, 29} \beta$-naphtyl-, ${ }^{11 \mathrm{~b}, 29 \mathrm{~b}}$ o-tolyl-, ${ }^{30,31}$ p-tolyl-,, ${ }^{31}$ o-biphenyl-

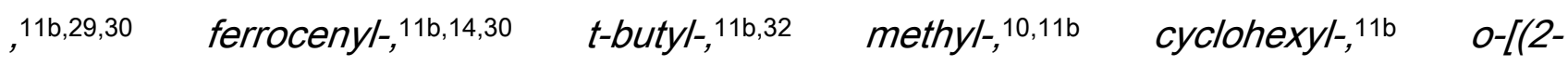
methoxyethoxy)methoxy]phenyl-, ${ }^{9 b}$ o-isopropoxyphenyl-, ${ }^{31}$ 3,5-xylyl-, ${ }^{15}$ 3,5-di-t-butylphenyl,33 2-(2',6'-dimethoxy)biphenyl-, ${ }^{34}$ calix[4]arenyl-,9c aminophosphines $11 \mathrm{a}-\mathrm{h}, 11 \mathrm{j}-\mathrm{m}, 110$, 11p, 11u, respectively, were prepared from the appropriate oxazaphospholidine-borane complex (+)- or (-)-10a or (-)-10b, according to the described procedure. These compounds exhibited satisfactory analytical and spectrochemical data in agreement with the literature.

4.3.5. ( $\left.R_{p}\right)-(-)-N-[(1 R, 2 S)-2-H y d r o x y-1-m e t h y l-2-p h e n y l e t h y l], \quad N-m e t h y l a m i n o(p h e n y l-p-$ tolyl) phosphine-borane 11e. ${ }^{31}$ This compound was synthesized by reaction of oxazaphospholidine-borane complex (-)-10a with p-tolyllithium reagent. Colorless crystals (1.64 g, 87\% yield). X-ray quality crystals were grown by slow evaporation of hexane. The structure and the data were reported in the $\mathrm{SI} ; R_{\mathrm{f}}=0.25$ (toluene/ethyl acetate $\left.9: 1\right) ;[\alpha]_{\mathrm{D}}^{20}=$ -44.3 (c 0.5, $\left.\mathrm{CHCl}_{3}\right) .{ }^{1} \mathrm{H}$ NMR (300 MHz, $\left.\mathrm{CDCl}_{3}\right): \delta 0.20-2.00(\mathrm{~m}, 3 \mathrm{H}), 1.26(\mathrm{~d}, J=6.7 \mathrm{~Hz}$, 3H), 1.89 (br.s, 1H), $2.41(\mathrm{~s}, 3 \mathrm{H}), 2.49(\mathrm{~d}, J=7.8 \mathrm{~Hz}, 3 \mathrm{H}), 4.25-4.39(\mathrm{~m}, 1 \mathrm{H}), 4.83(\mathrm{~d}, J=$ $6.6 \mathrm{~Hz}, 1 \mathrm{H}), 7.14-7.20(\mathrm{~m}, 2 \mathrm{H}), 7.25-7.44(\mathrm{~m}, 8 \mathrm{H}), 7.47-7.53(\mathrm{~m}, 4 \mathrm{H}) .{ }^{13} \mathrm{C}\left\{{ }^{1} \mathrm{H}\right\}$ NMR $(75.5$ $\left.\mathrm{MHz}, \mathrm{CDCl}_{3}\right): \delta 13.5(\mathrm{~d}, J=1.2 \mathrm{~Hz}), 21.5,30.4(\mathrm{~d}, J=3.7 \mathrm{~Hz}), 58.1(\mathrm{~d}, J=10.1 \mathrm{~Hz}), 78.7$ (d, $J=6.1 \mathrm{~Hz}), 126.8,127.6(\mathrm{~d}, J=61.7 \mathrm{~Hz}), 127.9,128.3(\mathrm{~d}, J=10.7 \mathrm{~Hz}), 128.5,129.2$ 
(d, $J=10.2 \mathrm{~Hz}), 130.6$ (d, $J=2.3 \mathrm{~Hz}), 130.9$ (d, $J=68.3 \mathrm{~Hz}), 132.0$ (d, $J=10.5 \mathrm{~Hz}), 132.5$

$(\mathrm{d}, J=10.6 \mathrm{~Hz}), 141.5(\mathrm{~d}, J=2.3 \mathrm{~Hz}), 142.5 .{ }^{31} \mathrm{P}\left\{{ }^{1} \mathrm{H}\right\} \mathrm{NMR}\left(121.5 \mathrm{MHz}, \mathrm{CDCl}_{3}\right): \delta+69.8-$

70.2 (m). HRMS (ESI/Q-TOF) calcd for $\mathrm{C}_{23} \mathrm{H}_{29} \mathrm{BNOPNa}[\mathrm{M}+\mathrm{Na}]^{+}: 400.19720$; found:

400.19738. Anal. calcd for $\mathrm{C}_{23} \mathrm{H}_{29} \mathrm{BNOP}$ : C 73.22, H 7.75, N 3.71; found C 73.10, H 7.73,

N 3.62.

4.3.6. $\quad\left(S_{p}\right)-(+)-N-[(1 R, 2 S)-2-H y d r o x y-1-m e t h y l-2-p h e n y l e t h y l], \quad N$-methylamino(o-

biphenyl) phenylphosphine-borane 11i. This compound was synthesized by reaction of

oxazaphospholidine-borane complex (-)-10b with phenyllithium reagent. White solid (1.91

g, $87 \%$ yield $) ; \mathrm{Mp}=56-58^{\circ} \mathrm{C} ; R_{\mathrm{f}}=0.45\left(\mathrm{CH}_{2} \mathrm{Cl}_{2}\right) ;[\alpha]_{\mathrm{D}}{ }^{20}=+9.9\left(\mathrm{c} 0.6, \mathrm{CHCl}_{3}\right) .{ }^{1} \mathrm{H} \operatorname{NMR}(300$

$\left.\mathrm{MHz}, \mathrm{CD}_{2} \mathrm{Cl}_{2}\right): \delta 0.52-1.82(\mathrm{~m}, 3 \mathrm{H}), 0.85(\mathrm{~d}, J=6.9 \mathrm{~Hz}, 3 \mathrm{H}), 2.43(\mathrm{~d}, J=8.0 \mathrm{~Hz}, 3 \mathrm{H}), 4.17-$

$4.22(\mathrm{~m}, 1 \mathrm{H})$, 4.52-4.53 $(\mathrm{m}, 1 \mathrm{H})$, 7.02-7.07 $(\mathrm{m}, 1 \mathrm{H})$, 7.13-7.17 (m, 3H), 7.23-7.30 (m, 4H),

7.33-7.45 (m, 8H), 7.48-7.54 (m, 3H). ${ }^{13} \mathrm{C}\left\{{ }^{1} \mathrm{H}\right\} \operatorname{NMR}\left(125.8 \mathrm{MHz}, \mathrm{CD}_{2} \mathrm{Cl}_{2}\right): \delta 11.4,30.8(\mathrm{~d}, J$

$=5.0 \mathrm{~Hz}), 57.8(\mathrm{~d}, J=10.0 \mathrm{~Hz}), 78.1(\mathrm{~d}, J=7.7 \mathrm{~Hz}), 126.4,126.9,127.0,127.5,127.7(\mathrm{~d}$,

$J=9.8 \mathrm{~Hz}), 128.3,128.4(\mathrm{~d}, J=65.6 \mathrm{~Hz}), 130.1,130.3(\mathrm{~d}, J=2.1 \mathrm{~Hz}), 130.3(\mathrm{~d}, J=2.1$

$\mathrm{Hz}), 130.6(\mathrm{~d}, J=2.2 \mathrm{~Hz}), 131.3(\mathrm{~d}, J=52.9 \mathrm{~Hz}), 132.3(\mathrm{~d}, J=9.8 \mathrm{~Hz}), 132.6(\mathrm{~d}, J=8.8$

$\mathrm{Hz}), 133.7(\mathrm{~d}, J=9.8 \mathrm{~Hz}), 141.3(\mathrm{~d}, J=2.7 \mathrm{~Hz}), 143.0,146.7(\mathrm{~d}, J=9.6 \mathrm{~Hz}) .{ }^{31} \mathrm{P}\left\{{ }^{1} \mathrm{H}\right\} \mathrm{NMR}$

(121.5 MHz, $\mathrm{CD}_{2} \mathrm{Cl}_{2}$ ): $\delta+70.7$ (br.s). FTIR (neat): $\mathrm{v}_{\max } 3448,2961,2897,2388,1643,1604$, 
1535, 1493, 1446, 1157, 1064, 998, 951, 912, 886, 751, 697, $636 \mathrm{~cm}^{-1}$. HRMS (ESI/Q-

TOF) calcd for $\mathrm{C}_{28} \mathrm{H}_{31} \mathrm{BNOPNa}[\mathrm{M}+\mathrm{Na}]^{+}:$462.2129; found: 462.2120 .

4.3.7. $\quad\left(R_{p}\right)-N-[(1 R, 2 S)-2-H y d r o x y-1-m e t h y l-2-p h e n y l e t h y l], \quad N-($ methylamino)phenyl(2-

pyridyl) phosphine-borane 11r. This compound was synthesized by reaction of oxazaphospholidine-borane complex (-)-10a with 2-pyridinyllithium reagent. ${ }^{1} \mathrm{H}$ NMR (300 $\left.\mathrm{MHz}_{\mathrm{CDCl}}\right): \delta 0.40-1.70(\mathrm{~m}, 3 \mathrm{H}), 1.18(\mathrm{~d}, J=6.8 \mathrm{~Hz}, 3 \mathrm{H}), 2.64(\mathrm{~d}, J=8.5 \mathrm{~Hz}, 3 \mathrm{H}), 3.04-$ $3.06(\mathrm{~m}, 1 \mathrm{H}), 4.10-4.20(\mathrm{~m}, 1 \mathrm{H}), 4.82(\mathrm{dd}, J=5.2,5.0 \mathrm{~Hz}, 1 \mathrm{H}), 7.16-7.17(\mathrm{~m}, 2 \mathrm{H}), 7.28-$ $7.48(\mathrm{~m}, 9 \mathrm{H}), 7.76-7.85(\mathrm{~m}, 1 \mathrm{H}), 7.95-8.03(\mathrm{~m}, 1 \mathrm{H}), 8.79(\mathrm{~d}, J=3.3 \mathrm{~Hz}, 1 \mathrm{H}) .{ }^{13} \mathrm{C}\left\{{ }^{1} \mathrm{H}\right\} \mathrm{NMR}$ $\left(75.5 \mathrm{MHz}, \mathrm{CDCl}_{3}\right): \delta 13.7(\mathrm{~d}, J=1.6 \mathrm{~Hz}), 31.1,58.4(\mathrm{~d}, J=6.7 \mathrm{~Hz}), 78.2(\mathrm{~d}, J=5.9 \mathrm{~Hz})$, $124.9(\mathrm{~d}, J=2.4 \mathrm{~Hz}), 126.9,128.2(\mathrm{~d}, J=42.0 \mathrm{~Hz}), 128.5,128.6,129.2(\mathrm{~d}, J=26.0 \mathrm{~Hz})$, $130.3(\mathrm{~d}, J=72.0 \mathrm{~Hz}), 131.0(\mathrm{~d}, J=2.2 \mathrm{~Hz}), 132.3(\mathrm{~d}, J=7.2 \mathrm{~Hz}), 136.3(\mathrm{~d}, J=9.4 \mathrm{~Hz})$, 142.4, $149.9(\mathrm{~d}, J=12.6 \mathrm{~Hz}), 156.5(\mathrm{~d}, J=73.2 \mathrm{~Hz}) .{ }^{31} \mathrm{P}\left\{{ }^{1} \mathrm{H}\right\} \mathrm{NMR}\left(121.5 \mathrm{MHz}, \mathrm{CDCl}_{3}\right): \delta$ +69.6 (br.s). Anal. calcd for $\mathrm{C}_{21} \mathrm{H}_{26} \mathrm{BN}_{2} \mathrm{OP}$ : C 69.25, H 7.20, N 7.69; found C 69.14, H 7.25, N 7.95 .

4.3.8. $\quad\left(M, S_{p}\right)-(+)-N-[(1 S, 2 R)-2-(H y d r o x y-1-m e t h y l-2-p h e n y l e t h y l)], \quad N-$ methylamino-2(1,1'-binaphtyl)phenylphosphine-borane $11 \mathrm{v}$. To a solution of $(2 R, 4 S, 5 R)-3,4-$ dimethyl-2,5diphenyl-1,3,2-oxazaphospholidine-2-borane $(+)-10 \mathrm{a}(1.0 \mathrm{~g}, 3.5 \mathrm{mmol})$ in THF $(6 \mathrm{~mL})$ was added at $-78{ }^{\circ} \mathrm{C} 1,1^{\prime}$-binapht-2-yllithium. It was previously prepared by slow addition at -78 
${ }^{\circ} \mathrm{C}$ of $t$-butyllithium $(1.9 \mathrm{M}$ in hexane, $7.4 \mathrm{~mL}, 14 \mathrm{mmol})$ to a solution of $( \pm)$-2-bromo-1,1'-

binaphtyl $17(2.3 \mathrm{~g}, 7 \mathrm{mmol})$ in $\mathrm{Et}_{2} \mathrm{O}(3.5 \mathrm{~mL})$ and stirring at this temperature during one hour. The reaction mixture was stirred overnight until it reached room temperature, and 20 $\mathrm{mL}$ of water was added. The aqueous phase was extracted with $\mathrm{CH}_{2} \mathrm{Cl}_{2}(3 \times 20 \mathrm{~mL})$. The organic extracts were dried over anhydrous $\mathrm{MgSO}_{4}$ and the solvent was evaporated. The crude product was purified by chromatography on silica gel using $\mathrm{CH}_{2} \mathrm{Cl}_{2}$ as eluent to give the aminophosphine-borane $11 \mathrm{v}$ as a mixture of diastereoisomers in 85:15 ratio. Recrystallization in ethyl acetate afforded the titled compound as only one diastereoisomer. The X-ray structure and the data were reported in the SI. White solid $(0.72 \mathrm{~g}, 38 \%$ yield $) . R_{\mathrm{f}}$ $=0.41\left(\mathrm{CH}_{2} \mathrm{Cl}_{2}\right) ;[\alpha]_{\mathrm{D}}{ }^{20}=+18.0\left(\mathrm{c} 0.3, \mathrm{CHCl}_{3}\right) .{ }^{1} \mathrm{H}$ NMR $\left(500 \mathrm{MHz}, \mathrm{CDCl}_{3}\right): \delta$ 0.40-1.38 (m, $3 \mathrm{H}), 0.46(\mathrm{~d}, J=7.1 \mathrm{~Hz}, 3 \mathrm{H}), 2.56(\mathrm{~d}, J=7.7 \mathrm{~Hz}, 3 \mathrm{H}), 3.71-3.74(\mathrm{~m}, 1 \mathrm{H}), 4.86-4.87(\mathrm{~m}$, 1H), $7.02(\mathrm{~d}, J=8.4 \mathrm{~Hz}, 1 \mathrm{H}), 7.12-7.27(\mathrm{~m}, 10 \mathrm{H}), 7.35-7.43(\mathrm{~m}, 4 \mathrm{H}), 7.52(\mathrm{t}, J=7.5 \mathrm{~Hz}$, 1H), 7.57-7.62 (m, 3H), 7.82-7.85 (m, 2H), 7.91-7.92 (m, 2H). ${ }^{13} \mathrm{C}\{1 \mathrm{H}\}$ NMR $(125.8 \mathrm{MHz})$, $\left.\mathrm{CDCl}_{3}\right): \delta 9.7(\mathrm{~d}, J=5.5 \mathrm{~Hz}), 32.6(\mathrm{~d}, J=3.5 \mathrm{~Hz}), 57.9(\mathrm{~d}, J=9.4 \mathrm{~Hz}), 78.9,125.1,125.5$, 125.6, 125.7, 126.7, 126.9, 127.1, $127.5(\mathrm{~d}, J=9.8 \mathrm{~Hz}), 127.6,127.8,127.9,128.1,128.2$, 128.5, $129.3(d, J=10.7 \mathrm{~Hz}), 129.8,130.3(d, J=2.0 \mathrm{~Hz}), 131.9(\mathrm{~d}, J=9.8 \mathrm{~Hz}), 133.2$, 133.4, 133.7, 134.0 (d, $J=9.7 \mathrm{~Hz}), 134.1,134.2$ (d, $J=7.2 \mathrm{~Hz}), 134.8(\mathrm{~d}, J=4.0 \mathrm{~Hz})$, 142.6, $\left.144.2(\mathrm{~d}, J=9.9 \mathrm{~Hz}) .{ }^{31} \mathrm{P}\left\{{ }^{1} \mathrm{H}\right\} \operatorname{NMR}(202.5 \mathrm{MHz}), \mathrm{CDCl}_{3}\right): \delta+71.7$ (br.s). FTIR 
(neat): $v_{\max } 3520,3078,2830,2380,2365,1450,1437,1385,1367,1163,1106,1062$, 1022, 998, 883, $822 \mathrm{~cm}^{-1}$. HRMS (ESI/Q-TOF) calcd for $\mathrm{C}_{36} \mathrm{H}_{35} \mathrm{BNOPNa}[\mathrm{M}+\mathrm{Na}]^{+}$: 562.2448; found: 562.2446 .

\subsection{Synthesis of the AMPP*-diboranes 12a-w with P-chirogenic aminophosphine}

moieties.

4.4.1. Typical procedures: AMPP*-diborane complexes 12 were obtained either according to a one-pot procedure from the oxazaphospholidine-2-borane 10 (Method A), or by deprotonation of the isolated aminophosphine-borane 11 (Method B).

4.4.1.1. From oxazaphospholidine borane 10 (Method $A)$. To a solution of 3,4-dimethyl5-phenyl-1,3,2-oxazaphospholidine-2-borane $10(3.5 \mathrm{mmol})$ in THF $(6 \mathrm{~mL})$ was slowly added at $-78{ }^{\circ} \mathrm{C}$ the organolithium reagent $(7 \mathrm{mmol})$. The temperature reaction was slowly warmed to $0{ }^{\circ} \mathrm{C}$ and the solution was stirred until the starting material was completely consumed. Chlorophosphine $\mathrm{R}_{2}{ }_{2} \mathrm{PCl}\left(7 \mathrm{mmol} ; \mathrm{R}^{\prime}=\mathrm{Ph}, \alpha-\mathrm{Np}\right.$ or 3,5-Xyl) was added and the mixture was stirred for $2 \mathrm{~h}$. Borane-dimethylsulfide complex $(2.7 \mathrm{~mL}, 28 \mathrm{mmol})$ was slowly added at $0{ }^{\circ} \mathrm{C}$ and the reaction mixture was stirred overnight until the solution reached room temperature. Water $(20 \mathrm{~mL})$ was added and the aqueous phase was extracted with $\mathrm{CH}_{2} \mathrm{Cl}_{2}(3 \times 20 \mathrm{~mL})$. The organic extracts were dried over anhydrous $\mathrm{MgSO}_{4}$ and the 
solvent was evaporated. The crude product was purified by chromatography on silica gel and, in some cases, by recrystallization to afford the desired AMPP*-diboranes 12 .

4.4.1.2. From aminophosphine-borane 11 (Method B). To a solution of aminophosphineborane $11(0.5 \mathrm{mmol})$ in THF $(1 \mathrm{~mL})$ was slowly added at $-78^{\circ} \mathrm{C} n$-BuLi $(0.6 \mathrm{mmol})$. After stirring during one hour at $-78{ }^{\circ} \mathrm{C}$, chlorophosphine $\mathrm{R}_{2}^{\prime} \mathrm{PCl}(1.1 \mathrm{mmol})$ was added and the resulting mixture was stirred until the solution reached room temperature $(\sim 5 \mathrm{~h})$. Boranedimethylsulfide complex $(4 \mathrm{mmol})$ was added at $0{ }^{\circ} \mathrm{C}$ and the solution was stirred overnight before hydrolysis with water $(10 \mathrm{~mL})$. The work-up is similar as described above.

4.4.2. The $E P H O S_{-}{ }^{8}$ and the $A M P P^{*}$-diborane complexes $12 \mathrm{a}-\mathrm{c},{ }^{9 \mathrm{a}, \mathrm{b}} 12 \mathrm{f}-\mathrm{h},{ }^{9 \mathrm{~b}} \quad 12 \mathrm{j},{ }^{9 \mathrm{a}, \mathrm{b}, 10}$ $12 \mathrm{k}, 12 \mathrm{l},{ }^{9 \mathrm{~b}} 12 \mathrm{u}^{9 \mathrm{c}}$ and $15 \mathrm{e},{ }^{9 a}$ were synthetized as described in literature.

\subsection{3. $\left(S_{p}\right)-(-)-N-[(1 R, 2 S)-2-(D i p h e n y / p h o s p h i n i t o-b o r a n e)-1-m e t h y l-2-p h e n y l e t h y l], \quad N-$} methyl amino(o-biphenyl)pheny/phosphine-borane 12i. The synthesis of 12i was achieved using the method $\mathrm{A}$ (as described above) by reaction of the complex (-)-10b (1.26 $\mathrm{g}, 3.5$ $\mathrm{mmol})$ in THF $(6 \mathrm{~mL})$ at $-78{ }^{\circ} \mathrm{C}$ with phenyllithium $(1.8 \mathrm{M}$ in dibutylether, $3.9 \mathrm{~mL}, 7 \mathrm{mmol})$. The ring opening product [11i] was then trapped by $\mathrm{Ph}_{2} \mathrm{PCl}$. The purification was achieved by chromatography on silica gel using petroleum ether/ $\mathrm{CH}_{2} \mathrm{Cl}_{2} \quad 1: 1$ as eluent and recrystallization in hexane/dichloromethane to give the AMPP*-diborane $12 \mathbf{i}$ as a white solid ( $1.16 \mathrm{~g}, 52 \%$ yield). X-ray quality crystals were grown by slow evaporation of a 
mixture of $\mathrm{CH}_{2} \mathrm{Cl}_{2}$ and hexane. The structure and the data were reported in the $\mathrm{SI} . R_{\mathrm{f}}=$ 0.62 (petroleum ether $\left./ \mathrm{CH}_{2} \mathrm{Cl}_{2} 1: 1\right) ; \mathrm{Mp}=206-208{ }^{\circ} \mathrm{C} ;[\alpha]_{D}{ }^{20}=-52.2\left(\mathrm{c} 0.4, \mathrm{CHCl}_{3}\right) .{ }^{1} \mathrm{H}$ NMR $\left(500 \mathrm{MHz}, \mathrm{CD}_{2} \mathrm{Cl}_{2}\right): \delta 0.56-1.73(\mathrm{~m}, 6 \mathrm{H}), 1.03(\mathrm{~d}, J=6.6 \mathrm{~Hz}, 3 \mathrm{H}), 2.19(\mathrm{~d}, J=7.7 \mathrm{~Hz}, 3 \mathrm{H})$, 4.69-4.77 (m, 1H), $5.42(\mathrm{t}, J=9.1 \mathrm{~Hz}, 1 \mathrm{H}), 6.27(\mathrm{ddd}, J=12.2,2.1,1.2 \mathrm{~Hz}, 1 \mathrm{H}), 6.89-6.96$ $(m, 4 H), 7.07-7.24(m, 8 H), 7.32-7.42(m, 9 H), 7.48-7.56(m, 5 H), 7.73-7.78(m, 2 H)$. ${ }^{13} \mathrm{C}\left\{{ }^{1} \mathrm{H}\right\} \operatorname{NMR}\left(125.8 \mathrm{MHz}, \mathrm{CD}_{2} \mathrm{Cl}_{2}\right): \delta 15.2,29.2(\mathrm{~d}, J=4.9 \mathrm{~Hz}), 57.2(\mathrm{dd}, J=10.0,8.9 \mathrm{~Hz})$, $83.5(\mathrm{dd}, J=10.4,2.7 \mathrm{~Hz}), 126.8,126.9,127.1(\mathrm{~d}, J=9.5 \mathrm{~Hz}), 127.4(\mathrm{~d}, J=10.1 \mathrm{~Hz})$, 127.7, 127.9, 128.0, 128.3, $128.5(\mathrm{~d}, J=10.7 \mathrm{~Hz}), 128.7,129.0,129.0(\mathrm{~d}, J=54.1 \mathrm{~Hz})$, 130.0, $130.1(\mathrm{~d}, J=2.4 \mathrm{~Hz}), 130.5(\mathrm{~d}, J=1.8 \mathrm{~Hz}), 131.0(\mathrm{~d}, J=10.7 \mathrm{~Hz}), 131.4(\mathrm{~d}, J=1.8$ $\mathrm{Hz}), 131.5,131.6,131.7$ (d, $J=1.8 \mathrm{~Hz}), 132.0$ (d, $J=59.4 \mathrm{~Hz}), 132.3(\mathrm{~d}, J=8.9 \mathrm{~Hz}), 132.5$ (d, $J=10.1 \mathrm{~Hz}), 132.8,132.9(\mathrm{~d}, J=7.7 \mathrm{~Hz}), 138.4,140.5(\mathrm{~d}, J=2.6 \mathrm{~Hz}), 146.4(\mathrm{~d}, J=$ 11.0 Hz). ${ }^{31} \mathrm{P}\left\{{ }^{1} \mathrm{H}\right\} \operatorname{NMR}\left(202.5 \mathrm{MHz}, \mathrm{CD}_{2} \mathrm{Cl}_{2}\right): \delta+69.7-70.0(\mathrm{~m}),+106.5-106.9(\mathrm{~m}) . \mathrm{FTIR}$ (neat): $v_{\max } 3054,2933,2393,2353,1457,1437,1220,1159,1135,1115,1066,1011$, 974, 892, 864, 760, 738, $715 \mathrm{~cm}^{-1}$. HRMS (ESI/Q-TOF) calcd for $\mathrm{C}_{40} \mathrm{H}_{43} \mathrm{~B}_{2} \mathrm{P}_{2} \mathrm{NONa}$ $[\mathrm{M}+\mathrm{Na}]^{+}$: 660.2911; found: 660.2896. Anal. calcd for $\mathrm{C}_{40} \mathrm{H}_{43} \mathrm{~B}_{2} \mathrm{P}_{2} \mathrm{NO}: \mathrm{C} 75.38, \mathrm{H} 6.80$, N 2.20; found: C 75.03, H 6.92, N 2.29.

4.4.4. ( $\left.R_{\mathrm{p}}\right)-(-)-N-[(1 R, 2 S)-2-(D i p h e n y /$ phosphinito-borane)-1-methyl-2-phenylethyl], $\quad N$ methyl amino(2-isopropoxyphenyl)pheny/phosphine-borane $12 \mathrm{~m}$. The synthesis of $12 \mathrm{~m}$ 
was achieved using the method A (as described above), by reaction of the complex (-)-10a

$(1.0 \mathrm{~g}, 3.5 \mathrm{mmol})$ with the 2-i-propyloxyphenyllithium previously prepared from 1-bromo-2- propyloxybenzene $(1.5 \mathrm{~g}, 7 \mathrm{mmol})$ in THF $(3.5 \mathrm{~mL})$ and $s$-BuLi $(1.4 \mathrm{M}$ in cyclohexane, 5.0 $\mathrm{mL}, 7 \mathrm{mmol})$. The ring opening product $[11 \mathrm{~m}]$ was then trapped by $\mathrm{Ph}_{2} \mathrm{PCl}$. The purification was achieved by column chromatography on silica gel using petroleum ether/toluene (1:1) as eluent. White crystals $\left(1.06 \mathrm{~g}, 54 \%\right.$ yield). $R_{\mathrm{f}}=0.10$ (petroleum ether/toluene $\left.1: 1\right) ; \mathrm{Mp}=$ $172-174{ }^{\circ} \mathrm{C} ;[\alpha]_{\mathrm{D}}{ }^{20}=-50.7\left(\mathrm{c} 1.5, \mathrm{CHCl}_{3}\right) .{ }^{1} \mathrm{H}$ NMR $\left(400 \mathrm{MHz}, \mathrm{CDCl}_{3}\right): \delta 0.33-1.61(\mathrm{~m}, 6 \mathrm{H})$, $0.68(\mathrm{~d}, J=6.2 \mathrm{~Hz}, 3 \mathrm{H}), 0.78(\mathrm{~d}, J=6.2 \mathrm{~Hz}, 3 \mathrm{H}), 1.25(\mathrm{~d}, J=6.2 \mathrm{~Hz}, 3 \mathrm{H}), 2.37(\mathrm{~d}, J=7.8$ $\mathrm{Hz}, 3 \mathrm{H}), 4.27$ (hept, $J=6.2 \mathrm{~Hz}, 1 \mathrm{H}), 4.52-4.59(\mathrm{~m}, 1 \mathrm{H}), 5.32(\mathrm{t}, J=8.8 \mathrm{~Hz}, 1 \mathrm{H}), 6.50(2 \mathrm{~d}, J$ $=7.7 \mathrm{~Hz}, 2 \mathrm{H}), 6.69(\mathrm{dd}, J=4.2,2.3 \mathrm{~Hz}, 1 \mathrm{H}), 6.90-6.95(\mathrm{~m}, 3 \mathrm{H}), 7.00-7.44(\mathrm{~m}, 15 \mathrm{H}), 7.61-$ $7.67(\mathrm{~m}, 2 \mathrm{H}), 7.80(\mathrm{ddd}, J=1.5,7.6,13.8 \mathrm{~Hz}, 1 \mathrm{H}) .{ }^{13} \mathrm{C}\left\{{ }^{1} \mathrm{H}\right\}$ NMR $\left(100.6 \mathrm{MHz}, \mathrm{CDCl}_{3}\right): \delta$ 16.1, 20.6, 21.1, $29.8(d, J=5.1 \mathrm{~Hz}), 57.5(\mathrm{dd}, J=8.3,11.3 \mathrm{~Hz}), 69.0,83.5$ (dd, $J=2.9$, $11.5 \mathrm{~Hz}), 111.7(\mathrm{~d}, J=4.1 \mathrm{~Hz}), 118.1(\mathrm{~d}, J=54.2 \mathrm{~Hz}), 120.1(\mathrm{~d}, J=10.8 \mathrm{~Hz}), 127.6(\mathrm{~d}, J=$ 11.2 Hz), $127.8(d, J=10.6 \mathrm{~Hz}), 128.1,128.3,128.5(\mathrm{~d}, J=10.6 \mathrm{~Hz}), 128.8,129.3(\mathrm{~d}, J=$ 2.1 Hz), $130.2(d, J=11.2 \mathrm{~Hz}), 131.1(\mathrm{~d}, J=11.3 \mathrm{~Hz}), 131.3(\mathrm{~d}, J=2.0 \mathrm{~Hz}), 131.6(\mathrm{~d}, J=$ 11.7 Hz), 131.7 (d, J=2.0 Hz), $132.2(d, J=7.8 \mathrm{~Hz}), 132.3(\mathrm{~d}, J=76.4 \mathrm{~Hz}), 132.9,133.2$ $(\mathrm{d}, J=1.5 \mathrm{~Hz}), 136.1(\mathrm{~d}, J=14.1 \mathrm{~Hz}), 138.1,158.6 .{ }^{31} \mathrm{P}\left\{{ }^{1} \mathrm{H}\right\} \operatorname{NMR}\left(161.9 \mathrm{MHz}, \mathrm{CDCl}_{3}\right)$ : $\delta+68.3$ (br.s), +106.4 (br.s). FTIR (neat): $v_{\max }$ 3080-3010, 2978-2819, 2391, 2378, 2346, 
1587, 1572, 1471, 1456, 1437, 1383, 1372, 1275, 1244, 1222, 1164, 1132, 1113, 1061, 1013, 983, 952, 890, 865, 768, 752, 735, 714, $694 \mathrm{~cm}^{-1}$. HRMS (ESI/Q-TOF) calcd for $\mathrm{C}_{37} \mathrm{H}_{44} \mathrm{~B}_{2} \mathrm{NO}_{2} \mathrm{P}_{2}[\mathrm{M}-\mathrm{H}]^{+}:$618.3033; found 618.3043. Anal. calcd for $\mathrm{C}_{37} \mathrm{H}_{45} \mathrm{~B}_{2} \mathrm{NO}_{2} \mathrm{P}_{2}$ : C 71.75, H 7.32, N 2.26; found C 72.02, H 7.56, N 2.32.

4.4.5. (Rp)-(-)-N-[(1R,2S)-2-(Diphenylphosphinito-borane)-1-methyl-2-phenylethyl], $\quad N$ methyl amino(2-benzyloxyphenyl)phenylphosphine-borane $12 \mathrm{n}$. The synthesis of $12 \mathrm{n}$ was achieved using the method $A$ (as described above), by reaction of the complex (-)-10a (1.0 $\mathrm{g}, 3.5 \mathrm{mmol}$ ) with the 2-benzyloxyphenyllithium reagent, previously prepared using 2benzyloxybromobenzene $(1.8 \mathrm{~g}, 7 \mathrm{mmol})$ in THF $(3.5 \mathrm{~mL})$ and $s$-BuLi $(1.4 \mathrm{M}$ in cyclohexane, $5.0 \mathrm{~mL}, 7 \mathrm{mmol})$. The ring opening product [11 $\mathrm{n}$ ] was then trapped by $\mathrm{Ph}_{2} \mathrm{PCl}$. The purification was achieved by column chromatography on silica gel using petroleum ether/toluene $(1: 1)$ as eluent. White crystals $(1.05 \mathrm{~g}, 45 \%$ yield $) . R_{\mathrm{f}}=0.10$ (petroleum ether/toluene 1:1); $\mathrm{Mp}=140-142{ }^{\circ} \mathrm{C} ;[\mathrm{a}]_{\mathrm{D}}{ }^{20}=-36.5\left(\mathrm{c} 1.9, \mathrm{CHCl}_{3}\right) .{ }^{1} \mathrm{H} \mathrm{NMR}(300$ $\left.\mathrm{MHz}, \mathrm{CDCl}_{3}\right): \delta 0.20-1.60(\mathrm{~m}, 6 \mathrm{H}), 1.22(\mathrm{~d}, J=6.6 \mathrm{~Hz}, 3 \mathrm{H}), 2.27(\mathrm{~d}, J=7.8 \mathrm{~Hz}, 3 \mathrm{H}), 4.45-$ $4.60(\mathrm{~m}, 1 \mathrm{H}), 4.69(\mathrm{~s}, 2 \mathrm{H}), 5.27(\mathrm{t}, J=9.2 \mathrm{~Hz}, 1 \mathrm{H}), 6.53(\mathrm{dd}, J=7.4,11.7 \mathrm{~Hz}, 2 \mathrm{H}), 6.63(\mathrm{~d}$, $J=6.9 \mathrm{~Hz}, 2 \mathrm{H}), 6.85-7.41(\mathrm{~m}, 22 \mathrm{H}), 7.60-7.80(\mathrm{~m}, 3 \mathrm{H}) .{ }^{13} \mathrm{C}\left\{{ }^{1} \mathrm{H}\right\} \mathrm{NMR}\left(75.5 \mathrm{MHz}, \mathrm{CDCl}_{3}\right): \delta$ 15.9, 29.8 (d, $J=4.5 \mathrm{~Hz}), 57.5$ (br.s), 70.1, 83.4 (d, $J=9.8 \mathrm{~Hz}), 112.3$ (d, $J=4.5 \mathrm{~Hz})$, 118.2, 118.9, $121.2(\mathrm{~d}, J=11.3 \mathrm{~Hz}), 126.8,127.6,127.8,128.0(\mathrm{~d}, J=9.1 \mathrm{~Hz}), 128.2$, 
128.3, 128.5 (d, $J=10.6 \mathrm{~Hz}), 128.8,129.6(\mathrm{~d}, J=2.0 \mathrm{~Hz}), 130.4(\mathrm{~d}, J=10.6 \mathrm{~Hz}), 131.0$, 131.2, $131.3(\mathrm{~d}, J=2.0 \mathrm{~Hz}), 131.5,131.7,132.0,132.2(\mathrm{~d}, J=8.3 \mathrm{~Hz}), 132.9,133.5$, 135.8, $136.0(\mathrm{~d}, J=13.6 \mathrm{~Hz}), 138.0,159.9 .{ }^{31} \mathrm{P}\left\{{ }^{1} \mathrm{H}\right\} \operatorname{NMR}\left(121.5 \mathrm{MHz}, \mathrm{CDCl}_{3}\right): \delta+68.7$ (br.s), +106.7 (br.s). FTIR (neat): $v_{\max }$ 3083-3040, 2976-2854, 2344, 2299, 1570, 1546, $1465,1437,1363,1250,1223,1130,1115,1066,1043,999,973,922,914,860,831,740$, 714, $694 \mathrm{~cm}^{-1}$. HRMS (ESI/Q-TOF) calcd for $\mathrm{C}_{41} \mathrm{H}_{46} \mathrm{~B}_{2} \mathrm{P}_{2} \mathrm{NO}_{2}[\mathrm{M}+\mathrm{H}]^{+}$: 668.3190; found: 668.3195.

4.4.6. (Rp)-(-)-N-[(1R,2S)-2-(Diphenylphosphinito-borane)-1-methyl-2-phenylethyl], $\quad N$ methyl amino(3,5-dimethylphenyl)phenylphosphine-borane 120 . The synthesis of 120 was achieved using the method $A$ (as described above), by reaction of the complex (-)-10a (1.0 g, $3.5 \mathrm{mmol}$ ) with the 3,5-dimethylphenyllithium reagent previously prepared using 1bromo-3,5-dimethylbenzene $(0.95 \mathrm{~mL}, 7 \mathrm{mmol})$ in THF $(3.5 \mathrm{~mL})$ and $s$-BuLi $(1.4 \mathrm{M}$ in cyclohexane, $5.0 \mathrm{~mL}, 7 \mathrm{mmol}$ ). The ring opening product [110] was then trapped by $\mathrm{Ph}_{2} \mathrm{PCl}$. The purification was achieved by column chromatography on silica gel using petroleum ether/toluene $(7: 3)$ as eluent. White crystals $(0.62 \mathrm{~g}, 30 \%$ yield $) . R_{\mathrm{f}}=0.10$ (petroleum ether/toluene 7:3); $\mathrm{Mp}=168-170{ }^{\circ} \mathrm{C} ;[\alpha]_{\mathrm{D}}^{20}=-78.8$ (c 1.0, $\mathrm{CH}_{2} \mathrm{Cl}_{2}$ ). ${ }^{1} \mathrm{H}$ NMR (500 MHz, $\left.\mathrm{CDCl}_{3}\right): \delta 0.50-1.81(\mathrm{~m}, 6 \mathrm{H}), 1.37(\mathrm{~d}, J=6.2 \mathrm{~Hz}, 3 \mathrm{H}), 2.32(\mathrm{~s}, 6 \mathrm{H}), 2.33(\mathrm{~d}, J=$ $8.5 \mathrm{~Hz}, 3 \mathrm{H}), 4.58-4.64(\mathrm{~m}, 1 \mathrm{H}), 5.40(\mathrm{t}, J=9.2 \mathrm{~Hz}, 3 \mathrm{H}), 6.64-6.68(\mathrm{~m}, 2 \mathrm{H}), 7.09-7.17(\mathrm{~m}$, 
$10 \mathrm{H}), 7.26-7.40(\mathrm{~m}, 6 \mathrm{H}), 7.47-7.54(\mathrm{~m}, 3 \mathrm{H}), 7.73-7.77(\mathrm{~m}, 2 \mathrm{H}) .{ }^{13} \mathrm{C}\left\{{ }^{1} \mathrm{H}\right\} \mathrm{NMR}(125.8 \mathrm{MHz}$, $\left.\mathrm{CDCl}_{3}\right): \delta 16.3,21.4,29.4(\mathrm{~d}, J=4.5 \mathrm{~Hz}), 57.3(\mathrm{dd}, J=11.2,8.8 \mathrm{~Hz}), 83.3(\mathrm{dd}, J=9.0,2.5$ Hz), $127.8(d, J=10.6 \mathrm{~Hz}), 127.9(\mathrm{~d}, J=11.1 \mathrm{~Hz}), 128.2,128.5(\mathrm{~d}, J=9.2 \mathrm{~Hz}), 128.6$, 128.7, 129.8 (d, J=34.2 Hz), 130.1 (d, $J=10.3 \mathrm{~Hz}), 130.2(\mathrm{~d}, J=1.9 \mathrm{~Hz}), 130.4(\mathrm{~d}, J=$ 20.4 Hz), 131.0 (d, J=11.2 Hz), 131.3 (d, $J=2.2 \mathrm{~Hz}), 131.6,131.7,131.8$ (d, $J=9.8 \mathrm{~Hz})$, $132.1(\mathrm{~d}, J=6.5 \mathrm{~Hz}), 132.7,133.0(\mathrm{~d}, J=1.6 \mathrm{~Hz}), 137.9,138.1(\mathrm{~d}, J=5.9 \mathrm{~Hz}) .{ }^{31} \mathrm{P}\left\{{ }^{1} \mathrm{H}\right\}$ $\operatorname{NMR}\left(202.5 \mathrm{MHz}, \mathrm{CDCl}_{3}\right): \delta+71.2$ (br.s), +106.8 (br.s). FTIR (neat): $\mathrm{v}_{\max } 3062-2817,2394-$ $2249,1454,1436,1222,1161,1128,1108,1063,1011,1000,991,958,894,864,855$, 769, 761, 753, 736, 712, $691 \mathrm{~cm}^{-1}$. HRMS (ESI/Q-TOF) calcd for $\mathrm{C}_{36} \mathrm{H}_{42} \mathrm{~B}_{2} \mathrm{NOP}_{2}[\mathrm{M}-\mathrm{H}]^{+}$: 588.2928; found 588.2934. Anal. calcd for $\mathrm{C}_{36} \mathrm{H}_{43} \mathrm{~B}_{2} \mathrm{NOP}_{2}$ : C 73.37, H 7.35, N 2.38; found: C 73.26, H 7.46, N 2.43.

4.4.7. (R $\left.R_{p}\right)-(-)-N-[(1 R, 2 S)-2-(D i p h e n y l p h o s p h i n i t o-b o r a n e)-1-m e t h y l-2-p h e n y l e t h y l], \quad N-$ methyl amino(3,5-di-t-butylphenyl)phenylphosphine-borane 12p. The synthesis of $12 \mathrm{p}$ was achieved using the method $A$ (as described above), by reaction of the complex (-)-10a (1.0 g, $3.5 \mathrm{mmol}$ ) with the 3,5-di-t-butylphenyllithium previously prepared from 1-bromo-3,5-di- $t$ butylbenzene $(1.9 \mathrm{~g}, 7 \mathrm{mmol})$ in THF $(3.5 \mathrm{~mL})$ and $t$-BuLi $(1.9 \mathrm{M}$ in hexane, $7.4 \mathrm{~mL}, 14$ $\mathrm{mmol})$. The ring opening product [11p] was then trapped by $\mathrm{Ph}_{2} \mathrm{PCl}$. The purification was achieved by column chromatography on silica gel using petroleum ether/ $\mathrm{CH}_{2} \mathrm{Cl}_{2}(2: 1)$ as 
eluent. White solid $\left(1.67 \mathrm{~g}, 71 \%\right.$ yield). $R_{\mathrm{f}}=0.68$ (petroleum ether $\left./ \mathrm{CH}_{2} \mathrm{Cl}_{2} 2: 1\right) ;[\alpha]_{D}^{20}=-$

63.4 (c 0.4, $\left.\mathrm{CHCl}_{3}\right) .{ }^{1} \mathrm{H}$ NMR (500 MHz, $\left.\mathrm{CDCl}_{3}\right): \delta$ 0.59-1.52 (m, 6H), $1.30(\mathrm{~s}, 18 \mathrm{H}), 1.42$ (d, J=6.7 Hz, 3H), $2.30(\mathrm{~d}, J=7.5 \mathrm{~Hz}, 3 \mathrm{H}), 4.66-4.72(\mathrm{~m}, 1 \mathrm{H}), 5.42(\mathrm{t}, J=9.6 \mathrm{~Hz}, 1 \mathrm{H})$, 6.67-6.71 (m, 2H), 7.08-7.20 (m, 7H), 7.28-7.36 (m, 4H), 7.40-7.42 (m, 4H), 7.48-7.54 (m, 4H), 7.75-7.78 (m, 2H). ${ }^{13} \mathrm{C}\left\{{ }^{1} \mathrm{H}\right\} \operatorname{NMR}\left(125.8 \mathrm{MHz}, \mathrm{CDCl}_{3}\right): \delta 16.1,29.3(\mathrm{~d}, J=4.4 \mathrm{~Hz})$, 31.3, 35.0, $57.4(\mathrm{t}, J=9.7 \mathrm{~Hz}), 83.2(\mathrm{~d}, J=7.3 \mathrm{~Hz}), 124.9,126.8(\mathrm{~d}, J=11.9 \mathrm{~Hz}), 127.8$, $127.9(\mathrm{~d}, J=1.2 \mathrm{~Hz}), 128.2,128.4,128.5(\mathrm{~d}, J=10.8 \mathrm{~Hz}), 128.8,129.3(\mathrm{~d}, J=58.6 \mathrm{~Hz})$, $130.1(\mathrm{~d}, J=70.6 \mathrm{~Hz}), 130.2,131.1(\mathrm{~d}, J=11.0 \mathrm{~Hz}), 131.3,131.6-131.7(\mathrm{~m}), 131.8,132.2$ $(\mathrm{d}, J=8.8 \mathrm{~Hz}), 132.8,138.2,150.7(\mathrm{~d}, J=9.6 \mathrm{~Hz}) .{ }^{31} \mathrm{P}\left\{{ }^{1} \mathrm{H}\right\} \operatorname{NMR}\left(202.5 \mathrm{MHz}, \mathrm{CDCl}_{3}\right): \delta$ +72.6 (br.s), +106.9 (br.s). FTIR (neat): $v_{\max }$ 3070-2810, 2391, 2375, 2339, 1585, 1573, 1473, 1435, 1242, 1163, 1153, 1100, 1088, 999, 965, 873, $797 \mathrm{~cm}^{-1}$. HRMS (ESI/Q-TOF) calcd for $\mathrm{C}_{42} \mathrm{H}_{55} \mathrm{~B}_{2} \mathrm{NOP}_{2} \mathrm{Na}[\mathrm{M}+\mathrm{Na}]^{+}:$696.3854; found: 696.3834 .

4.4.8. ( $\left(R_{p}\right)-(-)-N-[(1 R, 2 S)-2-(D i p h e n y l p h o s p h i n i t o-b o r a n e)-1-m e t h y l-2-p h e n y l e t h y l], \quad N-$ methyl amino(3,5-di-t-butyl-4-methoxyphenyl)phenylphosphine-borane 12q. The synthesis of $12 q$ was achieved using the method $A$ (as described above), by reaction of the complex (-)-10a (1.0 g, $3.5 \mathrm{mmol})$ with the 3,5-di-t-butyl-4-methoxyphenyllithium previously prepared from bromo-3,5-di(t-butyl)-4-methoxybenzene $(2.1 \mathrm{~g}, 7 \mathrm{mmol})$ in THF $(3.5 \mathrm{~mL})$ and $s$-BuLi (1.4 $\mathrm{M}$ in hexane, $5.0 \mathrm{~mL}, 7 \mathrm{mmol}$ ). The ring opening product [11q] was then trapped by 
$\mathrm{Ph}_{2} \mathrm{PCl}$. The purification was performed by column chromatography on silica gel using petroleum ether/toluene $(7: 3)$ as eluent. White solid $(0.49 \mathrm{~g}, 20 \%$ yield $) . R_{\mathrm{f}}=0.10$ (petroleum ether/toluene 7:3); $\mathrm{Mp}=166-168{ }^{\circ} \mathrm{C} ;[\alpha]_{D}{ }^{20}=-75.3\left(\mathrm{c} 1.1, \mathrm{CHCl}_{3}\right) .{ }^{1} \mathrm{H}$ NMR $(500$ $\left.\mathrm{MHz}, \mathrm{CDCl}_{3}\right): \delta 0.48-1.78(\mathrm{~m}, 6 \mathrm{H}), 1.37(\mathrm{~s}, 18 \mathrm{H}), 1.39(\mathrm{~d}, J=6.8 \mathrm{~Hz}, 3 \mathrm{H}), 2.28(\mathrm{~d}, J=8.0$ $\mathrm{Hz}, 3 \mathrm{H}), 3.72(\mathrm{~s}, 3 \mathrm{H}), 4.62-4.69(\mathrm{~m}, 1 \mathrm{H}), 5.39(\mathrm{t}, J=9.4 \mathrm{~Hz}, 1 \mathrm{H}), 6.64-6.68(\mathrm{~m}, 2 \mathrm{H}), 7.06-$ 7.18 (m, 7H), 7.27-7.34 (m, 4H), 7.38-7.43 (m, 4H), 7.47-7.54 (m, 3H), 7.73-7.77 (m, 2H). ${ }^{13} \mathrm{C}\left\{{ }^{1} \mathrm{H}\right\} \operatorname{NMR}\left(125.8 \mathrm{MHz}, \mathrm{CDCl}_{3}\right): \delta 16.2,29.2(\mathrm{~d}, J=4.7 \mathrm{~Hz}), 31.9,36.0,57.3(\mathrm{dd}, J=$ 11.1, 9.4 Hz), 64.3, 83.3 (dd, $J=8.7,2.5 \mathrm{~Hz}), 123.5(\mathrm{~d}, J=61.9 \mathrm{~Hz}), 127.8(\mathrm{~d}, J=9.9 \mathrm{~Hz})$, 128.2, 128.4, 128.6 (d, $J=9.9 \mathrm{~Hz}), 128.7,130.1$ (d, $J=71.8 \mathrm{~Hz}), 130.2(\mathrm{~d}, J=2.2 \mathrm{~Hz})$, $131.1(\mathrm{~d}, J=11.1 \mathrm{~Hz}), 131.2(\mathrm{~d}, J=12.1 \mathrm{~Hz}), 131.4(\mathrm{~d}, J=1.9 \mathrm{~Hz}), 131.6-131.7(\mathrm{~m}), 132.1$ (d, $J=10.2 \mathrm{~Hz}), 132.7,138.1,143.7(\mathrm{~d}, J=10.4 \mathrm{~Hz}), 161.9(\mathrm{~d}, J=2.5 \mathrm{~Hz}) .{ }^{31} \mathrm{P}\left\{{ }^{1} \mathrm{H}\right\} \mathrm{NMR}$ (202.5 MHz, $\mathrm{CDCl}_{3}$ ): $\delta+71.6$ (br.s), +106.9 (br.s). FTIR (neat): $\mathrm{v}_{\max }$ 3059-3008, 2981-2869, $2375,2344,1455,1437,1410,1395,1264,1230,1144,1118,1065,1011,999,972,962$, 893, 870, 768, 758, 739, 714, 698, $690 \mathrm{~cm}^{-1}$. HRMS (ESI/Q-TOF) calcd for $\mathrm{C}_{43} \mathrm{H}_{56} \mathrm{~B}_{2} \mathrm{P}_{2} \mathrm{NO}_{2}$ $[\mathrm{M}-\mathrm{H}]^{+}:$702.3972; found 702.3979. Anal. calcd for $\mathrm{C}_{43} \mathrm{H}_{57} \mathrm{~B}_{2} \mathrm{NO}_{2} \mathrm{P}_{2}: \mathrm{C} 73.41, \mathrm{H} 8.17$, N 1.99; found: C 73.72, H 8.16, N 2.09.

4.4.9. $\left(R_{p}\right)-(-)-N-[(1 R, 2 S)-2-(D i p h e n y / p h o s p h i n i t o-b o r a n e)-1-m e t h y l-2-p h e n y l e t h y l], \quad N-$ (methyl amino)phenyl(2-pyridyl)phosphine-borane 12r. The synthesis of 12r was achieved 
using the method A (as described above), by reaction of the complex (-)-10a (1.0 g, 3.5 mmol) previously prepared from 2-bromopyridine $(1.1 \mathrm{~g}, 7 \mathrm{mmol})$ and $s$-BuLi $(1.4 \mathrm{M}$ in cyclohexane, $5.0 \mathrm{~mL}, 7 \mathrm{mmol}$ ). The ring opening product [11r] was then trapped by $\mathrm{Ph}_{2} \mathrm{PCl}$. The purification was performed by column chromatography on silica gel using toluene as eluent. White crystals $\left(1.06 \mathrm{~g}, 54 \%\right.$ yield). $R_{\mathrm{f}}=0.15$ (toluene); $\mathrm{Mp}=178-180{ }^{\circ} \mathrm{C}$; $[\mathrm{a}]_{\mathrm{D}}{ }^{20}=-40.2\left(\mathrm{c} 1.1, \mathrm{CHCl}_{3}\right) .{ }^{1} \mathrm{H} \mathrm{NMR}\left(300 \mathrm{MHz}, \mathrm{CDCl}_{3}\right): \delta 0.20-1.60(\mathrm{~m}, 6 \mathrm{H}), 1.32(\mathrm{~d}, J=$ $6.5 \mathrm{~Hz}, 3 \mathrm{H}), 2.49(\mathrm{~d}, J=7.3 \mathrm{~Hz}, 3 \mathrm{H}), 4.56-4.65(\mathrm{~m}, 1 \mathrm{H}), 5.42(\mathrm{t}, J=9.3 \mathrm{~Hz}, 1 \mathrm{H}), 6.52-6.59$ (m, 2H), 7.00-7.50 (m, 18H), 7.74-7.85 (m, 3H), 7.98-8.00 (m, 1H), 8.73-8.74 (m, 1H). ${ }^{13} \mathrm{C}\left\{{ }^{1} \mathrm{H}\right\} \operatorname{NMR}\left(75.5 \mathrm{MHz}, \mathrm{CDCl}_{3}\right): \delta 16.3,29.8(\mathrm{~d}, J=5.0 \mathrm{~Hz}), 57.5(\mathrm{dd}, J=10.7,8.7 \mathrm{~Hz})$, $83.2(\mathrm{dd}, J=7.3,2.5 \mathrm{~Hz}), 124.9(\mathrm{~d}, J=2.0 \mathrm{~Hz}), 128.0,128.1$ (d, $J=4.2 \mathrm{~Hz}), 128.2,128.3$, $128.6(\mathrm{~d}, J=5.4 \mathrm{~Hz}), 128.6,129.0,129.1(\mathrm{~d}, J=26.5 \mathrm{~Hz}), 129.9(\mathrm{~d}, J=75.8 \mathrm{~Hz}), 130.6(\mathrm{~d}$, $J=2.5 \mathrm{~Hz}), 131.2(\mathrm{~d}, J=11.3 \mathrm{~Hz}), 131.5(\mathrm{~d}, J=2.4 \mathrm{~Hz}), 131.7,131.8(\mathrm{~d}, J=2.5 \mathrm{~Hz})$, $131.9(\mathrm{~d}, J=38.7 \mathrm{~Hz}), 132.7(\mathrm{~d}, J=51.9 \mathrm{~Hz}), 136.1(\mathrm{~d}, J=9.4 \mathrm{~Hz}), 138.2,150.0(\mathrm{~d}, J=$ $12.7 \mathrm{~Hz}$ ). ${ }^{31} \mathrm{P}\left\{{ }^{1} \mathrm{H}\right\} \operatorname{NMR}\left(121.5 \mathrm{MHz}, \mathrm{CDCl}_{3}\right): \delta 72.1$ (br.s), 106.6 (br.s). FTIR (neat): $\mathrm{v}_{\max }$ 3061-2934, 2387, 2345, 1455, 1437, 1421, 1133, 1113, 1062, 1010, 977, 895, 739, 721, $691 \mathrm{~cm}^{-1}$. Anal. calcd for $\mathrm{C}_{33} \mathrm{H}_{38} \mathrm{~B}_{2} \mathrm{~N}_{2} \mathrm{OP}_{2}$ : C 70.50, H 6.81, N 4.98; found: $\mathrm{C} 70.60, \mathrm{H} 6.94$, N 5.20 . 
4.4.10. ( $\left.R_{p}\right)-(-)-N-[(1 R, 2 S)-2-(D i p h e n y l p h o s p h i n i t o-b o r a n e)-1-m e t h y l-2-p h e n y l e t h y l], \quad N-$

methyl amino-2-(2',6'-dimethoxy-1, 1'-biphenyl)phenylphosphine-borane 12s. The synthesis of $12 \mathrm{~s}$ was achieved using the method $\mathrm{A}$ (as described above), by reaction of the complex (-)-10a (1.0 g, $3.5 \mathrm{mmol})$ with the 2',6'-dimethoxy-1,1'-biphenyllithium previously prepared from 2-bromo-2',6'-dimethoxy-1,1'-biphenyl (2.1 g, $7 \mathrm{mmol})$ in THF (3.5 mL) and $t$-BuLi (1.9 $M$ in hexane, $7.4 \mathrm{~mL}, 14 \mathrm{mmol}$ ). The ring opening product [11s] was then trapped by $\mathrm{Ph}_{2} \mathrm{PCl}$. The purification was achieved by column chromatography on silica gel using petroleum ether $/ \mathrm{CH}_{2} \mathrm{Cl}_{2}(2: 1)$ as eluent. White solid $(1.00 \mathrm{~g}, 41 \%$ yield $) . R_{\mathrm{f}}=0.47$ (petroleum ether/ $\left.\mathrm{CH}_{2} \mathrm{Cl}_{2} 2: 1\right) ;[\alpha]_{D}{ }^{20}=-23.3\left(\right.$ c $\left.0.3, \mathrm{CHCl}_{3}\right) .{ }^{1} \mathrm{H}$ NMR $\left(500 \mathrm{MHz}, \mathrm{CDCl}_{3}\right): \delta$ 0.20-1.69 (m, 6H), $1.33(\mathrm{~d}, J=6.1 \mathrm{~Hz}, 3 \mathrm{H}), 2.49(\mathrm{~d}, J=7.6 \mathrm{~Hz}, 3 \mathrm{H}), 3.38(\mathrm{~s}, 3 \mathrm{H}), 3.64$ (s, $3 \mathrm{H}), 4.28-4.34(\mathrm{~m}, 1 \mathrm{H}), 5.37-5.40(\mathrm{~m}, 1 \mathrm{H}), 6.23(\mathrm{~d}, J=8.1 \mathrm{~Hz}, 1 \mathrm{H}), 6.38(\mathrm{~d}, J=8.1 \mathrm{~Hz}$, 1H), 6.90-7.00 (m, 7H), 7.08-7.17 (m, 7H), 7.24-7.32 (m, 4H), 7.38-7.54 (m, 5H), 7.71-7.75 (m, 2H). ${ }^{13} \mathrm{C}\left\{{ }^{1} \mathrm{H}\right\}$ NMR $\left(125.8 \mathrm{MHz}, \mathrm{CDCl}_{3}\right): \delta 14.8,30.4(\mathrm{~d}, J=2.4 \mathrm{~Hz}), 54.8,55.1,57.3(\mathrm{t}$, $J=9.2 \mathrm{~Hz}), 83.8(\mathrm{dd}, J=2.9,6.4 \mathrm{~Hz}), 103.0(\mathrm{~d}, J=17.4 \mathrm{~Hz}), 117.8(\mathrm{~d}, J=3.2 \mathrm{~Hz}), 126.5$ (d, $J=9.2 \mathrm{~Hz}), 127.3(\mathrm{~d}, J=10.3 \mathrm{~Hz}), 127.7,127.8(\mathrm{~d}, J=10.3 \mathrm{~Hz}), 128.2,128.3,128.5$ (d, $J=10.3 \mathrm{~Hz}), 129.3,129.8(\mathrm{~d}, J=2.0 \mathrm{~Hz}), 130.5(\mathrm{~d}, J=59.0 \mathrm{~Hz}), 130.6(\mathrm{~d}, J=1.8 \mathrm{~Hz})$, $131.1(\mathrm{~d}, J=11.6 \mathrm{~Hz}), 131.3(\mathrm{~d}, J=1.8 \mathrm{~Hz}), 131.5,131.6(2 \mathrm{~s}), 131.7,131.8,132.1(\mathrm{~d}, J=$ $28.5 \mathrm{~Hz}), 132.7(\mathrm{~d}, J=36.2 \mathrm{~Hz}), 133.2(\mathrm{~d}, J=8.8 \mathrm{~Hz}), 133.9(\mathrm{~d}, J=7.8 \mathrm{~Hz}), 138.0,140.0$ 
(d, $J=12.0 \mathrm{~Hz}), 157.6,157.8 .{ }^{31} \mathrm{P}\left\{{ }^{1} \mathrm{H}\right\} \mathrm{NMR}\left(202.5 \mathrm{MHz}, \mathrm{CDCl}_{3}\right): \delta+72.1$ (br.s), +106.0106.2 (m). FTIR (neat): $v_{\max } 3075-2820,2380,2369,2337,1583,1476,1436,1242,1164$, 1100, 1086, 998, 963, 870, 795, 738, $718 \mathrm{~cm}^{-1}$. HRMS (ESI/Q-TOF) calcd for $\mathrm{C}_{42} \mathrm{H}_{47} \mathrm{~B}_{2} \mathrm{P}_{2} \mathrm{NO}_{3} \mathrm{Na}[\mathrm{M}+\mathrm{Na}]^{+}:$720.3144; found: 720.3109 .

4.4.11. $\left(R_{\mathrm{p}}\right)-(-)-N-[(1 R, 2 S)-(2-(D i-\alpha-n a p h t y / p h o s p h i n i t o-b o r a n e)-1-m e t h y l-2-p h e n y l e t h y l]$, $N$-methylamino(o-biphenyl)pheny/phosphine-borane 12t. The synthesis of the 12t was achieved using the method $A$ (as described above) by reaction of the complex (-)-10a (1.0 g, $3.5 \mathrm{mmol}$ ) with the 1,1'-biphenyllithium previously prepared from 2-bromo-1,1'-biphenyl (1.3 mL, $7 \mathrm{mmol})$ in THF $(3.5 \mathrm{~mL})$ and $s$-BuLi $(1.4 \mathrm{M}$ in cyclohexane, $5.0 \mathrm{~mL}, 7 \mathrm{mmol})$. The ring opening product [11t] was then trapped by $\alpha-\mathrm{Np}_{2} \mathrm{PCl}$. The purification was achieved by column chromatography on silica gel using petroleum ether/ $\mathrm{CH}_{2} \mathrm{Cl}_{2}(2: 1)$ as eluent. White solid (1.65 g, 64\% yield). $R_{\mathrm{f}}=0.27$ (petroleum ether/ $\mathrm{CH}_{2} \mathrm{Cl}_{2}, 2: 1$ ); $[\mathrm{\alpha}]_{\mathrm{D}}{ }^{20}-93.2$ (c 0.3 , $\left.\mathrm{CHCl}_{3}\right) .{ }^{1} \mathrm{H}$ NMR $\left(500 \mathrm{MHz}, \mathrm{CDCl}_{3}\right): \delta 0.50-1.82(\mathrm{~m}, 6 \mathrm{H}), 1.37(\mathrm{~d}, J=6.9 \mathrm{~Hz}, 3 \mathrm{H}), 2.45(\mathrm{~d}$, $J=6.9 \mathrm{~Hz}, 3 \mathrm{H}), 4.55-4.58(\mathrm{~m}, 1 \mathrm{H}), 5.47(\mathrm{t}, J=8.2 \mathrm{~Hz}, 1 \mathrm{H}), 6.39(\mathrm{t}, J=7.7 \mathrm{~Hz}, 2 \mathrm{H}), 6.53(\mathrm{t}$, $J=7.4 \mathrm{~Hz}, 1 \mathrm{H}), 6.83-6.87(\mathrm{~m}, 6 \mathrm{H}), 6.98-7.08(\mathrm{~m}, 7 \mathrm{H})$, 7.16-7.27 (m, 4H), 7.35-7.38 (m, 2H), 7.41-7.44 (m, 2H), 7.57 (d, J= 8.3 Hz), 7.65-7.75 (m, 3H), $7.80(\mathrm{~d}, J=8.3 \mathrm{~Hz}, 1 \mathrm{H})$, $7.94(\mathrm{~d}, J=8.3 \mathrm{~Hz}, 1 \mathrm{H}), 8.01(\mathrm{~d}, J=7.8 \mathrm{~Hz}, 1 \mathrm{H}), 8.11(\mathrm{dd}, J=15.6,6.4 \mathrm{~Hz}, 1 \mathrm{H}), 8.38$ (ddd, $J=13.0,7.2,1.0 \mathrm{~Hz}, 1 \mathrm{H}) .{ }^{13} \mathrm{C}\left\{{ }^{1} \mathrm{H}\right\} \operatorname{NMR}\left(125.8 \mathrm{MHz}, \mathrm{CDCl}_{3}\right): \delta 15.8(\mathrm{~d}, J=1.6 \mathrm{~Hz})$, 
$29.9(\mathrm{~d}, J=3.1 \mathrm{~Hz}), 57.7(\mathrm{t}, J=10.2 \mathrm{~Hz}), 82.9(\mathrm{dd}, J=4.9,3.0 \mathrm{~Hz}), 124.2(\mathrm{~d}, J=15.8 \mathrm{~Hz})$, $124.9(\mathrm{~d}, J=9.5 \mathrm{~Hz}), 125.7,125.9(\mathrm{~d}, J=6.3 \mathrm{~Hz}), 126.0,126.1,126.4(\mathrm{~d}, J=10.1 \mathrm{~Hz})$, 126.8, 126.9, 127.0, $127.5(\mathrm{~d}, J=10.8 \mathrm{~Hz}), 127.9,128.4(\mathrm{~d}, J=51.2 \mathrm{~Hz}), 128.5,128.8(\mathrm{~d}$, $J=4.2 \mathrm{~Hz}), 128.9,129.3(\mathrm{~d}, J=9.5 \mathrm{~Hz}), 129.8(\mathrm{~d}, J=1.8 \mathrm{~Hz}), 129.9,130.3(\mathrm{~d}, J=1.8 \mathrm{~Hz})$, $130.8(\mathrm{~d}, J=62.4 \mathrm{~Hz}), 131.7(\mathrm{~d}, J=8.9 \mathrm{~Hz}), 131.8,131.9,132.1(\mathrm{~d}, J=11.3 \mathrm{~Hz}), 132.3(\mathrm{~d}$, $J=3.6 \mathrm{~Hz}), 132.7,132.8(\mathrm{~d}, J=2.6 \mathrm{~Hz}), 132.9,133.2-133.3(\mathrm{~m}), 133.6(\mathrm{~d}, J=8.2 \mathrm{~Hz})$, $133.6(\mathrm{~d}, J=8.2 \mathrm{~Hz}), 134.5,134.6,136.4,140.7(\mathrm{~d}, J=2.7 \mathrm{~Hz}), 147.0(\mathrm{~d}, J=9.5 \mathrm{~Hz})$. ${ }^{31} \mathrm{P}\left\{{ }^{1} \mathrm{H}\right\} \operatorname{NMR}\left(202.5 \mathrm{MHz}, \mathrm{CDCl}_{3}\right): \delta+71.3$ (br.s), +106.5 (br.s). FTIR (neat): $\mathrm{v}_{\max } 3057-$ $2807,2393,2375,2345,1579,1475,1437,1242,1163,1099,1086,999,965,871,798$ $\mathrm{cm}^{-1}$. HRMS (ESI/Q-TOF) calcd for $\mathrm{C}_{48} \mathrm{H}_{47} \mathrm{~B}_{2} \mathrm{NOP}_{2} \mathrm{Na}[\mathrm{M}+\mathrm{Na}]^{+}:$760.3211; found: 760.3226 .

4.4.12. (M, $\left.S_{p}\right)-(+)-N-[(1 S, 2 R)-2-(D i p h e n y l p h o s p h i n i t o-b o r a n e)-1-m e t h y l-2-p h e n y l e t h y l]$, N-methylamino-2-(1,1'-binaphtyl)phenylphosphine-borane $12 \mathrm{v}$. The synthesis of $12 \mathrm{v}$ was achieved using the method $B$ (as described above) by reaction of the aminophosphineborane $11 \mathrm{v}(0.30 \mathrm{~g}, 0.56 \mathrm{mmol})$ with $n$-BuLi $(1.6 \mathrm{M}$ in hexane $(0.42 \mathrm{~mL}, 0.67 \mathrm{mmol})$, then with $\mathrm{Ph}_{2} \mathrm{PCl}(0.20 \mathrm{~mL}, 1.12 \mathrm{mmol})$ and borane-dimethyl sulfide $(0.42 \mathrm{~mL}, 4.48 \mathrm{mmol})$. The purification was achieved by chromatography on silica gel using petroleum ether/ $\mathrm{CH}_{2} \mathrm{Cl}_{2}$ $(1: 1)$ as eluent to afford AMPP*-diborane $12 \mathrm{v}$ as a white solid $(0.17 \mathrm{~g}, 41 \%$ yield $) . R_{\mathrm{f}}=0.33$ (petroleum ether/ $\left.\mathrm{CH}_{2} \mathrm{Cl}_{2} 1: 1\right) ;[\alpha]_{D}{ }^{20}=+10.6$ (c $\left.0.8, \mathrm{CHCl}_{3}\right) .{ }^{1} \mathrm{H}$ NMR $\left(500 \mathrm{MHz}, \mathrm{CDCl}_{3}\right): \delta$ 
0.19-1.20 (m, 6H), $1.14(\mathrm{~d}, J=6.4 \mathrm{~Hz}, 3 \mathrm{H}), 2.55(\mathrm{~d}, J=7.4 \mathrm{~Hz}), 4.15-4.22(\mathrm{~m}, 1 \mathrm{H}), 5.36(\mathrm{t}$, $J=9.1 \mathrm{~Hz}, 1 \mathrm{H}), 6.81-6.93(\mathrm{~m}, 9 \mathrm{H}), 7.02-7.09(\mathrm{~m}, 6 \mathrm{H})$, 7.14-7.25 (m, 6H), 7.38-7.41 (m, 1H), 7.43-7.52 (m, 4H), 7.64-7.70 (m, 4H), $7.75(\mathrm{~d}, J=8.2 \mathrm{~Hz}, 1 \mathrm{H}), 7.89-7.92(\mathrm{~m}, 2 \mathrm{H})$. ${ }^{13} \mathrm{C}\left\{{ }^{1} \mathrm{H}\right\} \operatorname{NMR}\left(125.8 \mathrm{MHz}, \mathrm{CDCl}_{3}\right): \delta 14.4,31.2(\mathrm{~d}, J=1.5 \mathrm{~Hz}), 57.6(\mathrm{t}, J=9.0 \mathrm{~Hz}), 83.7$ $(\mathrm{dd}, J=5.5,2.9 \mathrm{~Hz}), 124.6,125.6,125.8,126.6,127.0,127.2(\mathrm{~d}, J=9.6 \mathrm{~Hz}), 127.5(\mathrm{~d}, J=$ $2.9 \mathrm{~Hz}), 127.6,127.7,127.8,127.9(\mathrm{~d}, J=5.0 \mathrm{~Hz}), 128.1,128.2,128.5(\mathrm{~d}, J=2.7 \mathrm{~Hz})$, 128.6, $128.7(d, J=11.2 \mathrm{~Hz}), 129.1,129.8(\mathrm{~d}, J=2.3 \mathrm{~Hz}), 131.0,131.1,131.3(\mathrm{~d}, J=1.8$ $\mathrm{Hz}), 131.4,131.5,131.6(2 \mathrm{~s}), 131.7$ (d, $J=15.6 \mathrm{~Hz}), 132.1$ (d, J = 9.2 Hz), 132.3, 132.6, 133.1, 133.6, 133.9 (d, $J=9.6 \mathrm{~Hz}), 134.0(\mathrm{~d}, J=1.6 \mathrm{~Hz}), 134.6(\mathrm{~d}, J=4.3 \mathrm{~Hz}), 137.9$, $143.7(\mathrm{~d}, J=10.6 \mathrm{~Hz}) ;{ }^{31} \mathrm{P}\left\{{ }^{1} \mathrm{H}\right\} \operatorname{NMR}\left(202.5 \mathrm{MHz}, \mathrm{CDCl}_{3}\right): \delta+73.4$ (br.s), +106.0 (br.s). FTIR (neat): $v_{\max } 3073-2820,2390,2372,2342,1580,1571,1470,1435,1240,1160$, 1151, 1101, 1090, 997, 963, 870, 795, 740, $721 \mathrm{~cm}^{-1}$. HRMS (ESI/Q-TOF) calcd for $\mathrm{C}_{48} \mathrm{H}_{45} \mathrm{BNOP}_{2}\left[\mathrm{M}-\mathrm{BH}_{3}+\mathrm{H}\right]^{+:}$: 724.3097; found 724.3064.

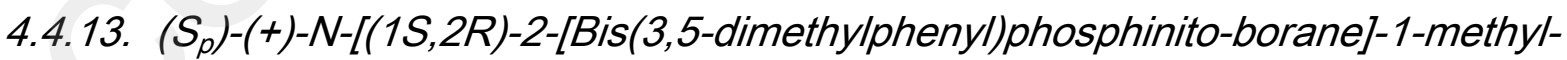

2-phenylethyl], N-methylamino(o-biphenyl)phenylphosphine-borane $12 \mathrm{w}$. This compound was synthesized using the method $A$ (as described above) by reaction of the complex (+)10a $(1.0 \mathrm{~g}, 3.5 \mathrm{mmol})$ prepared from (-)-ephedrine 9, with the o-biphenyllithium reagent previously prepared from 2-bromo-1,1'-biphenyl $(1.2 \mathrm{~mL}, 7 \mathrm{mmol})$ in THF $(3.5 \mathrm{~mL})$ and $s$ - 
BuLi (1.4 $\mathrm{M}$ in cyclohexane, $5 \mathrm{~mL}, 7 \mathrm{mmol}$ ). The ring-opening product [11w] was then trapped with chloro-bis(3,5-dimethylphenyl)phosphine $(3,5-\mathrm{Xyl})_{2} \mathrm{PCl}(1.9 \mathrm{~g}, 7 \mathrm{mmol})$. The purification was achieved by chromatography on silica gel using petroleum ether $/ \mathrm{CH}_{2} \mathrm{Cl}_{2}$ (2:1) as eluent to afford the AMPP*-diborane $12 \mathrm{w}$ as a white sticky solid $(1.02 \mathrm{~g}, 42 \%$ yield); $R_{\mathrm{f}}=0.24$ (petroleum ether $\left./ \mathrm{CH}_{2} \mathrm{Cl}_{2} 2: 1\right) ;[\alpha]_{\mathrm{D}}{ }^{20}=+85.5\left(\mathrm{c} 0.3, \mathrm{CHCl}_{3}\right) \cdot{ }^{1} \mathrm{H}$ NMR $(500$ $\left.\mathrm{MHz}, \mathrm{CDCl}_{3}\right): \delta 0.50-1.52(\mathrm{~m}, 6 \mathrm{H}), 1.26(\mathrm{~d}, J=6.8 \mathrm{~Hz}, 3 \mathrm{H}), 2.05(\mathrm{~s}, 6 \mathrm{H}), 2.37(\mathrm{~s}, 6 \mathrm{H}), 2.44$ (d, $J=6.5 \mathrm{~Hz}, 3 \mathrm{H}), 4.44-4.50(\mathrm{~m}, 1 \mathrm{H}), 5.21(\mathrm{t}, J=9.2 \mathrm{~Hz}, 1 \mathrm{H}), 6.74(\mathrm{~d}, J=9.5 \mathrm{~Hz}, 2 \mathrm{H})$, 6.82-6.85 (m, 3H), 6.90-7.18 (m, 14H), $7.31(\mathrm{~d}, J=5.5 \mathrm{~Hz}, 2 \mathrm{H}), 7.36-7.40(\mathrm{~m}, 1 \mathrm{H}), 7.44-$ $7.52(\mathrm{~m}, 3 \mathrm{H}) .{ }^{13} \mathrm{C}\left\{{ }^{1} \mathrm{H}\right\} \operatorname{NMR}\left(125.8 \mathrm{MHz}, \mathrm{CDCl}_{3}\right): \delta 15.2(\mathrm{~d}, J=1.9 \mathrm{~Hz}), 21.0,21.4,30.0(\mathrm{~d}$, $J=3.5 \mathrm{~Hz}), 57.8(\mathrm{dd}, J=9.9,8.4 \mathrm{~Hz}), 82.8(\mathrm{dd}, J=4.2,3.1 \mathrm{~Hz}), 115.8,120.8,126.9,127.0$ (2s), $127.5,127.6(\mathrm{~d}, J=10.9 \mathrm{~Hz}), 128.1,128.2,128.6(\mathrm{~d}, J=11.4 \mathrm{~Hz}), 129.0(\mathrm{~d}, J=62.0$ $\mathrm{Hz}), 129.1(\mathrm{~d}, J=11.3 \mathrm{~Hz}), 129.9,130.3(\mathrm{~d}, J=1.5 \mathrm{~Hz}), 130.9(\mathrm{~d}, J=62.5 \mathrm{~Hz}), 131.5$, 131.9, 132.0, 132.4, $132.8(\mathrm{~d}, J=8.1 \mathrm{~Hz}), 133.0(\mathrm{~d}, J=2.5 \mathrm{~Hz}), 133.3(\mathrm{~d}, J=9.1 \mathrm{~Hz})$, $133.4(\mathrm{~d}, J=2.0 \mathrm{~Hz}), 137.3(\mathrm{~d}, J=11.3 \mathrm{~Hz}), 138.0(\mathrm{~d}, J=11.9 \mathrm{~Hz}), 138.1,140.8(\mathrm{~d}, J=$ $2.5 \mathrm{~Hz}), 147.0(\mathrm{~d}, J=8.7 \mathrm{~Hz}) .{ }^{31} \mathrm{P}\left\{{ }^{1} \mathrm{H}\right\} \mathrm{NMR}\left(202.5 \mathrm{MHz}, \mathrm{CDCl}_{3}\right): \delta+71.1$ (br.s), +107.4 (br.s). IR (neat): $v_{\max } 3067-2817,2389,2370,2346,1580,1473,1436,1241,1162,1153$, 1099, 998, 965, 870, $797 \mathrm{~cm}^{-1}$. HRMS (ESI/Q-TOF) calcd for $\mathrm{C}_{44} \mathrm{H}_{51} \mathrm{~B}_{2} \mathrm{NOP}_{2}[\mathrm{M}+\mathrm{Na}]^{+}$: 716.3524; found: 716.3534 . 
4.5. Typical procedure for the decomplexation of aminophosphine-phosphinite-

diboranes 12. A solution of aminophosphine-phosphinite-diborane $12(1 \mathrm{mmol})$ and DABCO $(4 \mathrm{mmol})$ in toluene $(3 \mathrm{~mL})$ was heated at $50^{\circ} \mathrm{C}$ with an oil bath and was stirred under argon overnight. After removing the solvent under vacuum, the residue was purified by chromatography on neutral aluminium-oxide using a mixture of petroleum ether/ethyl acetate $(4: 1)$ or toluene as eluent, to afford the free AMPP* 13.

4.5.1. The EPHOS $1^{9 a}$ and the free $o$-anisyl-, ${ }^{9 a} \alpha$-naphtyl-, ${ }^{9 a} \beta$-naphtyl-, ${ }^{9 a} o-b i p h e n y /-,{ }^{9 b}$ ferrocenyl-, ${ }^{9 b}$ t-butyl-, $9 \mathrm{a}$ methyl-, ${ }^{9 a, 10 a}$ cyclohexyl-, ${ }^{\text {gb }}$ o-[(2-methoxyethoxy)methoxy]phenyl-, ${ }^{9 b}$ calixareny/-9c AMPP* ligands $13 \mathrm{a}-\mathrm{c}, 13 \mathrm{f}-\mathrm{h}, 13 \mathrm{j}-\mathrm{I}$ and $13 \mathrm{u}$, respectively, were prepared and characterized according to described procedures.

4.5.2. (S $\left.\left(S_{p}\right)-(-)-N-[(1 R, 2 S)-2-(D i p h e n y / p h o s p h i n i t o)-1-m e t h y l-2-p h e n y l] e t h y l\right], \quad N-m e t h y l$ amino(o-biphenyl)pheny/phosphine 13i. ${ }^{31} \mathrm{P}\left\{{ }^{1} \mathrm{H}\right\}$ NMR $\left(121.5 \mathrm{MHz}, \mathrm{CD}_{2} \mathrm{Cl}_{2}\right): \delta+60.2$, +108.7 .

4.5.3. $\left(R_{\mathrm{p}}\right)-N-[(1 R, 2 S)-2-($ Dipheny/phosphinito)-1-methyl-2-phenylethyl], $N-$ methylamino(2-isopropoxyphenyl)phenylphosphine $13 \mathrm{~m} .{ }^{31} \mathrm{P}\left\{{ }^{1} \mathrm{H}\right\} \quad \mathrm{NMR} \quad(121.5 \mathrm{MHz}$, $\left.\mathrm{CDCl}_{3}\right): \delta+54.7,+111.7$ 
4.5.4.

methylamino(2-benzyloxyphenyl)phenylphosphine 13n. ${ }^{31} \mathrm{P}\left\{{ }^{1} \mathrm{H}\right\} \mathrm{NMR}\left(121.5 \mathrm{MHz}, \mathrm{CDCl}_{3}\right)$ :

$\delta+53.1,+111.1$

4.5.5. ( $\left.R_{p}\right)-N-[(1 R, 2 S)-2-(D i p h e n y l p h o s p h i n i t o)-1-m e t h y l-2-p h e n y l e t h y l], \quad N$-methylamino

(3,5-dimethylphenyl)phenylphosphine 13o. ${ }^{31} \mathrm{P}\left\{{ }^{1} \mathrm{H}\right\} \mathrm{NMR}\left(202.5 \mathrm{MHz}, \mathrm{CDCl}_{3}\right): \delta+61.4$,

+110.6 .

4.5.6.

$\left(R_{p}\right)-N-[(1 R, 2 S)-2-(D i p h e n y l p h o s p h i n i t o)-1-m e t h y l-2-p h e n y l e t h y l]$,

N-

methylamino(3,5-di-t-butylphenyl)phenylphosphine 13p. ${ }^{31} \mathrm{P}\left\{{ }^{1} \mathrm{H}\right\} \mathrm{NMR}\left(121.5 \mathrm{MHz}, \mathrm{CDCl}_{3}\right)$ :

$\delta+68.6,+110.4$

4.5.7. ( $\left.R_{p}\right)-N-[(1 R, 2 S)-2-(D i p h e n y l p h o s p h i n i t o)-1-m e t h y l-2-p h e n y l e t h y l], \quad N$-methylamino

(3,5-di-t-butyl-4-methoxyphenyl)phenylphosphine 13q. ${ }^{31} \mathrm{P}\left\{{ }^{1} \mathrm{H}\right\} \mathrm{NMR}\left(121.5 \mathrm{MHz}, \mathrm{CDCl}_{3}\right): \delta$

$+67.8,+111.5$

4.5.8.

$\left(R_{p}\right)-N-[(1 R, 2 S)-2-(D i p h e n y l p h o s p h i n i t o)-1-m e t h y l-2-p h e n y l e t h y l]$,

$N-$

(methylamino) phenyl(2-pyridyl)phosphine 13r. ${ }^{31} \mathrm{P}\left\{{ }^{1} \mathrm{H}\right\} \mathrm{NMR}\left(202.5 \mathrm{MHz}, \mathrm{CDCl}_{3}\right): \delta+61.3$,

+111.8.

4.5.9. ( $\left(R_{p}\right)-N-[(1 R, 2 S)-2-(D i p h e n y l p h o s p h i n i t o)-1-m e t h y l-2-p h e n y l e t h y l], ~ N-m e t h y l a m i n o-$

2-(2',6'-dimethoxy-1, 1'-biphenyl)phenylphosphine 13s. ${ }^{31} \mathrm{P}\left\{{ }^{1} \mathrm{H}\right\} \mathrm{NMR}\left(121.5 \mathrm{MHz}, \mathrm{CDCl}_{3}\right): \delta$

$+56.5,+110.1$. 
4.5.10.

methylamino (o-biphenyl)pheny/phosphine 13t. ${ }^{31} \mathrm{P}\left\{{ }^{1} \mathrm{H}\right\} \mathrm{NMR}\left(121.5 \mathrm{MHz}, \mathrm{CDCl}_{3}\right): \delta+56.0$,

+97.2 .

4.5.11. (M, $\left.S_{p}\right)-(+)-N-[(1 S, 2 R)-2-(D i p h e n y / p h o s p h i n i t o)-1-m e t h y l-2-p h e n y l e t h y l]$,

$N-$

methylamino-2-(1,1'-binaphtyl)phenylphosphine 13v. ${ }^{31} \mathrm{P}\left\{{ }^{1} \mathrm{H}\right\} \mathrm{NMR}\left(202.5 \mathrm{MHz}, \mathrm{CDCl}_{3}\right): \delta$

$+53.8,+109.9$.

4.5.12. (S $\left.\left(S_{p}\right)-N-[(1 S, 2 R)-2-B i s(3,5-d i m e t h y / p h e n y l) p h o s p h i n i t o]-1-m e t h y l-2-p h e n y l e t h y l\right]$, N-methyl amino(o-biphenyl)pheny/phosphine-borane $13 \mathrm{w} .{ }^{31} \mathrm{P}\left\{{ }^{1} \mathrm{H}\right\} \mathrm{NMR}(121.5 \mathrm{MHz}$, $\left.\mathrm{CDCl}_{3}\right): \delta+56.0,+114.0$

4.6. AMPP*-diborane $\left(1 S_{\mathrm{p}}, 2 R_{\mathrm{p}}\right)-15 \mathrm{e}$ bearing P-chirogenic aminophosphine and phosphinite moieties. $\left(S_{p}\right)-(+)-N-\left\{(1 S, 2 R)-2-\left[\left(R_{p}\right)-o-\right.\right.$ Anisy/pheny/phosphinito-borane]-1methyl-2-phenylethy/\}, N-methylamino-o-anisy/pheny/phosphine-borane $15 e$.

This compound was synthesized from (-)-ephedrine 9 according to the described procedure. ${ }^{9 a}$ Suitable colorless crystals for $\mathrm{X}$-ray structure were obtained by slow evaporation of $\mathrm{CH}_{2} \mathrm{Cl}_{2}$. Crystallographic data and structure of $\left(1 S_{\mathrm{p}}, 2 R_{\mathrm{p}}\right)-15 \mathrm{e}$ were reported in SI.

4.7. Synthesis of AMPP*-diborane 21a-i with a P-chirogenic phosphinite moieties. 
4.7.1. Typical procedure. ${ }^{12}$ To a solution of the aminophosphine-borane $11(1 \mathrm{mmol})$ in toluene $(3 \mathrm{~mL})$ was added $0.6 \mathrm{mmol}\left(2.0 \mathrm{mmol}\right.$ for 11 with $\mathrm{R}^{1}=$ alkyl $)$ of $\mathrm{DABCO}$. The solution was heated at $50^{\circ} \mathrm{C}$ with an oil bath and was stirred overnight. Chlorodiphenylphosphine $(2 \mathrm{mmol})$ and triethylamine $(5 \mathrm{mmol})$ were added at room temperature. The solution was stirred for $4 \mathrm{~h}$ before addition of $\mathrm{BH}_{3}$. DMS $(8 \mathrm{mmol})$ at $0{ }^{\circ} \mathrm{C}$ and the mixture was again stirred for $4 \mathrm{~h}$. After hydrolysis, the aqueous phase was extracted with dichloromethane and the organic phase was washed with saturated $\mathrm{NaCl}$ solution, dried over $\mathrm{MgSO}_{4}$ and evaporated. The residue was purified by chromatography on silica gel with toluene as eluent to afford the $\operatorname{AMPP}{ }^{*}\left(\mathrm{BH}_{3}\right)_{2} 21$ which was recrystallized in a mixture of hexane/ $\mathrm{CH}_{2} \mathrm{Cl}_{2}$.

4.7.2. $\left(S_{p}\right)-(+)-N-[(1 S, 2 R)-2-(o-A n i s y / p h e n y / p h o s p h i n i t o-b o r a n e)-1-m e t h y l-2-p h e n y l e t h y l]$, $N$-methylaminodiphenylphosphine-borane 21a. This compound was synthesized from $\left(S_{p}\right)$ (+)-N-[(1S,2R)-2-hydroxy-1-methyl-2-phenylethyl], N-methylamino(o-anisyl)phenyl phosphine-borane 11a previously prepared from (-)-ephedrine $9 .{ }^{11 \mathrm{~b}} \mathrm{X}$-ray quality crystals were grown by slow evaporation of $\mathrm{CH}_{2} \mathrm{Cl}_{2}$; The structure and the data were reported in the SI. White crystalline needles $\left(0.38 \mathrm{~g}, 65 \%\right.$ yield); $R_{\mathrm{f}}=0.60$ (toluene); $\mathrm{Mp}=155^{\circ} \mathrm{C} .[\alpha]_{\mathrm{D}}{ }^{20}=$ $+68.8\left(\mathrm{c} 0.6, \mathrm{CHCl}_{3}\right) .{ }^{1} \mathrm{H} \mathrm{NMR}\left(500 \mathrm{MHz}, \mathrm{CDCl}_{3}\right): \delta 0.34-1.45(\mathrm{~m}, 6 \mathrm{H}), 1.26(\mathrm{~d}, J=6.6 \mathrm{~Hz}$, 3H), $2.21(\mathrm{~d}, J=7.6 \mathrm{~Hz}, 3 \mathrm{H}), 3.47(\mathrm{~s}, 3 \mathrm{H}), 4.47-4.57(\mathrm{~m}, 1 \mathrm{H}), 5.33(\mathrm{t}, J=9.4 \mathrm{~Hz}, 1 \mathrm{H}), 6.51-$ 
$6.58(\mathrm{~m}, 2 \mathrm{H}), 6.77(\mathrm{dd}, J=8.2,4.6 \mathrm{~Hz}, 1 \mathrm{H}), 6.95-7.09(\mathrm{~m}, 8 \mathrm{H}), 7.10-7.15(\mathrm{~m}, 1 \mathrm{H}), 7.16-$ $7.34(\mathrm{~m}, 7 \mathrm{H}), 7.35-7.50(\mathrm{~m}, 4 \mathrm{H}), 7.80(\mathrm{ddd}, J=11.9,7.0,1.7 \mathrm{~Hz}, 1 \mathrm{H}) .{ }^{13} \mathrm{C}\left\{{ }^{1} \mathrm{H}\right\} \mathrm{NMR}:(125.8$ $\left.\mathrm{MHz}, \mathrm{CDCl}_{3}\right): \delta 16.0,29.4(\mathrm{~d}, J=4.5 \mathrm{~Hz}), 55.5,57.6(\mathrm{dd}, J=11.1,8.6 \mathrm{~Hz}), 82.4(\mathrm{dd}, J=$ 8.9, $2.5 \mathrm{~Hz}), 111.8(\mathrm{~d}, J=5.2 \mathrm{~Hz}), 120.2(\mathrm{~d}, J=70.2 \mathrm{~Hz}), 120.8(\mathrm{~d}, J=10.5 \mathrm{~Hz}), 127.4(\mathrm{~d}$, $J=10.9 \mathrm{~Hz}), 128.0(\mathrm{~d}, J=10.9 \mathrm{~Hz}), 128.1,128.3(\mathrm{~d}, J=8.4 \mathrm{~Hz}), 128.4,128.7,129.7(\mathrm{~d}, J$ $=71.7 \mathrm{~Hz}), 130.3(\mathrm{~d}, J=2.4 \mathrm{~Hz}), 130.6(\mathrm{~d}, J=2.2 \mathrm{~Hz}), 130.7(\mathrm{~d}, J=57.3 \mathrm{~Hz}), 131.0,131.7$ (d, $J=10.5 \mathrm{~Hz}), 132.5(\mathrm{~d}, J=10.2 \mathrm{~Hz}), 132.6(\mathrm{~d}, J=62.4 \mathrm{~Hz}), 133.3(\mathrm{~d}, J=9.3 \mathrm{~Hz}), 133.9$ $(\mathrm{d}, J=2.0 \mathrm{~Hz}), 138.4,160.9(\mathrm{~d}, J=4.4 \mathrm{~Hz}) \cdot{ }^{31} \mathrm{P}\left\{{ }^{1} \mathrm{H}\right\} \operatorname{NMR}\left(202.5 \mathrm{MHz}, \mathrm{CDCl}_{3}\right): \delta+71.1$ (br.s), +105.3 (br.s). HRMS (ESI/Q-TOF) calcd for $\mathrm{C}_{35} \mathrm{H}_{41} \mathrm{~B}_{2} \mathrm{NO}_{2} \mathrm{P}_{2} \mathrm{Na}[\mathrm{M}+\mathrm{Na}]^{+:}$614.27026; found 614.26804. Anal. calcd for $\mathrm{C}_{35} \mathrm{H}_{41} \mathrm{~B}_{2} \mathrm{NO}_{2} \mathrm{P}_{2}$ : C 71.10, H 6.99, N 2.37; found: C 70.76, H 7.02, N 2.46.

4.7.3. $\left(R_{p}\right)-(+)-N-[(1 R, 2 S)-2-(0-A n i s y l p h e n y l p h o s p h i n i t o-b o r a n e)-1-m e t h y l-2-$

phenylethyl], N-methylaminodiphenylphosphine-borane 21a. This enantiomer was synthesized from $\left(R_{p}\right)-(+)-N-[(1 R, 2 S)-2-h y d r o x y-1-m e t h y l-2-p h e n y l e t h y l], N$-methylamino(oanisyl)phenyl phosphine-borane 11a previously prepared from (+)-ephedrine $9 .{ }^{11 b}(0.40 \mathrm{~g}$, $68 \%$ yield). ${ }^{31} \mathrm{P}\left\{{ }^{1} \mathrm{H}\right\} \operatorname{NMR}\left(202.5 \mathrm{MHz}, \mathrm{CDCl}_{3}\right): \delta+71.3$ (br.s), +105.1 (br.s).

4.7.4. $\left(S_{p}\right)-(+)-N-[(1 S, 2 R)-2-(\alpha-N a p h t y l p h e n y l p h o s p h i n i t o-b o r a n e)-1-m e t h y l-2-$ phenylethyl], N-methylaminodiphenylphosphine-borane 21b. This compound was 
synthesized from $\left(S_{p}\right)-(+)-N-[(1 S, 2 R)-2-h y d r o x y-1-m e t h y l-2-p h e n y l e t h y l], N$-methylamino( $\alpha$ naphtyl)pheny/phosphine-borane 11c previously prepared from (-)-ephedrine 9. ${ }^{11 b, 29}$ X-ray quality crystals were grown by slow evaporation of $\mathrm{CH}_{2} \mathrm{Cl}_{2}$. The structure and the data were reported in the SI. Colorless crystals $\left(0.37 \mathrm{~g}, 61 \%\right.$ yield); $R_{\mathrm{f}}=0.60$ (toluene); $\mathrm{Mp}=$ $198{ }^{\circ} \mathrm{C} .[\alpha]_{D}{ }^{20}=+48.9\left(\mathrm{c} 0.5, \mathrm{CHCl}_{3}\right) .{ }^{1} \mathrm{H}$ NMR $\left(500 \mathrm{MHz}, \mathrm{CDCl}_{3}\right): \delta 0.38-1.61(\mathrm{~m}, 6 \mathrm{H}), 1.02$ (d, $J=6.6 \mathrm{~Hz}, 3 \mathrm{H}), 2.19(\mathrm{~d}, J=7.6 \mathrm{~Hz}, 3 \mathrm{H}), 4.42-4.54(\mathrm{~m}, 1 \mathrm{H}), 5.51(\mathrm{t}, J=9.7 \mathrm{~Hz}, 1 \mathrm{H})$, $6.56(\mathrm{dd}, J=11.3,7.8 \mathrm{~Hz}, 2 \mathrm{H}), 6.93-7.02(\mathrm{~m}, 4 \mathrm{H}), 7.03-7.21(\mathrm{~m}, 8 \mathrm{H}), 7.22-7.45(\mathrm{~m}, 8 \mathrm{H})$, 7.49-7.54 (m, 1H), $7.77(\mathrm{~d}, J=8.2 \mathrm{~Hz}, 1 \mathrm{H}), 7.94(\mathrm{~d}, J=8.5 \mathrm{~Hz}, 2 \mathrm{H}), 8.31$ (ddd, $J=14.8$, 7.1, $0.7 \mathrm{~Hz}, 1 \mathrm{H}) .{ }^{13} \mathrm{C}\left\{{ }^{1} \mathrm{H}\right\} \operatorname{NMR}\left(125.8 \mathrm{MHz}, \mathrm{CDCl}_{3}\right): \delta 16.0,29.4(\mathrm{~d}, J=4.5 \mathrm{~Hz}), 57.5(\mathrm{dd}, J$ = 11.2, 7.7 Hz), 83.6 (dd, $J=8.9,3.0 \mathrm{~Hz}), 124.7(\mathrm{~d}, J=13.5 \mathrm{~Hz}), 126.3,126.8(\mathrm{~d}, J=5.0$ $\mathrm{Hz}), 127.1,127.7(\mathrm{~d}, J=63.7 \mathrm{~Hz}), 128.0(\mathrm{~d}, J=5.7 \mathrm{~Hz}), 128.1(\mathrm{~d}, J=6.1 \mathrm{~Hz}), 128.3$, 128.4, 128.6, 128.9, 129.0, $129.7(\mathrm{~d}, J=71.6 \mathrm{~Hz}), 130.4(\mathrm{~d}, J=2.0 \mathrm{~Hz}), 130.9,130.9(\mathrm{~d}, J$ $=11.8 \mathrm{~Hz}), 131.1(\mathrm{~d}, J=1.7 \mathrm{~Hz}), 131.7(\mathrm{~d}, J=10.3 \mathrm{~Hz}), 132.3(\mathrm{~d}, J=6.4 \mathrm{~Hz}), 132.5(\mathrm{~d}, J=$ $10.2 \mathrm{~Hz}), 133.0(\mathrm{~d}, J=63.3 \mathrm{~Hz}), 133.5(\mathrm{~d}, J=2.4 \mathrm{~Hz}), 133.8(\mathrm{~d}, J=7.6 \mathrm{~Hz}), 133.9,134.0$, 138.5. ${ }^{31} \mathrm{P}\left\{{ }^{1} \mathrm{H}\right\} \mathrm{NMR}\left(202.5 \mathrm{MHz}, \mathrm{CDCl}_{3}\right): \delta+71.3$ (br.s), +110.0 (br.s). HRMS (ESI/Q-TOF) calcd for $\mathrm{C}_{38} \mathrm{H}_{41} \mathrm{~B}_{2} \mathrm{NOP}_{2} \mathrm{Na}[\mathrm{M}+\mathrm{Na}]^{+}$: 634.27472; found: 634.27398. HRMS (ESI/Q-TOF) calcd for $\mathrm{C}_{38} \mathrm{H}_{42} \mathrm{~B}_{2} \mathrm{NOP}_{2}[\mathrm{M}+\mathrm{H}]^{+}$: 612.29278; found: 612.29213 . 
phenylethyl], N-methylaminodiphenylphosphine-borane 21b. This enantiomer was synthesized from $\left(R_{p}\right)-(+)-N-[(1 R, 2 S)-2-h y d r o x y-1-m e t h y l-2-p h e n y l e t h y l], N$-methylamino $(\alpha-$ naphtyl)phenylphosphine-borane 11c previously prepared from (+)-ephedrine $9 .^{11 b, 29}(0.39$ g, 63\% yield). ${ }^{31} \mathrm{P}\left\{{ }^{1} \mathrm{H}\right\}$ NMR (202.5 MHz, $\left.\mathrm{CDCl}_{3}\right): \delta+71.5$ (br.s), +110.2 (br.s).

4.7.6. $\left(R_{p}\right)-(-)-N-[(1 R, 2 S)-2-(\beta-N a p h t y l p h e n y / p h o s p h i n i t o-b o r a n e)-1-m e t h y l-2-$

phenylethyl], N-methylaminodiphenylphosphine-borane 21c. This compound was synthesized from $\left(R_{p}\right)-(-)-N-[(1 R, 2 S)-2-h y d r o x y-1-m e t h y l-2-p h e n y l e t h y l], N$-methylamino( $\beta$ naphtyl)phenylphosphine-borane 11d previously prepared from (+)-ephedrine $9 .{ }^{11 \mathrm{~b}, 29 \mathrm{~b}} \mathrm{X}$ ray quality crystals were grown by slow evaporation of cyclohexane. The structure and the data were reported in the SI. Colorless crystals $\left(0.49 \mathrm{~g}, 81 \%\right.$ yield); $R_{\mathrm{f}}=0.60$ (toluene); Mp $=151^{\circ} \mathrm{C} .[\alpha]_{D^{20}}=-66.3\left(\mathrm{c} 0.6, \mathrm{CHCl}_{3}\right) .{ }^{1} \mathrm{H}$ NMR $\left(300 \mathrm{MHz}, \mathrm{CDCl}_{3}\right): \delta 0.38-1.81(\mathrm{~m}, 6 \mathrm{H})$, $1.35(\mathrm{~d}, J=6.5 \mathrm{~Hz}, 3 \mathrm{H}), 2.33(\mathrm{~d}, J=7.5 \mathrm{~Hz}, 3 \mathrm{H}), 4.58-4.74(\mathrm{~m}, 1 \mathrm{H}), 5.46(\mathrm{t}, J=9.4 \mathrm{~Hz}$, 1H), 6.59-6.71 (m, 2H), 7.05-7.23 (m, 6H), 7.26-7.66 (m, 14H), 7.68-7.77 (m, 1H), 7.86$8.00(\mathrm{~m}, 3 \mathrm{H}), 8.33(\mathrm{~d}, J=12.7 \mathrm{~Hz}, 1 \mathrm{H}) .{ }^{13} \mathrm{C}\left\{{ }^{1} \mathrm{H}\right\} \operatorname{NMR}\left(75.5 \mathrm{MHz}, \mathrm{CDCl}_{3}\right): \delta 16.0,29.4(\mathrm{~d}, J$ $=4.5 \mathrm{~Hz}), 57.5(\mathrm{dd}, J=11.2,8.6 \mathrm{~Hz}), 83.6(\mathrm{dd}, J=8.8,3.0 \mathrm{~Hz}), 126.1(\mathrm{~d}, J=10.3 \mathrm{~Hz})$, 126.9, $127.9(\mathrm{~d}, J=3.5 \mathrm{~Hz}), 128.0(\mathrm{~d}, J=2.8 \mathrm{~Hz}), 128.2(\mathrm{~d}, J=2.9 \mathrm{~Hz}), 128.3,128.4(\mathrm{~d}, J$ $=10.0 \mathrm{~Hz}), 128.4,128.6,128.8,129.0,129.2,130.2(\mathrm{~d}, J=7.5 \mathrm{~Hz}), 130.4(\mathrm{~d}, J=2.2 \mathrm{~Hz})$, 
131.0, $131.2(\mathrm{~d}, J=2.1 \mathrm{~Hz}), 131.4(\mathrm{~d}, J=2.1 \mathrm{~Hz}), 131.5,131.6(\mathrm{~d}, J=1.2 \mathrm{~Hz}), 131.8$, 132.4, $132.5(\mathrm{~d}, J=10.3 \mathrm{~Hz}), 132.6(\mathrm{~d}, J=18.8 \mathrm{~Hz}), 132.8(\mathrm{~d}, J=12.6 \mathrm{~Hz}), 134.6(\mathrm{~d}, J=$ 2.3 Hz), 138.1. ${ }^{31} \mathrm{P}\left\{{ }^{1} \mathrm{H}\right\}$ NMR (121.5 MHz, $\left.\mathrm{CDCl}_{3}\right): \delta+71.1$ (br.s), +107.2 (br.s). HRMS (ESI/Q-TOF) calcd for $\mathrm{C}_{38} \mathrm{H}_{41} \mathrm{~B}_{2} \mathrm{NOP}_{2} \mathrm{Na}[\mathrm{M}+\mathrm{Na}]^{+}:$: 634.27472; found: 634.27319.

\subsection{7. (R $\left(R_{p}\right)-(-)-N-[(1 R, 2 S)-2-(P h e n y l-o-t o l y l p h o s p h i n i t o-b o r a n e)-1-m e t h y l-2-p h e n y l e t h y l]$,}

$N$-methylaminodiphenylphosphine-borane $21 \mathrm{~d}$. This compound was synthesized from $\left(R_{p}\right)$ (-)-N-[(1R,2S)-2-hydroxy-1-methyl-2-phenylethyl], N-methylamino(phenyl-o-

tolyl)phosphine-borane 11d previously prepared (+)-ephedrine $9 .{ }^{30,31}$ X-ray quality crystals were grown by slow evaporation of hexane. The structure and the data were reported in the SI. Colorless crystals $\left(0.37 \mathrm{~g}, 65 \%\right.$ yield); $R_{\mathrm{f}}=0.60$ (toluene); $\mathrm{Mp}=190{ }^{\circ} \mathrm{C} .[\alpha]_{\mathrm{D}}{ }^{20}=-$ 59.3 (c 0.5, $\left.\mathrm{CHCl}_{3}\right)$. ${ }^{1} \mathrm{H} \operatorname{NMR}\left(300 \mathrm{MHz}^{\mathrm{C}} \mathrm{CDCl}_{3}\right): \delta 0.25-1.66(\mathrm{~m}, 6 \mathrm{H}), 1.17(\mathrm{~d}, J=6.5 \mathrm{~Hz}$, 3H), $2.07(\mathrm{~s}, 3 \mathrm{H}), 2.23(\mathrm{~d}, J=7.6 \mathrm{~Hz}, 3 \mathrm{H}), 4.42-4.62(\mathrm{~m}, 1 \mathrm{H}), 5.43(\mathrm{t}, J=9.6 \mathrm{~Hz}, 1 \mathrm{H}), 6.50-$ $6.60(\mathrm{~m}, 2 \mathrm{H}), 6.95-7.24(\mathrm{~m}, 12 \mathrm{H}), 7.27-7.51(\mathrm{~m}, 9 \mathrm{H}), 8.04$ (ddd, J=12.5, 7.4, $1.4 \mathrm{~Hz}, 1 \mathrm{H})$. ${ }^{13} \mathrm{C}\left\{{ }^{1} \mathrm{H}\right\}$ NMR $\left(75.5 \mathrm{MHz}, \mathrm{CDCl}_{3}\right): \delta 16.2,21.6(\mathrm{~d}, J=4.3 \mathrm{~Hz}), 29.4(\mathrm{~d}, J=4.6 \mathrm{~Hz}), 57.4$ (dd, $J=11.2,7.7 \mathrm{~Hz}), 83.1(\mathrm{dd}, J=9.3,2.8 \mathrm{~Hz}), 125.7(\mathrm{~d}, J=11.6 \mathrm{~Hz}), 127.9(\mathrm{~d}, J=3.1$ $\mathrm{Hz}), 128.1(\mathrm{~d}, J=3.0 \mathrm{~Hz}), 128.3,128.4(\mathrm{~d}, J=2.8 \mathrm{~Hz}), 128.7,129.2(\mathrm{~d}, J=18.6 \mathrm{~Hz}), 130.2$ $(\mathrm{d}, J=6.8 \mathrm{~Hz}), 130.3(\mathrm{~d}, J=2.4 \mathrm{~Hz}), 130.6(\mathrm{~d}, J=51.9 \mathrm{~Hz}), 130.9,131.0,131.2(\mathrm{~d}, J=2.1$ $\mathrm{Hz}), 131.7,131.7(\mathrm{~d}, J=10.2 \mathrm{~Hz}), 132.1(\mathrm{~d}, J=2.3 \mathrm{~Hz}), 132.6(\mathrm{~d}, J=61.6 \mathrm{~Hz}), 132.5(\mathrm{~d}, J$ 
$=10.4 \mathrm{~Hz}), 132.9(\mathrm{~d}, J=14.2 \mathrm{~Hz}), 138.4,141.5(\mathrm{~d}, J=8.8 \mathrm{~Hz}) .{ }^{31} \mathrm{P}\left\{{ }^{1} \mathrm{H}\right\} \mathrm{NMR}:(121.5 \mathrm{MHz}$, $\left.\mathrm{CDCl}_{3}\right): \delta+70.9$ (br.s), +109.3 (br.s). HRMS (ESI/Q-TOF) calcd for $\mathrm{C}_{35} \mathrm{H}_{41} \mathrm{~B}_{2} \mathrm{NOP} \mathrm{Na}_{2} \mathrm{Na}$ $[\mathrm{M}+\mathrm{Na}]^{+}:$598.27472; found: 598.27261 . Anal. calcd for $\mathrm{C}_{35} \mathrm{H}_{41} \mathrm{~B}_{2} \mathrm{NOP}_{2}: \mathrm{C}$ 73.07, H 7.18, N 2.43; found: C 72.70, H 7.28, N 2.62.

4.7.8. $\left(S_{p}\right)-N-[(1 S, 2 R)-2-(P h e n y l-o-t o l y / p h o s p h i n i t o-b o r a n e)-1-m e t h y l-2-p h e n y l e t h y l], \quad N-$ methyl aminodiphenylphosphine-borane 21d. This compound was synthesized as described for $\left(R_{p}\right)-21 \mathrm{~d}(\S 4.7 .7$.) starting from (-)-ephedrine 9 . X-ray quality crystals were grown by slow evaporation of hexane. The structure and the data were reported in the SI.

4.7.9. ( $\left(R_{p}\right)-(-)-N-[(1 R, 2 S)-2-($ Phenyl-p-tolylphosphinito-borane)-1-methyl-2-phenylethyl], $N$-methylaminodiphenylphosphine-borane $21 \mathrm{e}$. This compound was synthesized from $\left(R_{p}\right)$ (-)-N-[(1R,2S)-2-hydroxy-1-methyl-2-phenylethyl], N-methylamino(phenyl-ptolyl)phosphine-borane $11 \mathrm{e}$ previously prepared from (+)-ephedrine $9 .{ }^{31} \mathrm{X}$-ray quality crystals were grown by slow evaporation of diethyl ether. The structure and the data were reported in the SI. Colorless crystals $\left(0.39 \mathrm{~g}, 67 \%\right.$ yield); $R_{\mathrm{f}}=0.60$ (toluene); $\mathrm{Mp}=156{ }^{\circ} \mathrm{C}$. $[\mathrm{a}]_{\mathrm{D}}{ }^{20}=-71.6\left(\mathrm{c} 0.5, \mathrm{CHCl}_{3}\right) .{ }^{1} \mathrm{H} \mathrm{NMR}\left(500 \mathrm{MHz}, \mathrm{CDCl}_{3}\right): \delta 0.30-1.68(\mathrm{~m}, 6 \mathrm{H}), 1.25(\mathrm{~d}, J=$ $6.5 \mathrm{~Hz}, 3 \mathrm{H}), 2.22(\mathrm{~d}, J=7.6 \mathrm{~Hz}, 3 \mathrm{H}), 2.32(\mathrm{~s}, 3 \mathrm{H}), 4.46-4.55(\mathrm{~m}, 1 \mathrm{H}), 5.30(\mathrm{t}, J=9.4 \mathrm{~Hz}$, 1H), 6.52-6.58 (m, 2H,), 6.97-7.11 (m, 7H), 7.15-7.24 (m, 6H), 7.28-7.35 (m, 4H), 7.37-7.42 (m, 1H), 7.43-7.49 (m, 2H), 7.51-7.56 (m, 2H). ${ }^{13} \mathrm{C}\left\{{ }^{1} \mathrm{H}\right\} \mathrm{NMR}\left(125.8 \mathrm{MHz}, \mathrm{CDCl}_{3}\right): \delta 16.2$ 


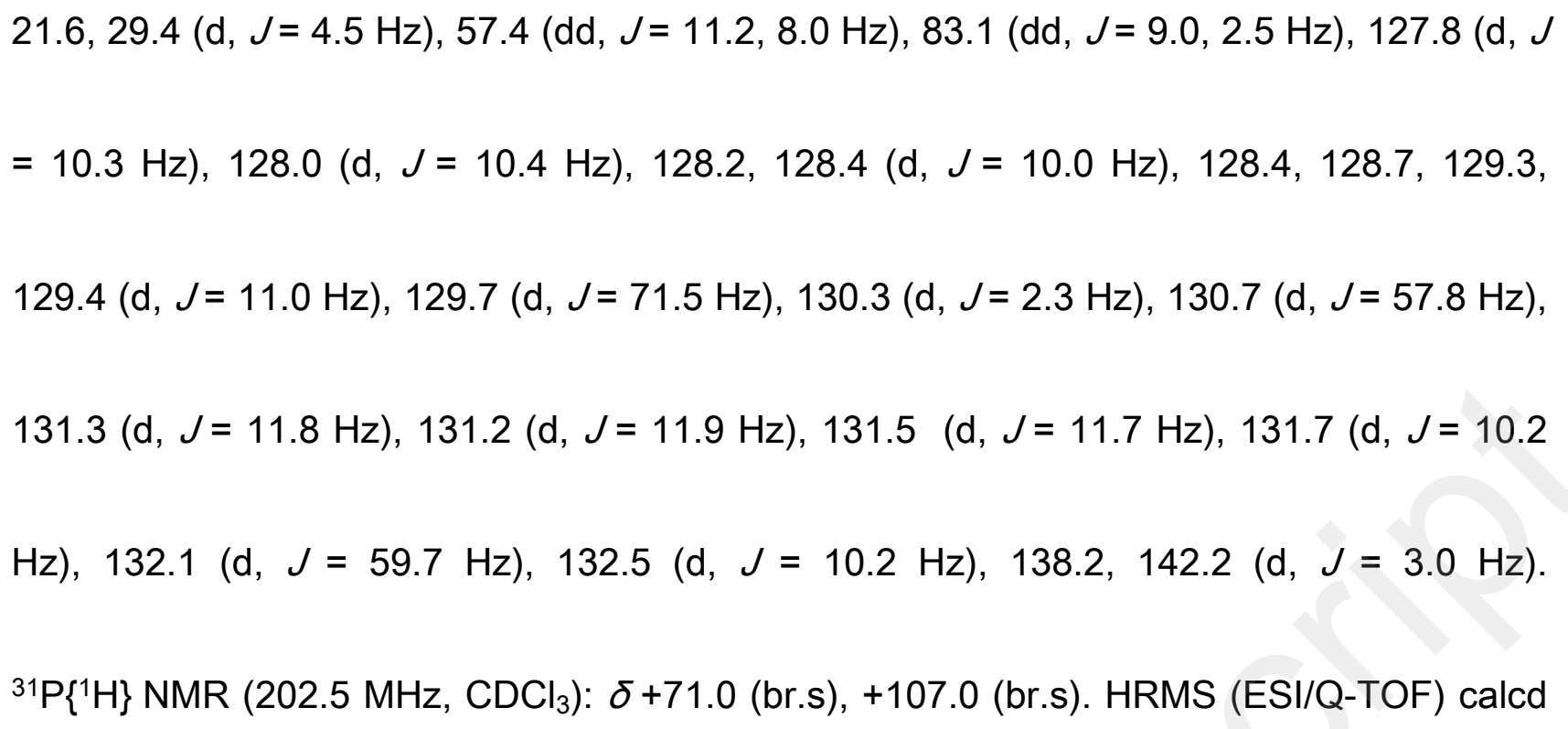
for $\mathrm{C}_{35} \mathrm{H}_{41} \mathrm{~B}_{2} \mathrm{NOP}{ }_{2} \mathrm{Na} \quad[\mathrm{M}+\mathrm{Na}]^{+}:$598.27417; found: 598.27340. Anal. calcd for $\mathrm{C}_{35} \mathrm{H}_{41} \mathrm{~B}_{2} \mathrm{NOP}_{2}$ : C 73.07, H 7.18, N 2.43; found: C 72.70, H 7.28, N 2.52.

4.7.10. (R $\quad$ (R)-(-)-N-[(1R,2S)-2-(Phenyl-o-biphenylphosphinito-borane)-1-methyl-2-

phenylethyl], N-methylamino-diphenylphosphine-borane 21f. This compound was synthesized from $\quad\left(R_{p}\right)-(-)-N-[(1 R, 2 S)-2-h y d r o x y-1-m e t h y l-2-p h e n y l e t h y l], \quad N-$ methylamino(phenyl-o-biphenyl)phosphine-borane $11 \mathrm{f}$ previously prepared from (+)ephedrine 9 . $^{11 b, 29,30}$ X-ray quality crystals were grown by slow evaporation of $\mathrm{CH}_{2} \mathrm{Cl}_{2}$. The structure and the data were reported in the SI. White solid; $(0.43 \mathrm{~g}, 67 \%$ yield $) ; R_{\mathrm{f}}=0.57$ (petroleum ether/dichloromethane 1:1); $\mathrm{Mp}=217^{\circ} \mathrm{C} .[\mathrm{\alpha}]_{\mathrm{D}}{ }^{20}=-5.9\left(\mathrm{c} 0.4, \mathrm{CHCl}_{3}\right) .{ }^{1} \mathrm{H}^{\mathrm{NMR}}$ : (500 MHz, $\left.\mathrm{CD}_{2} \mathrm{Cl}_{2}\right): \delta 0.48-1.52(\mathrm{~m}, 6 \mathrm{H}), 1.29(\mathrm{~d}, J=5.7 \mathrm{~Hz}, 3 \mathrm{H}), 2.29(\mathrm{~d}, J=7.6 \mathrm{~Hz}, 3 \mathrm{H})$, 4.51-4.54 (m, 1H), $5.54(\mathrm{t}, J=9.9 \mathrm{~Hz}, 1 \mathrm{H}), 6.60-6.64(\mathrm{~m}, 2 \mathrm{H}), 6.69-6.73(\mathrm{~m}, 2 \mathrm{H}), 6.84-6.86$ $(\mathrm{m}, 2 \mathrm{H}), 6.90-6.94(\mathrm{~m}, 2 \mathrm{H}), 7.11-7.17(\mathrm{~m}, 5 \mathrm{H}), 7.22-7.35(\mathrm{~m}, 8 \mathrm{H}), 7.44-7.63(\mathrm{~m}, 7 \mathrm{H}), 8.33$ 
$(\mathrm{dd}, J=13.1,7.2 \mathrm{~Hz}, 1 \mathrm{H}) .{ }^{13} \mathrm{C}\left\{{ }^{1} \mathrm{H}\right\} \operatorname{NMR}\left(125.8 \mathrm{MHz}, \mathrm{CD}_{2} \mathrm{Cl}_{2}\right): \delta(\mathrm{ppm}) 16.0,29.2(\mathrm{~d}, J=$ 4.5 Hz), 57.3 (dd, $J=10.9,7.0 \mathrm{~Hz}$ ), 83.6 (dd, $J=9.5,3.3 \mathrm{~Hz}), 127.0(\mathrm{~d}, J=12.5 \mathrm{~Hz}$ ), 127.1 (2s), $127.4(\mathrm{~d}, J=11.1 \mathrm{~Hz}), 128.0(\mathrm{~d}, J=10.2 \mathrm{~Hz}), 128.3,128.4(\mathrm{~d}, J=9.9 \mathrm{~Hz}), 128.5$, 128.7, 129.5, 129.8, 130.1 (d, $J=12.5 \mathrm{~Hz}), 130.2(\mathrm{~d}, J=3.7 \mathrm{~Hz}), 130.3(\mathrm{~d}, J=2.1 \mathrm{~Hz})$, $130.5(\mathrm{~d}, J=24.5 \mathrm{~Hz}), 131.0(\mathrm{~d}, J=32.0 \mathrm{~Hz}), 131.1(\mathrm{~d}, J=2.1 \mathrm{~Hz}), 131.6(\mathrm{~d}, J=10.3 \mathrm{~Hz})$, $131.7(\mathrm{~d}, J=2.2 \mathrm{~Hz}), 131.9(\mathrm{~d}, J=7.7 \mathrm{~Hz}), 132.5(\mathrm{~d}, J=10.3 \mathrm{~Hz}), 133.3(\mathrm{~d}, J=63.5 \mathrm{~Hz})$, $133.5(\mathrm{~d}, J=18.0 \mathrm{~Hz}), 138.5,140.3(\mathrm{~d}, J=3.0 \mathrm{~Hz}), 146.7(\mathrm{~d}, J=5.3 \mathrm{~Hz}) .{ }^{31} \mathrm{P}\left\{{ }^{1} \mathrm{H}\right\} \mathrm{NMR}$ (202.5 MHz, $\mathrm{CD}_{2} \mathrm{Cl}_{2}$ ): $\delta+71.1$ (br.s), +110.6 (br.s). IR (neat): $\mathrm{v}_{\max } 3057,2982,2393,1458$, $1436,1225,1160,1132,1112,1062,1009,991,965,928,895,873,758,746,735,718$, 697, $610 \mathrm{~cm}^{-1}$. HRMS (ESI/Q-TOF) calcd for $\mathrm{C}_{40} \mathrm{H}_{43} \mathrm{~B}_{2} \mathrm{NOP}_{2} \mathrm{Na}[\mathrm{M}+\mathrm{Na}]^{+}: 660.2898$; found: 660.2884. Anal. calcd for $\mathrm{C}_{40} \mathrm{H}_{43} \mathrm{~B}_{2} \mathrm{NOP}_{2}$ : C 75.38, H 6.80, N 2.20; found: C 75.05, H 6.80, N 2.20 .

4.7.11. $\left(R_{p}\right)-(+)-N-[(1 R, 2 S)-2-F e r r o c e n y / p h e n y / p h o s p h i n i t o-b o r a n e)-1-m e t h y l-2-$ phenylethyl], N-methylaminodiphenylphosphine-borane 21g. This compound was synthesized from $\left(R_{p}\right)-(+)-N-[(1 R, 2 S)-2-h y d r o x y-1-m e t h y l-2-$ phenylethyl], $N-$ methylamino(ferroceny/phenyl)phosphine-borane $11 \mathrm{~g}$ previously prepared from (+)ephedrine $9 .{ }^{11 b, 15,30} \mathrm{X}$-ray quality crystals were grown by slow evaporation of $\mathrm{CH}_{2} \mathrm{Cl}_{2}$. The structure and the data were reported in the SI. Orange crystals; $(0.46 \mathrm{~g}, 68 \%$ yield $) ; R_{\mathrm{f}}=$ 
0.60 (toluene); $\mathrm{Mp}=150{ }^{\circ} \mathrm{C} .[\alpha]_{D}{ }^{20}=+9.8\left(\mathrm{c} 0.5, \mathrm{CHCl}_{3}\right) .{ }^{1} \mathrm{H}$ NMR $\left(500 \mathrm{MHz}, \mathrm{CDCl}_{3}\right): \delta$ 0.42-1.46 (m, 6H), $1.28(\mathrm{~d}, J=6.6 \mathrm{~Hz}, 3 \mathrm{H}), 2.19(\mathrm{~d}, J=7.6 \mathrm{~Hz}, 3 \mathrm{H}), 4.02(\mathrm{~s}, 5 \mathrm{H}), 4.09(\mathrm{~m}$, 1H), $4.33(\mathrm{~m}, 1 \mathrm{H}), 4.40(\mathrm{~m}, 2 \mathrm{H}), 4.58(\mathrm{~m}, 1 \mathrm{H}), 5.14(\mathrm{t}, J=9.4 \mathrm{~Hz}, 1 \mathrm{H}), 6.52-6.58(\mathrm{~m}, 2 \mathrm{H})$, 6.95-7.05 (m, 5H), 7.07-7.18 (m, 3H), 7.15-7.17 (m, 1H), 7.19-7.24 (m, 2H), 7.29-7.33 (m, 2H), 7.36-7.40 (m, 1H), 7.42-7.49 (m, 4H). ${ }^{13} \mathrm{C}\left\{{ }^{1} \mathrm{H}\right\} \mathrm{NMR}\left(125.8 \mathrm{MHz}, \mathrm{CDCl}_{3}\right): \delta 15.9,29.4$ (d, $J=4.3 \mathrm{~Hz}), 57.9(\mathrm{dd}, J=10.9,8.1 \mathrm{~Hz}), 70.0,71.1(\mathrm{~d}, J=9.6 \mathrm{~Hz}), 71.5(\mathrm{~d}, J=8.9 \mathrm{~Hz})$, $72.1(\mathrm{~d}, J=7.7 \mathrm{~Hz}), 72.2(\mathrm{~d}, J=14.1 \mathrm{~Hz}), 72.6(\mathrm{~d}, J=85.3 \mathrm{~Hz}), 82.6(\mathrm{dd}, J=8.6,3.3 \mathrm{~Hz})$, 125.3, $127.6(\mathrm{~d}, J=10.7 \mathrm{~Hz}), 128.0(\mathrm{~d}, J=10.6 \mathrm{~Hz}), 128.0,128.1,128.2,128.4(\mathrm{~d}, J=$ 10.0 Hz), 128.6, 128.9 (d, $J=29.0 \mathrm{~Hz}), 129.8(\mathrm{~d}, J=71.3 \mathrm{~Hz}), 130.3(\mathrm{~d}, J=2.4 \mathrm{~Hz}), 130.7$ $(\mathrm{d}, J=57.9 \mathrm{~Hz}), 130.8,131.1(\mathrm{~d}, J=1.8 \mathrm{~Hz}), 131.2(\mathrm{~d}, J=2.1 \mathrm{~Hz}), 131.3(\mathrm{~d}, J=11.2 \mathrm{~Hz})$, $131.7(\mathrm{~d}, J=10.2 \mathrm{~Hz}), 131.9(\mathrm{~d}, J=61.7 \mathrm{~Hz}), 132.5(\mathrm{~d}, J=10.4 \mathrm{~Hz}), 138.3 .{ }^{31} \mathrm{P}\left\{{ }^{1} \mathrm{H}\right\} \mathrm{NMR}$ (202.5 MHz, $\mathrm{CDCl}_{3}$ ): $\delta+71.7$ (br.s), +106.9 (br.s). HRMS (ESI/Q-TOF) calcd for $\mathrm{C}_{38} \mathrm{H}_{43} \mathrm{~B}_{2} \mathrm{FeNOP}_{2} \quad[\mathrm{M}]^{+}: \quad 669.2363$ found: 669.2367. HRMS (ESI/Q-TOF) calcd for $\mathrm{C}_{38} \mathrm{H}_{43} \mathrm{~B}_{2} \mathrm{FeNOP}{ }_{2} \mathrm{Na} \quad[\mathrm{M}+\mathrm{Na}]^{+}:$692.2261; found: 692.2247. Anal. calcd for $\mathrm{C}_{38} \mathrm{H}_{43} \mathrm{~B}_{2} \mathrm{FeNOP}_{2}$ : C 68.21, H 6.48, N 2.09; found: C 68.00, H 6.49, N 2.11.

4.7.12. (Sp)-(-)-N-[(1R,2S)-2-t-Buty/pheny/phosphinito-borane)-1-methyl-2-phenylethyl], $\mathrm{N}$-methyl aminodipheny/phosphine-borane $21 \mathrm{~h}$. This compound was synthesized from $\left(S_{p}\right)-(+)-N-[(1 R, 2 S)-2-h y d r o x y-1-m e t h y l-2-$ phenylethyl], $N$-methylamino(t- 
butyl)phenylphosphine-borane $11 \mathrm{~h}$ previously prepared from (+)-ephedrine $9 .{ }^{11 \mathrm{~b}, 32} \mathrm{X}$-ray quality crystals were grown by slow evaporation of hexane. The structure and the data were reported in the SI. Colorless crystals; $\left(0.32 \mathrm{~g}, 59 \%\right.$ yield); $R_{\mathrm{f}}=0.55$ (toluene); $\mathrm{Mp}=$ $234{ }^{\circ} \mathrm{C} .[\alpha]_{D}{ }^{20}=-93.6\left(\mathrm{c} 1.0, \mathrm{CHCl}_{3}\right) .{ }^{1} \mathrm{H} \mathrm{NMR}\left(300 \mathrm{MHz}, \mathrm{CDCl}_{3}\right): \delta 0.25-1.77(\mathrm{~m}, 6 \mathrm{H}), 1.13$ $(\mathrm{d}, J=14.6 \mathrm{~Hz}, 9 \mathrm{H}), 1.51(\mathrm{~d}, J=6.5 \mathrm{~Hz}, 3 \mathrm{H}), 2.23(\mathrm{~d}, J=7.5 \mathrm{~Hz}, 3 \mathrm{H}), 4.63-4.76(\mathrm{~m}, 1 \mathrm{H})$, $5.26(\mathrm{t}, J=9.5 \mathrm{~Hz}, 1 \mathrm{H}), 6.53-6.63(\mathrm{~m}, 2 \mathrm{H}), 6.96-7.62(\mathrm{~m}, 18 \mathrm{H}) .{ }^{13} \mathrm{C}\left\{{ }^{1} \mathrm{H}\right\} \mathrm{NMR}:(75.5 \mathrm{MHz}$, $\left.\mathrm{CDCl}_{3}\right): \delta 16.7,24.4(\mathrm{~d}, J=2.9 \mathrm{~Hz}), 29.2(\mathrm{~d}, J=4.8 \mathrm{~Hz}), 32.5(\mathrm{~d}, J=44.7 \mathrm{~Hz}), 57.1(\mathrm{dd}, J$ $=11.1,8.6 \mathrm{~Hz}), 82.4(\mathrm{dd}, J=9.2,5.1 \mathrm{~Hz}), 126.9(\mathrm{~d}, J=10.0 \mathrm{~Hz}), 128.0(\mathrm{~d}, J=10.8 \mathrm{~Hz})$, $128.1,128.3,128.5(\mathrm{~d}, J=5.0 \mathrm{~Hz}), 128.7,129.1,129.3(\mathrm{~d}, J=6.8 \mathrm{~Hz}), 130.3(\mathrm{~d}, J=2,4$ $\mathrm{Hz}), 130.4(\mathrm{~d}, J=19.2 \mathrm{~Hz}), 130.8(\mathrm{~d}, J=2.6 \mathrm{~Hz}), 131.1(\mathrm{~d}, J=2.1 \mathrm{~Hz}), 131.6(\mathrm{~d}, J=10.4$ $\mathrm{Hz}), 132.5(\mathrm{~d}, J=10.1 \mathrm{~Hz}), 132.5(\mathrm{~d}, J=10.4 \mathrm{~Hz}), 138.2 .{ }^{31} \mathrm{P}\left\{{ }^{1} \mathrm{H}\right\} \mathrm{NMR}(121.5 \mathrm{MHz}$, $\left.\mathrm{CDCl}_{3}\right): \delta+71.1$ (br.s), +125.5 (br.s). HRMS (ESI/Q-TOF) calcd for $\mathrm{C}_{32} \mathrm{H}_{43} \mathrm{~B}_{2} \mathrm{NOP}_{2} \mathrm{Na}$ $[\mathrm{M}+\mathrm{Na}]^{+}:$564.28982; found: 664.28944 . Anal. calcd for $\mathrm{C}_{32} \mathrm{H}_{43} \mathrm{~B}_{2} \mathrm{NOP}_{2}: \mathrm{C} 71.01, \mathrm{H} 8.01, \mathrm{~N}$ 2.59; found: C 70.92, H 8.39, N 2.65.

4.7.13. $\left(S_{p}\right)-(-)-N-[(1 R, 2 S), \quad 2-($ Phenyl-o-biphenylphosphinito-borane)-1-methyl-2phenylethyl], N-methylamino-dipheny/phosphine-borane 21i. This compound was synthesized from $\quad\left(S_{p}\right)-(+)-N-[(1 R, 2 S)-2-h y d r o x y-1-m e t h y l-2-p h e n y l e t h y l], \quad N$ methylamino(phenyl-o-biphenyl)phosphine-borane $11 \mathrm{i}$ previously prepared from $(+)-$ 
ephedrine 9. White solid; $\left(0.37 \mathrm{~g}, 58 \%\right.$ yield); $R_{\mathrm{f}}=0.58$ (petroleum ether/dichloromethane 1:1); $\mathrm{Mp}=200-202^{\circ} \mathrm{C} .[\alpha]_{D}{ }^{20}=-67.7\left(\mathrm{c} 0.4, \mathrm{CHCl}_{3}\right) .{ }^{1} \mathrm{H}$ NMR: $\left(500 \mathrm{MHz}, \mathrm{CD}_{2} \mathrm{Cl}_{2}\right): \delta 0.47-$ $1.47 \mathrm{~m}, 6 \mathrm{H}), 1.25(\mathrm{~d}, J=6.6 \mathrm{~Hz}, 3 \mathrm{H}), 2.32(\mathrm{~d}, J=7.7 \mathrm{~Hz}, 3 \mathrm{H}), 4.57-4.65(\mathrm{~m}, 1 \mathrm{H}), 5.52(\mathrm{t}, J$ $=8.9 \mathrm{~Hz}, 1 \mathrm{H}), 6.69-6.73(\mathrm{~m}, 2 \mathrm{H}), 6.77-6.79(\mathrm{~m}, 2 \mathrm{H}), 7.05-7.08(\mathrm{~m}, 3 \mathrm{H})$, 7.15-7.38 $(\mathrm{m}$, 21H), 7.84 (ddd, $J=13.5,7.8,1.0 \mathrm{~Hz}, 1 \mathrm{H}) .{ }^{13} \mathrm{C}\left\{{ }^{1} \mathrm{H}\right\} \mathrm{NMR}\left(125.8 \mathrm{MHz}, \mathrm{CD}_{2} \mathrm{Cl}_{2}\right): \delta 16.0,29.3$ (d, $J=4.5 \mathrm{~Hz}), 57.2(\mathrm{dd}, J=11.4,8.6 \mathrm{~Hz}), 83.5(\mathrm{dd}, J=8.9,2.5 \mathrm{~Hz}), 126.4(\mathrm{~d}, J=11.7$ $\mathrm{Hz}), 127.0(2 \mathrm{~s}),$,127.9 (d, $J=10.9 \mathrm{~Hz}), 128.1(\mathrm{~d}, J=10.9 \mathrm{~Hz}), 128.2,,128.4(\mathrm{~d}, J=10.1$ $\mathrm{Hz}), 128.7,129.2,129.5,129.6,130.2(\mathrm{~d}, J=10.9 \mathrm{~Hz}), 130.3(\mathrm{~d}, J=48.4 \mathrm{~Hz}), 130.4(\mathrm{~d}, J$ $=2.3 \mathrm{~Hz}), 130.6(\mathrm{~d}, J=2.3 \mathrm{~Hz}), 130.9(\mathrm{~d}, J=23.4 \mathrm{~Hz}), 131.1(\mathrm{~d}, J=1.6 \mathrm{~Hz}), 131.4(\mathrm{~d}, J=$ $10.2 \mathrm{~Hz}), 131.4,131.7$ (d, $J=10.9 \mathrm{~Hz}), 132.5$ (d, $J=10.2 \mathrm{~Hz}), 133.2(\mathrm{~d}, J=71.8 \mathrm{~Hz})$, $133.9(\mathrm{~d}, J=17.2 \mathrm{~Hz}), 138.0,140.2\left(\mathrm{~d}, J=2.5 \mathrm{~Hz}, 146.1(\mathrm{~d}, J=6.4 \mathrm{~Hz}) .{ }^{31} \mathrm{P}\left\{{ }^{1} \mathrm{H}\right\} \mathrm{NMR}:\right.$ (202.5 MHz, $\quad \mathrm{CD}_{2} \mathrm{Cl}_{2}$ ): $\delta+71.2$ (br.s), +107.7 (br.s). HRMS (ESI/Q-TOF) calcd for $\mathrm{C}_{40} \mathrm{H}_{44} \mathrm{~B}_{2} \mathrm{NOP}_{2}[\mathrm{M}+\mathrm{H}]^{+}$: 638.3092; found: 638.3091 .

\subsection{Typical procedure for the decomplexation of aminophosphine-phosphinite-diborane}

21. A solution of aminophosphine-phosphinite-diborane 21 (1 mmol) and DABCO (4 mmol) in toluene $(3 \mathrm{~mL})$ was heated at $50^{\circ} \mathrm{C}$ with an oil bath and was stirred under argon overnight. After removing the solvent under vacuum, the residue was purified by 
chromatography on neutral aluminium-oxide using a mixture of petroleum ether/ethyl acetate $(4: 1)$ or toluene as eluent, to afford the free $\mathrm{AMPP}^{*} 20$.

4.8.1. $\quad\left(R_{p}\right)-N-[(1 R, 2 S)-2-(0-A n i s y l p h e n y l p h o s p h i n i t o)-1-m e t h y l-2-p h e n y l e t h y l], \quad N-$ methylamino diphenylphosphine 20a. $0.49 \mathrm{~g}, 87 \%$ yield; White sticky solid; $R_{\mathrm{f}}=0.70$ (petroleum ether/ethyl acetate 4:1). ${ }^{1} \mathrm{H} \mathrm{NMR}\left(500 \mathrm{MHz}, \mathrm{CDCl}_{3}\right): \delta 1.34(\mathrm{~d}, J=6.6 \mathrm{~Hz}, 3 \mathrm{H})$, $2.13(\mathrm{~d}, J=3.0 \mathrm{~Hz}, 3 \mathrm{H}), 3.61(\mathrm{~s}, 3 \mathrm{H}), 3.89-3.95(\mathrm{~m}, 1 \mathrm{H}), 4.78(\mathrm{t}, J=8.7 \mathrm{~Hz}, 1 \mathrm{H}), 6.56-6.59$ $(\mathrm{m}, 2 \mathrm{H}), 6.72(\mathrm{dd}, J=8.2,4.6 \mathrm{~Hz}, 1 \mathrm{H}), 6.95-7.11(\mathrm{~m}, 13 \mathrm{H}), 7.19-7.25(\mathrm{~m}, 7 \mathrm{H}), 7.53(\mathrm{ddd}, J$ $=7.3,4.2,1.6 \mathrm{~Hz}, 1 \mathrm{H}) .{ }^{31} \mathrm{P}\left\{{ }^{1} \mathrm{H}\right\} \operatorname{NMR}\left(202.5 \mathrm{MHz}, \mathrm{CDCl}_{3}\right): \delta+64.9,+101.3$.

4.8.2. $\quad\left(S_{p}\right)-N-[(1 S, 2 R)-2-(0-A n i s y l p h e n y l p h o s p h i n i t o)-1-m e t h y l-2-p h e n y l e t h y l], \quad N-$ methylamino diphenylphosphine 20a. $0.48 \mathrm{~g}, 85 \%$ yield; White sticky solid; $R_{\mathrm{f}}=0.74$ (petroleum ether/ethyl acetate 4:1). ${ }^{1} \mathrm{H}$ NMR (500 MHz, $\left.\mathrm{CDCl}_{3}\right): \delta 1.19(\mathrm{~d}, J=6.5 \mathrm{~Hz}, 3 \mathrm{H})$, $2.10(\mathrm{~d}, J=3.1 \mathrm{~Hz}, 3 \mathrm{H}), 3.47(\mathrm{~s}, 3 \mathrm{H}), 3.85-3.95(\mathrm{~m}, 1 \mathrm{H}), 4.70(\mathrm{t}, J=9.1 \mathrm{~Hz}, 1 \mathrm{H}), 6.57-6.60$ $(\mathrm{m}, 2 \mathrm{H}), 6.77-6.80(\mathrm{~m}, 1 \mathrm{H}), 6.99-7.20(\mathrm{~m}, 13 \mathrm{H}), 7.23-7.32(\mathrm{~m}, 7 \mathrm{H})$, 7.43-7.52 (m, 1H). ${ }^{31} \mathrm{P}\left\{{ }^{1} \mathrm{H}\right\} \operatorname{NMR}\left(202.5 \mathrm{MHz}, \mathrm{CDCl}_{3}\right): \delta+65.2,+102.0$

4.8.3. $\quad\left(R_{p}\right)-N-[(1 R, 2 S)-2-(\alpha-N a p h t y l p h e n y l p h o s p h i n i t o)-1-m e t h y l-2-p h e n y l e t h y l], \quad N-$ methyl aminodiphenylphosphine 20b. $0.53 \mathrm{~g}, 91 \%$ yield; White sticky solid; $R_{\mathrm{f}}=0.70$ (toluene). ${ }^{1} \mathrm{H}$ NMR (500 MHz, $\left.\mathrm{CDCl}_{3}\right): \delta 1.22(\mathrm{~d}, J=6.6 \mathrm{~Hz}, 3 \mathrm{H}), 2.10(\mathrm{~d}, J=3.0 \mathrm{~Hz}, 3 \mathrm{H})$, 3.91-3.96 (m, 1H), $4.80(\mathrm{t}, J=8.9 \mathrm{~Hz}, 1 \mathrm{H}), 6.56-6.59(\mathrm{~m}, 2 \mathrm{H}), 6.97-7.21(\mathrm{~m}, 16 \mathrm{H}), 7.30-$ 
$7.32(\mathrm{~m}, 3 \mathrm{H}), 7.34-7.36(\mathrm{~m}, 1 \mathrm{H}), 7.44-7.48(\mathrm{~m}, 1 \mathrm{H}), 7.78(\mathrm{dd}, J=17.5,8.1 \mathrm{~Hz}, 2 \mathrm{H}), 7.92$

$(\mathrm{td}, J=7.2,1.1 \mathrm{~Hz}, 1 \mathrm{H}), 8.18(\mathrm{dd}, J=2.1,8.4 \mathrm{~Hz}, 1 \mathrm{H}) .{ }^{31} \mathrm{P}\left\{{ }^{1} \mathrm{H}\right\} \operatorname{NMR}\left(202.5 \mathrm{MHz}, \mathrm{CDCl}_{3}\right): \delta$ $+64.7,+107.4$.

4.8.4. $\quad\left(S_{p}\right)-N-[(1 S, 2 R)-2-(\alpha-N a p h t y l p h e n y l p h o s p h i n i t o)-1-m e t h y l-2-p h e n y l e t h y l], \quad N-$ methyl aminodiphenylphosphine 20b. ${ }^{31} \mathrm{P}\left\{{ }^{1} \mathrm{H}\right\} \mathrm{NMR}\left(202.5 \mathrm{MHz}, \mathrm{CDCl}_{3}\right): \delta+64.3,+108.4$.

4.8.5. ( $\quad\left(R_{p}\right)-N-[(1 R, 2 S)-2-(\beta-N a p h t y l p h e n y l p h o s p h i n i t o)-1-m e t h y l-2-p h e n y l e t h y l], \quad N-$ methyl aminodiphenylphosphine 20c. $0.52 \mathrm{~g}, 89 \%$ yield; White sticky solid; $R_{\mathrm{f}}=0.60$ (toluene). ${ }^{1} \mathrm{H}$ NMR (500 MHz, $\left.\mathrm{CDCl}_{3}\right): 1.28(\mathrm{~d}, J=6.6 \mathrm{~Hz}, 3 \mathrm{H}), 2.12(\mathrm{~d}, J=3.1 \mathrm{~Hz}, 3 \mathrm{H})$, 3.89-3.99 (m, 1H), $4.76(t, J=8.9 \mathrm{~Hz}, 1 \mathrm{H}), 6.57-6.60(\mathrm{~m}, 2 \mathrm{H}),, 6.95-6.99(\mathrm{~m}, 2 \mathrm{H}), 7.05-$ $7.20(\mathrm{~m}, 13 \mathrm{H}), 7.29-7.32(\mathrm{~m}, 2 \mathrm{H}), 7.42-7.44(\mathrm{~m}, 3 \mathrm{H}), 7.70-7.80(\mathrm{~m}, 4 \mathrm{H}), 8.06(\mathrm{~d}, J=9.9$ $\mathrm{Hz}, 1 \mathrm{H}) .{ }^{31} \mathrm{P}\left\{{ }^{1} \mathrm{H}\right\} \mathrm{NMR}\left(202.5 \mathrm{MHz}, \mathrm{CDCl}_{3}\right): \delta+64.8,+110.5$.

4.8.6. ( $\quad\left(R_{p}\right)-N-[(1 R, 2 S)-2-(P h e n y l-o-t o l y l p h o s p h i n i t o)-1-m e t h y l-2-p h e n y l e t h y l], \quad N-$ methylamino diphenylphosphine $20 \mathrm{~d} .0 .51 \mathrm{~g}, 90 \%$ yield; White sticky solid; $R_{\mathrm{f}}=0.65$ (toluene). ${ }^{1} \mathrm{H}$ NMR $\left(500 \mathrm{MHz}, \mathrm{CDCl}_{3}\right): \delta 1.31(\mathrm{~d}, J=6.6 \mathrm{~Hz}, 3 \mathrm{H}), 2.13(\mathrm{~d}, J=3.1 \mathrm{~Hz}, 3 \mathrm{H})$, $2.16(\mathrm{~s}, 3 \mathrm{H}), 3.82-3.98(\mathrm{~m}, 1 \mathrm{H}), 4.74(\mathrm{t}, J=8.6 \mathrm{~Hz}, 1 \mathrm{H}), 6.57-6.60(\mathrm{~m}, 2 \mathrm{H})$, 6.98-7.21 (m, 21H), 7.71-7.73 (m, 1H). ${ }^{31} \mathrm{P}\left\{{ }^{1} \mathrm{H}\right\} \operatorname{NMR}\left(202.5 \mathrm{MHz}, \mathrm{CDCl}_{3}\right): \delta+64.7,+104.7$. 4.8.7. (Rp)-N-[(1R,2S)-2-(Phenyl-p-tolylphosphinito)-1-methyl-2-phenylethyl], $\quad N$ methylamino diphenylphosphine 20e. ${ }^{31} \mathrm{P}\left\{{ }^{1} \mathrm{H}\right\} \mathrm{NMR}\left(202.5 \mathrm{MHz}, \mathrm{CDCl}_{3}\right): \delta+64.5,+112.5$. 
4.8.8. ( $\quad\left(R_{p}\right)-N-[(1 R, 2 S)-2-(P h e n y l-o-b i p h e n y l p h o s p h i n i t o)-1-m e t h y l-2-p h e n y l e t h y l], \quad N-$

methyl amino-diphenylphosphine 20f. $0.66 \mathrm{~g}, 94 \%$ yield; White sticky solid; $R_{\mathrm{f}}=0.75$ (petroleum ether/ ethyl acetate 4:1). ${ }^{1} \mathrm{H}$ NMR (300 MHz, $\left.\mathrm{CD}_{2} \mathrm{Cl}_{2}\right): \delta 1.35(\mathrm{~d}, J=6.3 \mathrm{~Hz}$, 3H), $2.19(\mathrm{~d}, J=3.2 \mathrm{~Hz}, 3 \mathrm{H}), 3.90-4.00(\mathrm{~m}, 1 \mathrm{H}), 4.68(\mathrm{t}, J=8.7 \mathrm{~Hz}, 1 \mathrm{H}), 6.65-6.70(\mathrm{~m}, 2 \mathrm{H})$, 6.98-7.03 (m, 2H), 7.07-7.15 (m, 4H), 7.16-7.27 (m, 12H), 7.28-7.35 (m, 6H), 7.42-7.52 (m, 2H), 7.90-8.00 (m, 1H). ${ }^{31} \mathrm{P}\left\{{ }^{1} \mathrm{H}\right\} \operatorname{NMR}\left(121.5 \mathrm{MHz}, \mathrm{CD}_{2} \mathrm{Cl}_{2}\right): \delta+64.9,+101.9$.

4.8.9. (R $\left.\left.R_{p}\right)-(+)-N-[(1 R, 2 S)-2-F e r r o c e n y l p h e n y l p h o s p h i n i t o)-1-m e t h y l-2-p h e n y l e t h y l\right], \quad N-$ methyl aminodiphenylphosphine $20 \mathrm{~g} .0 .56 \mathrm{~g}, 88 \%$ yield; Orange sticky solid; $R_{\mathrm{f}}=0.60$ (toluene). ${ }^{1} \mathrm{H}$ NMR (300 MHz, $\left.\mathrm{CDCl}_{3}\right): \delta 1.27(\mathrm{~d}, J=6.7 \mathrm{~Hz}, 3 \mathrm{H}), 2.13(\mathrm{~d}, J=3.2 \mathrm{~Hz}, 3 \mathrm{H})$, $3.67(\mathrm{~m}, 1 \mathrm{H}), 3.74-3.85(\mathrm{~m}, 1 \mathrm{H}), 4.00(\mathrm{~s}, 5 \mathrm{H}), 4.19(\mathrm{~m}, 1 \mathrm{H}), 4.29(\mathrm{~m}, 1 \mathrm{H}), 4.36(\mathrm{~m}, 1 \mathrm{H})$, $4.71(\mathrm{t}, J=9.0 \mathrm{~Hz}, 1 \mathrm{H}), 6.63-6.68(\mathrm{~m}, 2 \mathrm{H}), 7.01-7.20(\mathrm{~m}, 16 \mathrm{H}), 7.40-7.45(\mathrm{~m}, 2 \mathrm{H})$. ${ }^{31} \mathrm{P}\left\{{ }^{1} \mathrm{H}\right\} \operatorname{NMR}\left(121.5 \mathrm{MHz}, \mathrm{CDCl}_{3}\right): \delta+64.7(\mathrm{~s}),+105.5(\mathrm{~s})$.

4.8.10. $\left.\quad\left(S_{p}\right)-(-)-N-[(1 R, 2 S)-2-t-B u t y l p h e n y l p h o s p h i n i t o)-1-m e t h y l-2-p h e n y l e t h y l\right], \quad N-$ methylamino diphenylphosphine 20h. ${ }^{1} \mathrm{P}\left\{{ }^{1} \mathrm{H}\right\} \mathrm{NMR}\left(121.5 \mathrm{MHz}, \mathrm{CD}_{2} \mathrm{Cl}_{2}\right): \delta+66.4,+129.4$.

4.8.11. (S $\left.S_{p}\right)-N-[(1 R, 2 S)-2-(P h e n y l-o-b i p h e n y l p h o s p h i n i t o)-1-m e t h y l-2-p h e n y l e t h y l], \quad N-$ methyl aminodiphenylphosphine 20i. $0.54 \mathrm{~g}, 88 \%$ yield; White sticky solid; $R_{\mathrm{f}}=0.74$ (petroleum ether/ethyl acetate 4:1). ${ }^{1} \mathrm{H}$ NMR (300 MHz, $\left.\mathrm{CDCl}_{3}\right): \delta 1.15(\mathrm{~d}, J=6.8 \mathrm{~Hz}, 3 \mathrm{H})$, $2.05(\mathrm{~d}, J=4.0 \mathrm{~Hz}, 3 \mathrm{H}), 3.81-3.90(\mathrm{~m}, 1 \mathrm{H}), 4.63(\mathrm{t}, J=8.1 \mathrm{~Hz}, 1 \mathrm{H}), 6.52-6.57(\mathrm{~m}, 2 \mathrm{H})$, 
6.81-6.85 (m, 2H), 6.96-7.21 (m, 24H), 7.58-7.62 (m, 1H). ${ }^{31} \mathrm{P}\left\{{ }^{1} \mathrm{H}\right\} \mathrm{NMR}(121.5 \mathrm{MHz}$, $\left.\mathrm{CDCl}_{3}\right): \delta+65.1,+104.8$

\subsection{Preparation of dichloropalladium-AMPP* complexes $30-32$.}

4.9.1. General procedure: In a Schlenck tube, under an argon atmosphere, $26.8 \mathrm{mg}$ (0.104 mmol) of $\mathrm{Pd}\left(\mathrm{CH}_{3} \mathrm{CN}\right)_{2} \mathrm{Cl}_{2}$ and $2 \mathrm{~mL}$ of anhydrous dichloromethane were introduced. A solution of $0.104 \mathrm{mmol}$ (1 equivalent) of decomplexed AMPP $\left(R_{\mathrm{p}}\right)-13 \mathrm{f},\left(R_{\mathrm{p}}\right)-13 \mathrm{~g}$ or $\left(R_{\mathrm{p}}\right)-$ $20 \mathrm{~b}$ in $3 \mathrm{~mL}$ of dry dichloromethane was added. The mixture was then stirred at room temperature for $15 \mathrm{~min}$. The solvents were evaporated under vaccuo and the crude solid was recrystallized using a mixture of $\mathrm{CH}_{2} \mathrm{Cl}_{2}$ /toluene or toluene/hexane.

4.9.2. N-[(1R,2S)-(2-(Diphenylphosphinito)-1-methyl-2-phenylethyl], $\quad N$-methylamino(obiphenyl) phenylphosphine dichloropalladium complex 30 . Recrystallization in mixture of $\mathrm{CH}_{2} \mathrm{Cl}_{2}$ /toluene; Colorless crystals; X-ray quality crystals were grown by slow evaporation of $\mathrm{CH}_{2} \mathrm{Cl}_{2}$. The structure and the data were reported in the $\mathrm{SI}$. $[\alpha]_{\mathrm{D}}^{20}=+214$ (c $0.2, \mathrm{CHCl}_{3}$ ); $\mathrm{Mp}=288{ }^{\circ} \mathrm{C} .{ }^{1} \mathrm{H}$ NMR $\left(400 \mathrm{MHz}, \mathrm{CD}_{2} \mathrm{Cl}_{2}\right): \delta 0.00(\mathrm{~d}, J=8.0 \mathrm{~Hz}, 3 \mathrm{H}), 1.92(\mathrm{~d}, J=7.2 \mathrm{~Hz}$, 3H), 3.93 (br.s, 1H), 4.23-4.24 (m, 1H), 6.85 (dd, J=14.2 Hz, $7.9 \mathrm{~Hz}, 1 \mathrm{H})$, 6.96-6.98 (m, 2H), 7.15-7.35 (m, 8H), 7.46-7.73 (m, 14H), 7.92-7.96 (m, 2H), 8.14-8.56 (br.s, 2H). ${ }^{13} \mathrm{C}\left\{{ }^{1} \mathrm{H}\right\} \operatorname{NMR}\left(100.6 \mathrm{MHz}, \mathrm{CD}_{2} \mathrm{Cl}_{2}\right): \delta 12.8(\mathrm{~d}, J=6.0 \mathrm{~Hz}), 33.9(\mathrm{~d}, J=4.4 \mathrm{~Hz}), 59.0(\mathrm{t}, J=$ $9.9 \mathrm{~Hz}), 82.2(\mathrm{~d}, J=4.5 \mathrm{~Hz}), 126.4(\mathrm{~d}, J=11.2 \mathrm{~Hz}), 127.2,127.7,127.9(\mathrm{~d}, J=11.9 \mathrm{~Hz})$, 
$128.2(\mathrm{~d}, J=9.8 \mathrm{~Hz}), 128.5,128.6,128.7,129.6,129.8(\mathrm{~d}, J=53.8 \mathrm{~Hz}), 130.7,131.1(\mathrm{~d}, J$

$=2.1 \mathrm{~Hz}), 131.6(\mathrm{~d}, J=45.4 \mathrm{~Hz}), 131.6(\mathrm{~d}, J=2.8 \mathrm{~Hz}), 131.7(\mathrm{~d}, J=2.1 \mathrm{~Hz}), 132.2(\mathrm{~d}, J=$ $11.2 \mathrm{~Hz}), 133.0(\mathrm{~d}, J=2.1 \mathrm{~Hz}), 133.1(\mathrm{~d}, J=9.1 \mathrm{~Hz}), 134.4(\mathrm{~d}, J=10.2 \mathrm{~Hz}), 134.6(\mathrm{~d}, J=$ $57.8 \mathrm{~Hz}), 134.9(\mathrm{~d}, J=12.7 \mathrm{~Hz}), 135.1,142.8(\mathrm{~d}, J=9.3 \mathrm{~Hz}), 143.9(\mathrm{~d}, J=8.3 \mathrm{~Hz}) .{ }^{31} \mathrm{P}\left\{{ }^{1} \mathrm{H}\right\}$ NMR $\left(161.9 \mathrm{MHz}, \mathrm{CD}_{2} \mathrm{Cl}_{2}\right): \delta+95.6(\mathrm{~d}, J=42.0 \mathrm{~Hz}),+106.2(\mathrm{~d}, J=42.0 \mathrm{~Hz})$. FTIR (neat): $v_{\max } 3054,2991,2891,2835,1480,1463,1444,1434,1382,1376,1230,1207$, 1182, 1158, 1134, 1101, 1084, 1072, 1029, 1018, 996, 944, 921, 896, 841, 833, 743, 732, 712, 689, 677, 653. Anal. calcd for $\mathrm{C}_{40} \mathrm{H}_{37} \mathrm{NOP}_{2} \mathrm{Cl}_{2} \mathrm{Pd}, \mathrm{H}_{2} \mathrm{O}$ : C 59.70, H 4.88, N 1.74; found: C 59.83, H 4.82, N 2.22.

4.9.3. $\left(R_{\mathrm{p}}\right)-\mathrm{N}-[(1 R, 2 S)-(2-(D i p h e n y /$ phosphinito)-1-methyl-2-phenylethyl], $\mathrm{N}$-methylamino ferroceny/pheny/phosphine dichloropalladium complex 31. Recrystallization in a mixture of toluene/hexane; orange crystals; X-ray quality crystals were grown by slow evaporation of $\mathrm{CH}_{2} \mathrm{Cl}_{2}$. The structure and the data were reported in the SI. $[\alpha]_{D}{ }^{20}=-177$ (c $\left.0.5, \mathrm{CHCl}_{3}\right) ; \mathrm{Mp}$ $=250{ }^{\circ} \mathrm{C} .{ }^{1} \mathrm{H} \operatorname{NMR}\left(300 \mathrm{MHz}, \mathrm{CDCl}_{3}\right): \delta 0.81(\mathrm{~d}, J=6.8 \mathrm{~Hz}, 3 \mathrm{H}), 2.10(\mathrm{~d}, J=11.9 \mathrm{~Hz}, 3 \mathrm{H})$, 3.85 (br.s, 1H), $4.03(\mathrm{~s}, 5 \mathrm{H}), 4.53(\mathrm{~s}, 1 \mathrm{H}), 4.70(\mathrm{~s}, 2 \mathrm{H}), 5.40-5.51(\mathrm{~m}, 2 \mathrm{H}), 6.56-6.58(\mathrm{~m}$, 2H), 7.00-7.19 (m, 7H), 7.42-7.63 (m, 7H), 8.27-8.33 (m, 4H). ${ }^{13} \mathrm{C}\left\{{ }^{1} \mathrm{H}\right\}$ NMR $(75.5 \mathrm{MHz}$, $\left.\mathrm{CDCl}_{3}\right): \delta 13.7(\mathrm{~d}, J=4.3 \mathrm{~Hz}), 29.6,33.7(\mathrm{~d}, J=4.9 \mathrm{~Hz}), 53.4,56.8,71.2(\mathrm{~d}, J=11.8 \mathrm{~Hz})$, 71.5, $72.4(\mathrm{~d}, J=67 \mathrm{~Hz}), 72.8(\mathrm{~d}, J=3.4 \mathrm{~Hz}), 79.3-79.4(\mathrm{~m}), 79.7,125.2,127.5,127.6$, 
$127.7(\mathrm{~d}, J=4.8 \mathrm{~Hz}), 127.9,128.5(\mathrm{~d}, J=11.6 \mathrm{~Hz}), 128.6(\mathrm{~d}, J=60.9 \mathrm{~Hz}), 131.4-131.5$ (m), $132.0(\mathrm{~d}, J=2.8 \mathrm{~Hz}), 132.0(\mathrm{~d}, J=65.0 \mathrm{~Hz}), 132.9,133.0,133.2,133.8,134.5(\mathrm{~d}, J=$ $54.4 \mathrm{~Hz}), 134.6(\mathrm{~d}, J=12.9 \mathrm{~Hz}), 134.8,136.1(\mathrm{~d}, J=2.6 \mathrm{~Hz}) .{ }^{31} \mathrm{P}\left\{{ }^{1} \mathrm{H}\right\} \mathrm{NMR}(121.5 \mathrm{MHz}$, $\left.\mathrm{CDCl}_{3}\right): \delta+132.0(\mathrm{~d}, J=33.8 \mathrm{~Hz}),+87.4(\mathrm{~d}, J=33.8 \mathrm{~Hz})$. FTIR (neat): $v_{\max } 2963,1481$, 1258, 1081, 1012, 791, 688.

4.9.4. $\quad\left(R_{p}\right)-N-[(1 R, 2 S)-2-(\alpha-N a p h t y l p h e n y l p h o s p h i n i t o)-1-m e t h y l-2-p h e n y l e t h y l], \quad N-$ methylamino diphenylphosphine dichloropalladium complex 32. X-ray quality crystals were grown by slow evaporation of $\mathrm{CH}_{2} \mathrm{Cl}_{2}$. The structure and the data were reported in the SI;

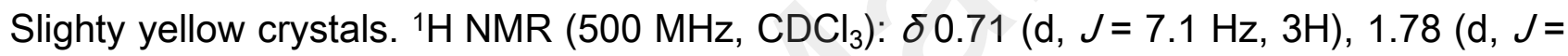
9.7 Hz, 3H), 4.83-4.95 (m, 2H), 7.20-7.33 (m, 7H), 7.36-7.53 (m, 10H), 7.55-7.59 (m, 1H), 7.72-7.83 $(\mathrm{m}, 4 \mathrm{H}), 7.85-7.90(\mathrm{~m}, 1 \mathrm{H}), 8.06-8.17(\mathrm{~m}, 4 \mathrm{H}) .{ }^{13} \mathrm{C}\left\{{ }^{1} \mathrm{H}\right\}$ NMR $(125.8 \mathrm{MHz}$, $\left.\mathrm{CDCl}_{3}\right): \delta 14.0(\mathrm{~d}, J=2.8 \mathrm{~Hz}), 33.4(\mathrm{~d}, J=5.8 \mathrm{~Hz}), 56.3(\mathrm{t}, J=8.3 \mathrm{~Hz}), 83.7(\mathrm{t}, J=4.7 \mathrm{~Hz})$, $124.2(\mathrm{~d}, J=14.4 \mathrm{~Hz}), 126.2,126.7,126.8,127.0(\mathrm{~d}, J=8.4 \mathrm{~Hz}), 128.1,128.2,128.6(\mathrm{~d}, J$ $=10.0 \mathrm{~Hz}), 128.6,128.7(\mathrm{~d}, J=5.3 \mathrm{~Hz}), 129.1(\mathrm{~d}, J=75.5 \mathrm{~Hz}), 129.2,130.0(\mathrm{~d}, J=56.1$ $\mathrm{Hz}), 131.3(\mathrm{~d}, J=2.2 \mathrm{~Hz}), 131.6(\mathrm{~d}, J=2.5 \mathrm{~Hz}), 132.1(\mathrm{~d}, J=51.2 \mathrm{~Hz}), 132.6(\mathrm{~d}, J=9.1$ $\mathrm{Hz}), 132.7$ (d, J=2.0 Hz), 132.9 (d, J=2.6 Hz), $133.0(\mathrm{~d}, J=11.7 \mathrm{~Hz}), 133.3(\mathrm{~d}, J=10.4$ $\mathrm{Hz}), 133.9(\mathrm{~d}, J=8.7 \mathrm{~Hz}), 134.9(\mathrm{~d}, J=12.8 \mathrm{~Hz}), 135.4(\mathrm{~d}, J=12.8 \mathrm{~Hz}), 135.4(\mathrm{~d}, J=12.8$ 
$\mathrm{Hz}), 135.7(\mathrm{~d}, J=7.0 \mathrm{~Hz}) .{ }^{31} \mathrm{P}\left\{{ }^{1} \mathrm{H}\right\} \operatorname{NMR}\left(202.5 \mathrm{MHz}, \mathrm{CDCl}_{3}\right): \delta+96.8(\mathrm{~d}, J=47.3 \mathrm{~Hz})$,
$+116.3(\mathrm{~d}, J=47.3 \mathrm{~Hz})$.

4.10. Allylic alkylation of ( \pm )-1,3-diphenylpropenyl acetate 24 with dimethylmalonate or benzylamine.

4.10.1. General procedure: In a flask under argon atmosphere was introduced AMPP* ligand $(0.02$ or $0.04 \mathrm{mmol}),\left[\mathrm{Pd}\left(\mathrm{C}_{3} \mathrm{H}_{5}\right) \mathrm{Cl}\right]_{2}(0.01$ or $0.02 \mathrm{mmol})$ and allylic acetate $(1 \mathrm{mmol})$ in dry dichloromethane $(3 \mathrm{~mL})$. After stirring the solution for one hour at room temperature, dimethylmalonate or benzylamine $(2 \mathrm{mmol})$ was added, followed by $\mathrm{N}, \mathrm{O}$ bis(trimethylsilyl)acetamide $(2 \mathrm{mmol})$ and potassium acetate $(10 \mathrm{mg})$ or TBAF $(2 \mathrm{mmol})$, respectively. After complete reaction, the mixture was successively diluted with $\mathrm{Et}_{2} \mathrm{O}$ (5 $\mathrm{mL}$ ), washed with saturated $\mathrm{NH}_{4} \mathrm{Cl}$ solution and extracted with $\mathrm{Et}_{2} \mathrm{O}$. The combinated organic layers were dried over $\mathrm{MgSO}_{4}$ and filtered. The solvent was removed under vacuum to afford a residue which was purified by chromatography on silica gel using a mixture of petroleum ether/ethyl acetate (5:1) as eluent, to afford the allylated products 25 or 29 as colorless oils.

4.10.2. Procedure for oxidizable ligands: In the case of oxidizable ligand such as AMPP* 13j $\left(R^{1}=M e\right)$, the purification after decomplexation of the ligand by short filtration on neutral alumina led to impure compound. The palladium catalyst was prepared according 
to a one pot procedure. First, the AMPP* $\left(\mathrm{BH}_{3}\right)_{2}$ and $\mathrm{DABCO}$ (4 equiv.) were heated at $50^{\circ} \mathrm{C}$ in toluene with an oil bath for $12 \mathrm{~h}$. After removing the solvent under vacuum, the crude AMPP* ligand was then mixed with $\left[\mathrm{Pd}\left(\mathrm{C}_{3} \mathrm{H}_{5}\right) \mathrm{Cl}\right]_{2}$ in dichloromethane at room temperature for $20 \mathrm{~min}$ and the complex was used without further purification.

4.10.3. Dimethyl (1,3-diphenylallyl)malonate $28:{ }^{1} \mathrm{H} \mathrm{NMR}\left(300 \mathrm{MHz}, \mathrm{CDCl}_{3}\right): \delta 3.44(\mathrm{~s}$, $3 \mathrm{H}), 3.63), 3.88(\mathrm{~d}, J=10.9 \mathrm{~Hz}, 1 \mathrm{H}), 4.19(\mathrm{dd}, J=10.9,8.5 \mathrm{~Hz}, 1 \mathrm{H}), 6.25(\mathrm{dd}, J=15.8,8.5$ $\mathrm{Hz}, 1 \mathrm{H}), 6.41(\mathrm{~d}, J=15.8 \mathrm{~Hz}, 1 \mathrm{H}), 7.09-7.28(\mathrm{~m}, 10 \mathrm{H}) .{ }^{13} \mathrm{C}\left\{{ }^{1} \mathrm{H}\right\} \mathrm{NMR}\left(75 \mathrm{MHz}, \mathrm{CDCl}_{3}\right): \delta$ $49.2,52.5,52.7,57.7,126.4,127.2,127.6,127.9,128.5,128.7,129.1,131.9,136.8,140.2$ 167.8, 168.2. The enantiomeric excess was determined by HPLC analysis on Chiralpack IA, $1.00 \mathrm{~mL} / \mathrm{min}$, hexane/isopropanol $(9: 1), \mathrm{t}(R)=8.5 \mathrm{~min}, \mathrm{t}(S)=10.4 \mathrm{~min}$. The absolute configuration could also be determinated by comparison of the optical rotation to literature value: $[\alpha]_{D}{ }^{25}=-22.4\left(\mathrm{c} 1.8, \mathrm{CHCl}_{3}\right)$ for $(\mathcal{S})$-enantiomer. ${ }^{35}$ 4.10.4. $\mathrm{N}-\left(1,3-\right.$ Diphenylallyl), $\mathrm{N}$-benzylamine 29: ${ }^{1} \mathrm{H} \mathrm{NMR}\left(500 \mathrm{MHz}, \mathrm{CDCl}_{3}\right): \delta 3.79-3.87$ (m, 2H), $4.45(\mathrm{~d}, J=7.5 \mathrm{~Hz}, 1 \mathrm{H}), 6.38(\mathrm{dd}, J=15.8,7.5 \mathrm{~Hz}, 1 \mathrm{H}), 6.61(\mathrm{~d}, J=15.8 \mathrm{~Hz}, 1 \mathrm{H})$, 7.21-7.26 (m, 1H), 7.28-7.34 (m, 4H), 7.36-7.42 (m, 8H), 7.44-7.51 (m, 2H). ${ }^{13} \mathrm{C}\left\{{ }^{1} \mathrm{H}\right\}$ NMR $\left(125 \mathrm{MHz}, \mathrm{CDCl}_{3}\right): \delta 51.4,64.6,126.4,127.0,127.3,127.4,127.5,128.2,128.5,128.5$, $128.7,130.4,132.7,137.0,140.5,142.9$. The enantiomeric excess was determined by 


\begin{abstract}
HPLC analysis on Lux $5 \mu \mathrm{m}$ cellulose-1, $0.5 \mathrm{~mL} / \mathrm{min}$, hexane/isopropanol $(98: 2), \mathrm{t}(R)=20.9$
$\min , \mathrm{t}(S)=22.2 \min$
\end{abstract}

\title{
ASSOCIATED CONTENT
}

\section{Supporting Information}

${ }^{1} \mathrm{H},{ }^{13} \mathrm{C}\left\{{ }^{1} \mathrm{H}\right\},{ }^{31} \mathrm{P}\left\{{ }^{1} \mathrm{H}\right\}$ NMR spectra, X-ray structures with crystallographic data, HPLC chromatograms on chiral column, catalysis complementary results and computational calculations are reported in part A, B and C, respectively. This material is available free of charge via the internet at http://pubs.acs.org.

\section{AUTHOR INFORMATION}

\section{Corresponding Authors}

* E-mail: Sylvain.Juge@u-bourgogne.fr

\section{Present Address}

§ Oril Industrie, 76210- Bolbec- France

${ }^{\delta}$ RTP France, ZI Beaune-Vignolles 21207- Beaune Cedex- France

Note: This work is the subject in part of the patent C-bulky P-chirogenic organophosphorus compounds WO 2019/180084 (2019 sept. 26 $\left.{ }^{\text {th }}\right)$. 


\section{ACKNOWLEDGMENTS}

The authors are grateful for A.J. fellowship and financial support provided by the "Ministère de l'éducation nationale de l'enseignement supérieur et de la recherche", the "Conseil régional de Bourgogne" (research programs 3MIM, PARI santé, CD2A), the Satt-SAYENS, the CNRS (Centre National de la Recherche Scientifique) and the FEDER (Fond Européen de Développement Régional). The authors would like also to thank Ms. M. J. Penouilh, F. Chaux, Mrs M. Picquet, Q. Bonin and E. Closier at the Satt-Sayens for spectroscopy analyses and valuation, Ms E. Pousson and M. M. Soustelle for the elemental analyses, M P. Richard for X-ray structures, Ms N. Khiri-Meribout, M. J. Eymin and M. M. Lagrelette, D. Moulin, P. Rasque and J. Rey for synthesis. PDH acknowledges the Natural Science and Engineering Research Council of Canada for funding. Ms L. Qin at the University of New South Wales, Australia, is warmly thanked for his help to the preparation of this manuscript.

\section{REFERENCE}

(1) (a) Comprehensive Asymmetric Catalysis, Jacobsen, E. N., Pfaltz, A., Yamamoto, H., Eds.; Springer: New York, 1999; Vols. I-III, Suppl. I-II (2004). (b) Phosphorus Ligands in Asymmetric Catalysis: Synthesis and Applications, Börner, A., Ed.; Wiley-VCH: Weinheim, 
Germany, 2008; Vol 1-3. (c) Phosphorus (III) Ligands in Homogeneous Catalysis: Design and Synthesis, Kamer, P. C. J., van Leeuwen, P. W. N. M., Eds, Wiley, Chichester, U.K., 2012.

(2) Comprehensive Chirality, Carreira, E. M., Yamamoto, H., Eds.; Elsevier Science: Amsterdam, 2012; Vols. 1-9.

(3) (a) Denmark, S. E.; Beutner, G. L. Lewis base catalysis in organic synthesis. Angew. Chem. Int. Ed. 2008, 47, 1560-1638. (b) Werner, T. Phosphonium Salt Organocatalysis. Adv. Synth. Catal. 2009, 351, 1469-1481. (c) Enders, D.; Nguyen, T. V. Chiral quaternary phosphonium salts: a new class of organocatalysts. Org. Biomol. Chem. 2012, 10, 53275331. (d) Li, X.; Song, Q. Recent advances in asymmetric catalyzed by chiral phosphoric acids. Chin. Chem. Lett. 2018, 29, 1181-1192. (e) Ni, H.; Chan, W.-L.; Lu, X. Phosphinecatalyzed asymmetric organic reactions. Chem. Rev. 2018, 118, 9344-9411.

(4) (a) P-Stereogenic ligands in enantioselective catalysis, Grabulosa, A., Ed.; RSC Catalysis Series, Cambridge, U.K., 2011. (b) Kolodiazhnyi, O. I.; Kukhar, V. P.; Kolodiazhna, A. O. Asymmetric catalysis as a method for the synthesis of chiral organophosphorus compounds. Tetrahedron: Asymmetry 2014, 25, 865-922. (c) Dutartre, M; Bayardon, J.; Jugé, S. Applications and stereoselective syntheses of P-chirogenic phosphorus compounds. Chem. Soc. Rev. 2016, 45, 5771-5794. 
(5) (a) Takizawa, S.; Rémond, E.; Arteaga Arteaga, F.; Yoshida, Y.; Sridharan, V.; Bayardon, J.; Jugé, S.; Sasai, H. P-chirogenic organocatalysts: application to the azaMorita-Baylis-Hillman (aza-MBH) reaction of ketimines. Chem. Commun. 2013, 49, 83928394. (b) Rémond, E.; Jugé, S. P-chirogenic organophosphorus acid-bases in asymmetric organocatalysis. Chemistry ToDay 2014, 32, 49-55. (c) Uraguchi, D.; Sasaki, H.; Kimura, Y.; Ito, T.; Ooi, T. Molecular design, synthesis, and asymmetric catalysis of a hexacoordinated chiral phosphate ion. J. Am. Chem. Soc. 2018, 140, 2765-2768. (d) Uraguchi, D.; Shibazaki, R.; Tanaka, N.; Yamada, K.; Yoshioka, K; Ooi, T. Catalystenabled site-divergent stereoselective Michael reactions: overriding intrinsic reactivity of enynyl carbonyl acceptors. Angew. Chem. Int. Ed. 2018, 57, 4732-4736. (e) Uraguchi, D.; Yamada, K.; Sato, M.; Ooi, T. Catalyst-directed guidance of sulfur-substituted enediolates to stereoselective carbon-carbon bond formation with aldehydes. J. Am. Chem. Soc. 2018, 140, 5110-5117. (f) Aillard, P.; Gicquel, M.; Yavari, K.; Retailleau, P.; Voituriez, A.; Marinetti, A. Tuning the structure of phosphahelicenes for targeted applications in enantioselective phosphine organocatalysis. Eur. J. Org. Chem. 2018, 5853-5860. (g) Yang, X.-H.; Li, J.-P.; Wang, D.-C.; Xie, M.-S.; Qu, G.-R.; Guo H.-M. Enantioselective dearomative [3+2] cycloaddition of 2-nitrobenzofurans with aldehyde-derived MoritaBaylis-Hillman carbonates. Chem. Commun. 2019, 55, 9144-9147. 
(6) (a) Agbossou, F.; Carpentier, J.-F.; Hapiot, F.; Suisse, I.; Mortreux, A. The aminophosphine-phosphinites and related ligands: synthesis, coordination chemistry and enantioselective catalysis. Coord. Chem. Rev. 1998, 178-180, 1615-1645. (b) AgbossouNiedercorn, F.; Suisse, I. Chiral aminophosphine phosphinite ligands and related auxiliaries. Recent advances in their design, coordination chemistry, and use in enantioselective catalysis. Coord. Chem. Rev. 2003, 242, 145-158. (c) Agbossou, F. Chiral Aminophosphine-Phosphinites (AMPP) in Phosphorus Ligands in Asymmetric Catalysis: Synthesis and Applications, Börner, A., Ed.; Wiley-VCH: Weinheim, Germany, 2008; Vol 2, pp 477-505.

(7) (a) Buono, G.; Siv, C.; Peiffer, G.; Triantaphyldes, C.; Denis, P.; Mortreux, A.; Petit, F. Threophos: A new chiral aminophosphine phosphinite (AMPP) ligand highly efficient in asymmetric hydrovinylation of cyclohexa-1,3-diene catalyzed by Nickel complexes. J. Org. Chem. 1985, 50, 1782-1784. (b) Pardigon, O.; Buono, G. Enantioselective synthesis of deltacyclenes using a [Col $2: \mathrm{Zn}]$ catalytic system. Tetrahedron: Asymmetry 1993, 4, 19771980. (c) Pardigon, O.; Tenaglia, A.; Buono, G. Enantioselective syntheses of monofunctionalized deltacyclenes using a $\left[\mathrm{Col}_{2}: \mathrm{Zn}\right]$ catalytic system. J. Org. Chem. 1995, 60, 1868-1871. (d) Krause, H. W.; Schmidt, U.; Taudien, S.; Costisella, B.; Michalik, M. Aminophosphine phosphinites of propranolol analogues as ligands for Rh-catalyzed 
asymmetric hydrogenation. J. Mol. Cat. A 1995, 104, 147-157. (e) Lou, R.; Mi, A.; Jiang, Y.; Qin, Y.; Li, Z.; Fu, F.; Chan, A. S. C. Aminophosphine phosphinites derived from chiral 1,2-diphenyl-2-aminoethanols: synthesis and application in rhodium-catalyzed asymmetric hydrogenation of dehydroamino acid derivatives. Tetrahedron 2000, 56, 5857-5863. (f) Xie, Y.; Lou, R.; Li, Z.; Mi, A.; Jiang, Y. DPAMPP in catalytic asymmetric reactions: enantioselective synthesis of L-homophenylalanine. Tetrahedron: Asymmetry 2000, 11, 1487-1494. (g) Pasquier, C.; Naili, S.; Mortreux, A.; Agbossou, F.; Pélinski, L.; Brocard, J.; Eilers, J.; Reiners, I.; Peper, V.; Martens, Free and $\mathrm{Cr}(\mathrm{CO})_{3}$-complexed aminophosphine phosphinite ligands for highly enantioselective hydrogenation of $\alpha$-functionalized ketones.

J. Organometallics 2000, 19, 5723-5732. (h) Turcry, V.; Pasquier, C.; AgbossouNiedercorn, F. Aminophosphine phosphinite (AMPP) and enantioselective hydrogenation of ketones: further developments. C.R. Chimie 2003, 6, 179-184. (i) Dubrovina, N. V.; Taranov, V. I.; Kadyrova, Z.; Monsees, A.; Börner, A. Versatile synthesis of chiral aminophosphine phosphinite (AMPPs) as ligands for enantioselective hydrogenation. Synthesis 2004, 2047-2051.

(8) (a) Petit, M.; Mortreux, A.; Petit, F.; Buono, G.; Peiffer, G. Préparation d'aminophosphine-phosphinites chiraux. Applications en catalyse homogène asymétrique.

New. J. Chem. 1983, 7, 593-596. (b) Pracejus, G.; Pracejus, H. Chiral O,N- 
bis(diphenylphosphino)aminoalkanols as ligands for enantioselective metal complex hydrogenation catalysts. J. Mol. Cat. 1984, 24, 227-230. (c) Mutez, S.; Mortreux, A.; Petit, F. Asymmetric hydroformylation of styrene on aminophosphinephosphinites modified platinium catalysts. Tetrahedron Lett. 1988, 29, 1911-1914. (d) Potier, Y.; Mortreux, A.; Petit, F. Utilisation des ligands aminophosphinephosphinites en hydroformylation catalysée par le rhodium: amélioration de l'énantioselectivité par synthèse selective des hydrures $\mathrm{RhH}(\mathrm{CO})_{2} \mathrm{~L}^{*}$. J. Organomet. Chem. 1989, 370, 333-342. (e) Kokel, N.; Mortreux, A.; Petit, F. Asymmetric hydrosilylation of a Schiff base of acetophenone catalyzed by Rh(AMPP) complexes. J. Mol. Cat. 1989, 57, L5-L7. (f) Gong, L.; Chen, G.; Mi, A.: Jiang, Y.; Fu, F.; Cui, X.; Chan, A. S. C. Chiral aminophosphine phosphinite-palladium catalysts in asymmetric allylic alkylations. Tetrahedron: Asymmetry 2000, 11, 4297-4302.

(9) (a) Moulin, D.; Darcel, C.; Jugé, S. Versatile synthesis of P-chiral (ephedrine) AMPP ligand via their borane complexes. Structural consequences in Rh-catalyzed hydrogenation of methyl $\alpha$-acetamidocinnamate. Tetrahedron: Asymmetry 1999, 10, 4729-4743. (b) Darcel, C.; Moulin, D.; Henry, J.-C.; Lagrelette, M.; Richard, P.; Harvey, P. D.; Jugé, S. Modular P-chirogenic aminophosphane-phosphinite ligands for Rh-catalyzed asymmetric hydrogenation: A new model for prediction of enantioselectivity. Eur. J. Org. Chem. 2007, 2078-2090. (c) Khiri, N.; Bertrand, E.; Ondel-Eymin, M.-J.; Rousselin, Y.; Bayardon, J.; 
Harvet, P. D.; Jugé, S. Enantioselective hydrogenation catalysis aided by a $\sigma$-bonded calix[4]arene to a P-chirogenic aminophosphane phosphinite rhodium complex. Organometallics 2010, 29, 3622-3631.

(10) (a) Ewalds, R.; Eggeling, E. B.; Hewat, A. C.; Kramer, P. C. J.; van Leeuwen, P. W. N. M.; Vogt, D. Application of P-stereogenic aminophosphine phosphinite ligands in asymmetric hydroformylation. Chem. Eur. J. 2000, 6, 1496-1504. (b) Carbo, J.J.; Lledos, A.; Vogt, D.; Bo, C. Origin of stereoinduction by chiral aminophosphane phosphinite ligands in enantioselective catalysisi: asymmetric hydroformylation. Chem. Eur. J. 2006, $12,1457-1467$

(11) (a) Bertrand, C.; Humbel, S.; Bauduin, C.; Darcel, C.; Jugé, S. Configurational stability of chlorophosphines. Inorg. Chem. 2003, 42, 420-427. (b) Bauduin, C.; Moulin, D.; Kaloun, E. B.; Darcel, C.; Jugé, S. Highly enantiomerically enriched chlorophosphine boranes: synthesis and applications as P-chirogenic electrophilic blocks. J. Org. Chem. 2003, 4293-4301.

(12) Jaillet, A.; Bayardon, J.; Jugé, S., C-bulky P-chirogenic organophosphorus compounds. Intern. Patent. EP 18305304 (2018 March 20th); PCT/EP2019/056965 (2019 March $\left.20^{\text {th }}\right)$; WO 2019/180084 (2019 Sept. 26 $\left.6^{\text {th }}\right)$. 
(13) For a representative example of diastereoselective synthesis with dynamic resolution of binaphtylithium reagent, see: Clayden, J; Kubinski, P. M.; Sammicelli, F.; Heliwell, M.; Diorazio, L. Sulfoxides as 'traceless' resolving agents for the synthesis of atropoisomers by dynamic or classical resolution. Tetrahedron 2004, 60, 4387-4397.

(14) den Heeten, R.; Swennenhuis, B. H. G.; van Leeuwen, P. W. N. M.; de Vries, J. G.; Kamer, P. C. J. Parallel synthesis and screening of polymer-supported phosphorusstereogenic aminophosphane-phosphite and -phosphinite ligands. Angew. Chem. Int. Ed. $2008,47,6602-6605$.

(15) Chaux, F.; Frynas, S.; Laureano, H.; Salomon, C.; Morata, G.; Auclair, M.-L.; Stephan, M.; Merdès, R.; Richard, P.; Eymin, M.-J.; Henry, J.-C.; Bayardon, J.; Darcel, C.; Jugé, S. Enantiodivergent synthesis of P-chirogenic phosphines. C.R. Chimie 2010, 13, 1213-1226.

(16) (a) Trost, B. M.; Crawley, M. L. Asymmetric transition-metal-catalyzed allylic alkylations: Applications in total synthesis. Chem. Rev. 2003, 103, 2921-2943. (b) Trost, B. M.; Zhang, T.; Sieber, J. D. Catalytic asymmetric allylic alkylation employing heteroatom nucleophiles: a powerful method for C-X bond formation. Chem. Sci. 2010, 1, 427-440. (c) Guerrero Rios, I.; Rosas-Hernandez, A.; Martin, E. Recent advances in the application of chiral phosphine ligands in Pd-catalysed asymmetric allylic alkylation. Molecules 2011, 16, 
970-1010. (d) Trost, B. M. Pd- and Mo-catalyzed asymmetric allylic alkylation. Org. Process Res. Dev. 2012, 16, 185-194. (e) Ding, C.-H.; Hou, X. L. Nucleophiles with Allyl Metal Complexes in Comprehesive Organic Synthesis I/, Knochel, P., Molander, G. A. Eds, 2014, Vol. 4, pp 649-694, Elsevier. (f) Trost, B. M.; Schultz, J. E. Palladium-catalyzed asymmetric allylic alkylation strategies for the synthesis of acyclic tetrasubstituted stereocenters. Synthesis 2019, 1-30.

(17) For recent applications of palladium-catalyzed asymmetric allylic alkylation in organic synthesis, see: (a) Fournier, J.; Lozano, O.; Menozzi, C.; Arseniyadis, S.; Cossy, J. Palladium-catalyzed asymmetric allylic alkylation of cyclic dienol carbonates: efficient route to enantioenriched $\gamma$-butenolides bearing an all-carbon $\alpha$-quaternary stereogenic center. Angew. Chem. Int. Ed. 2013, 52, 1257-1261. (b) Lei, B.-L.; Zhang, Q.-S.; Yu, W.-H.; Ding, Q.-P.; Ding, C.-H.; Hou, X.-L. Kinetic resolution of 2-substituted 2,3-dihydro-4-pyridones by palladium-catalyzed asymmetric allylic alkylation: catalytic asymmetric total synthesis of Indolizidine (-)-209I. Org. Lett. 2014, 16, 1944-1947. (c) Jiang, Y.-J.; Zhang, G.-P.; Huang, J.-Q.; Chen, D.; Ding, C.-H.; Hou, X.-L. Palladium-catalyzed asymmetric allylic alkylation of alkyl-substituted allyl reagents with acyclic amides. Org. Lett. 2017, 19, 5932-5935. (d) de Oliveira, M.N.; Arseniyadis, S.; Cossy, J. Palladium-catalyzed asymmetric allylic alkylation of 4-substituted isoxazolidin-5-ones: Straightforward access to $\beta^{2,2}$-amino acids. Chem. 
Eur. J. 2018, 24, 4810-4814. (e) Trost, B.M.; Bai, W.-J.; Hohn, C.; Bai, Y.; Cregg, J.J.

Palladium-catalyzed asymmetric allylic alkylation of 3 -substituted 1 H-indoles and tryptophan derivatives with vinylcyclopropanes. J. Am. Chem. Soc. 2018, 140, 6710-6717.

(f) Song, T.; Arseniyadis, S.; Cossy, J. Asymmetric synthesis of a-quaternary $\mathrm{Y}$-lactams through palladium-catalyzed asymmetric allylic alkylation. Org. Lett. 2019, 21, 603-607.

(18) Nettekoven, U.; Widhalm, M.; Kalchhauser, H.; Kamer, P. C. J.; van Leeuven, P. W. N. M.; Lutz, M.; Spek, A. L. Steric and electronic ligand perturbations in catalysis: asymmetric allylic substitution reactions using $C_{2}$-symmetrical phosphorus-chiral (bi)ferrocenyl donors. J. Org. Chem. 2001, 66, 759-770.

(19) Oohara, N.; Katagiri, K.; Imamoto, T. A novel P-chirogenic phosphine ligand, (S,S)1,2-bis-[(ferrocenyl)methylphosphino]ethane: synthesis and use in rhodium-catalyzed asymmetric hydrogenation and palladium-catalyzed asymmetric allylic alkylation. Tetrahedron: Asymmetry 2003, 14, 2171-2175.

(20) (a) Tsuruta, H.; Imamoto, T. P-Chirogenic monodentate phosphine ligands bearing 2-biphenyl group. Synlett 2001, 999-1002. (b) Imamoto, T.; Nishimura, M.; Koide, A.; Yoshida, K. t-Bu-QuinoxP* ligand: Applications in asymmetric Pd-catalyzed allylic substitution and Ru-catalyzed hydrogenation. J. Org. Chem. 2007, 72, 7413-7416. 
(21) Bayardon, J.; Maronnat, M.; Langlois, A.; Rousselin, Y.; Harvey, P. D.; Jugé, S. Modular P-chirogenic phosphine-sulfide ligands: Clear evidence for both electronic effect and P-chirality driving enantioselectivity in Palladium-catalyzed allylations. Organometallics $2015,34,4340-4358$.

(22) (a) Zhang, K.; Peng, Q.; Hou, X.-L.; Wu, Y.-D. Highly enantioselective palladiumcatalyzed alkylation of acyclic amides. Angew. Chem. Int. Ed. 2008, 47, 1741-1744. (b) Lei, B.-L.; Ding, C.-H.; Yang, X.-F.; Wan, X.-L.; Hou, X.-L. Kinetic resolution of 2,3-dihydro-2substituted 4-quinolones by palladium-catalyzed asymmetric allylic alkylation. J. Am. Chem. Soc. 2009, 131, 18250-18251. (c) Yu, W.-H.; Yang, X.-F.; Xu, C.-F.; Ding, C.-H.; Hou, X.-L. Desymmetrization of bicyclo[3.n.1]-3-one derivatives by palladium-catalyzed asymmetric allylic alkylation. Org. Lett. 2013, 15, 3880-3883. (d) Yang, X.-F.; Yu, W.-H.; Ding, C.-H.; Ding, Q.-P.; Wan, S.-L.; Hou, X.-L.; Dai, L.-X.; Wang, P.-J. Palladiumcatalyzed regio-, diastereo-, and enantioselective allylation of nitroalkanes with monosubstituted allylic substrates. J. Org. Chem. 2013, 78, 6503-6509. (e) Bai, C.-H.; Liu, X.-Y.; Li, H.; Ding, C.-H.; Hou, X.-L. Tandem Thorpe reaction/palladium catalyzed asymmetric allylic alkylation: access to chiral $\beta$-enaminonitriles with excellent enantioselectivity. Chem. Asian J. 2017, 12, 212-215. 
(23) For a recent review on stereodivergent catalysis, see: Beletskaya, I. P.; Najera, C.;

Yus, M. Stereodivergent catalysis. Chem. Rev. 2018, 118, 5080-5200.

(24) Haquette, P.; Lebideau, F.; Dagorne, S.; Marrot, J.; Jaouen, G. A new optically pure half-sandwich $\mathrm{Cp}-\mathrm{Ru}$ diphosphine complex with a chiral metal centre, $(S)-\mathrm{Ru}\left(\eta^{5}-\mathrm{C}_{5} \mathrm{H}_{5}\right)$ $(\mathrm{EPHOS}) \mathrm{Cl} \quad$ EPHOS $\quad$ is $\quad(+)-(1 R, 2 S)-2-[($ diphenylphosphino $)$ methylamino $-1-$ phenylpropyldiphenyl phosphinite\} Acta Cryst. 2002, C58, m551-m552.

(25) (a) Cesarotti, E.; Grassi, M.; Prati, L., Demartin, F. Dynamic behaviour and X-ray analysis of chiral $\eta^{3}$-allylpalladium complexes. J. Organomet. Chem. 1989, 370, 407-419. (b) Cesarotti, E.; Grassi, M.; Prati, L.; Demartin, F. Nuclear Magnetic Resonance and Crystallographic Studies of Chiral $\eta^{3}$-Allyl Palladium(II) Complexes and Asymmetric Allylic Alkylation of Propen-2-yl Acetates. J. Chem. Soc., Dalton Trans. 1991, 2073-2082.

(26) For least influence of Fukui constants in Pd-catalyzed asymmetric allylic alkylation, see: Marinho, V. R.; Prates Ramalho, J. P.; Rodrigues, A. I.; Burke, A. J. A comparison of $(R, R)$-Me-DUPHOS and $(R, R)$ DUPHOS- $P r$ ligands in the $\mathrm{Pd}^{0}$-catalysed asymmetric allylic alkylation reaction: Stereochemical and kinetic considerations. Eur. J. Org. Chem. 2009, 6311-6317.

(27) (a) Mangas-Sanchez, J.; Busto, E.; Gotor-Fernandez, V.; Gotor, V. Straightforward synthesis of enantiopure 2,3-dihydrobenzofurans by a sequential stereoselective 
biotransformation and chemical intramolecular cyclization. Org. Lett. 2010, 12, 3498-3501.

(b) Reitz, A. B.; Baxter, E. W.; Codd, E. E.; Davis, C. B.; Jordan, A. D.; Maryanoff, B. E.; Maryanoff, C. A.; McDonnell, M. E.; Powell, E. T.; Renzi, M. J.; Schott, M. R.; Scott, M. K.; Shank, R. P.; Vaught, J. L. Orally active benzamide antipsychotic agents with affinity for dopamine $\mathrm{D}_{2}$, serotonin $5-\mathrm{HT}_{1 \mathrm{~A}}$, and adrenergic $\alpha_{1}$ receptors. J. Med. Chem. 1998, 41, 1997-2009. (c) Ukwitegetse, N.; Saris, P. J. G.; Sommer, J. R.; Haiges, R. M.; Djurovich, P. I.; Thompson, M. E. Tetra-aza-pentacenes by means of a one-pot Friedländer synthesis. Chem. Eur. J. 2019, 25, 1472-1475.

(28) Diemer, V.; Begaud, M.; Leroux, F. R.; Colobert, F. Regioselectivity in the aryne cross-coupling of aryllithiums with functionalized 1,2-dibromobenzenes. Eur. J. Org. Chem. $2011,341-354$

(29) (a) Maienza, F.; Wörle, M.; Steffanut, P.; Mezzetti, A.; Spindler, F. Ferrocenyl diphosphines containing stereogenic phosphorus atoms. Synthesis and application in the rhodium-catalyzed asymmetric hydrogenation. Organometallics 1999, 18, 1041-1049. (b) Nettekoven, U.; Kamer, P. C. J.; van Leeuven, P. W. N. M.; Widhalm, M.; Spek, A. L.; Lutz, M. Phosphorus-chiral analogues of 1,1'-bis(diphenylphosphino)ferrocene: asymmetric synthesis and application in highly enantioselective rhodium-catalyzed hydrogenation reactions. J. Org. Chem. 1999, 64, 3996-4004. 
(30) Colby, E. A.; Jamison, T. F. P-Chiral, monodentate ferrocenyl phosphines, novel ligands for asymmetric catalysis. J. Org. Chem. 2003, 68, 156-166.

(31) Holz, J.; Rumpel, K.; Spannenberg, A.; Paciello, R.; Jiao, H.; Börner, A. P-Chirogenic Xantphos Ligands and related ether diphosphines: Synthesis and application in rhodium-catalyzed asymmetric hydrogenation. ACS Catal. 2017, 7, 6162-6169.

(32) Rippert, A. J.; Linden, A.; Hansen, H.-J. Formation of diastereomerically pure oxazaphospholes and their reaction to chiral phosphane-borane adducts. Helv. Chim. Acta 2000, 83, 311-321.

(33) Bayardon, J.; Rousselin, Y.; Jugé, S. Designing P-chirogenic 1,2diphosphinobenzenes at both P-centers using P(III)-phosphinites. Org. Lett. 2016, 18, 2930-2933.

(34) Grabulosa, A.; Mannu, A.; Muller, G.; Calvet, T.; Font-Bardia, M. P-Stereogenic monophosphines in $\mathrm{Pd}$-catalyzed enantioselective hydrovinylation of styrene. J. Organomet. Chem. 2011, 696, 2338-2345. (b) Mohar, B.; Cusak, A.; Modec, B.; Stephan, M. P-Stereogenic phospholanes or phosphorinanes from o-biarylylphosphines: Two bridges not too far. J. Org. Chem. 2013, 78, 4665-4673. 
(35) Sprinz, J.; Helmchen, G. Phosphinoaryl- and phosphinoalkyloxazolines as new chiral ligands for enantioselective catalysis: Very high enantioselectivity in palladium catalyzed allylic substitutions. Tetrahedron Lett. 1993, 34, 1769-1772. 